\title{
Preparation of Simulated LBL Defects for Round Robin Experiment
}

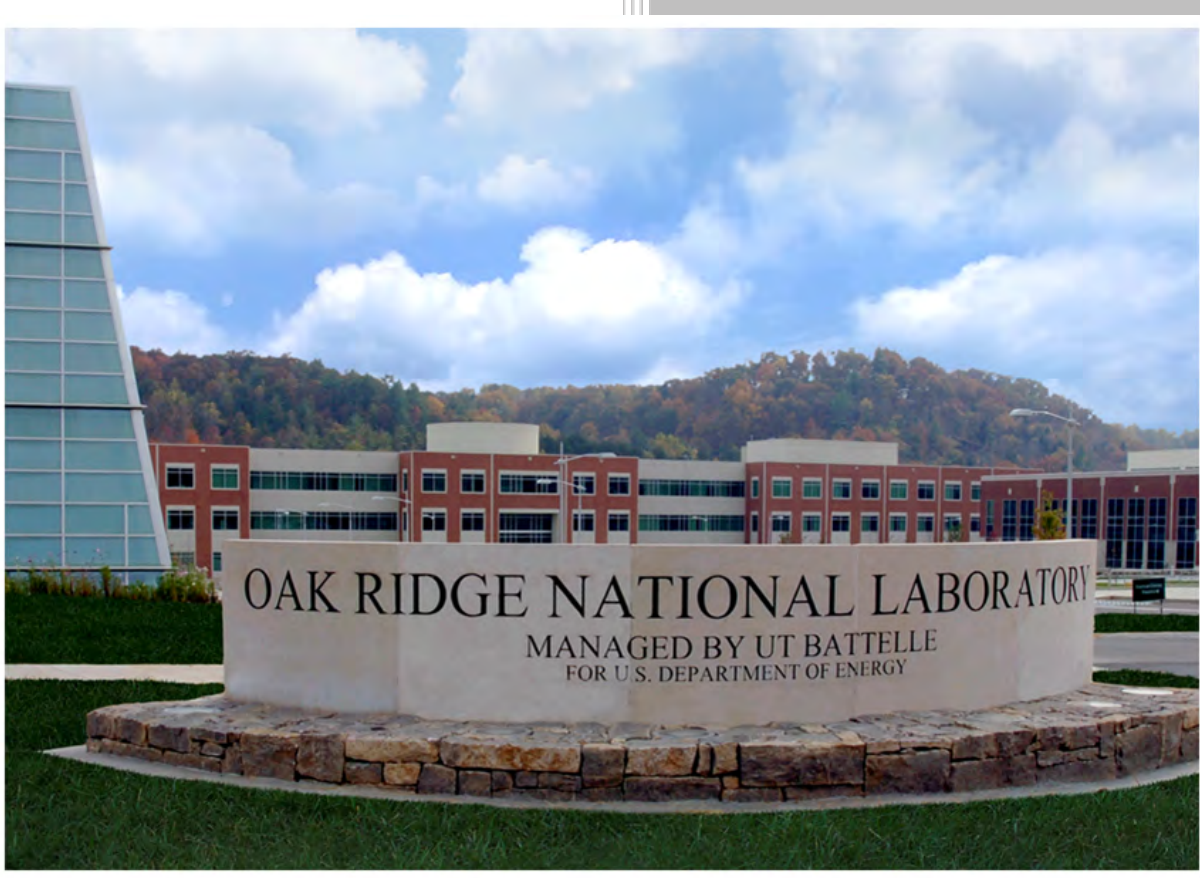

Approved for public release.

Distribution is unlimited.

Tyler J. Gerczak Charles A. Baldwin Grant Helmreich John D. Hunn Fred C. Montgomery

Revision 2, July 2016 


\title{
DOCUMENT AVAILABILITY
}

Reports produced after January 1, 1996, are generally available free via US Department of Energy (DOE) SciTech Connect.

Website http://www.osti.gov/scitech/

Reports produced before January 1, 1996, may be purchased by members of the public from the following source:

\author{
National Technical Information Service \\ 5285 Port Royal Road \\ Springfield, VA 22161 \\ Telephone 703-605-6000 (1-800-553-6847) \\ TDD 703-487-4639 \\ Fax 703-605-6900 \\ E-mail info@ntis.gov \\ Website http://www.ntis.gov/help/ordermethods.aspx
}

Reports are available to DOE employees, DOE contractors, Energy Technology Data Exchange representatives, and International Nuclear Information System representatives from the following source:

Office of Scientific and Technical Information

PO Box 62

Oak Ridge, TN 37831

Telephone 865-576-8401

Fax 865-576-5728

E-mail reports@osti.gov

Website http://www.osti.gov/contact.html

This report was prepared as an account of work sponsored by an agency of the United States Government. Neither the United States Government nor any agency thereof, nor any of their employees, makes any warranty, express or implied, or assumes any legal liability or responsibility for the accuracy, completeness, or usefulness of any information, apparatus, product, or process disclosed, or represents that its use would not infringe privately owned rights. Reference herein to any specific commercial product, process, or service by trade name, trademark, manufacturer, or otherwise, does not necessarily constitute or imply its endorsement, recommendation, or favoring by the United States Government or any agency thereof. The views and opinions of authors expressed herein do not necessarily state or reflect those of the United States Government or any agency thereof. 
Fusion and Materials for Nuclear Systems Division

\title{
PREPARATION OF SIMULATED LBL DEFECTS FOR ROUND ROBIN EXPERIMENT
}

\author{
Tyler J. Gerczak \\ Charles A. Baldwin \\ Grant Helmreich \\ John D. Hunn \\ Fred C. Montgomery \\ Revision 2 \\ Date Published: July 2016 \\ Work sponsored by \\ US DEPARTMENT OF ENERGY \\ Office of Nuclear Energy - Advanced Reactor Technologies \\ under the \\ Advanced Gas Reactor Fuel Development and Qualification Program \\ Prepared by \\ OAK RIDGE NATIONAL LABORATORY \\ Oak Ridge, TN 37831-6283 \\ managed by \\ UT-BATTELLE, LLC \\ for the \\ US DEPARTMENT OF ENERGY \\ under contract DE-AC05-00OR22725
}





\section{CONTENTS}

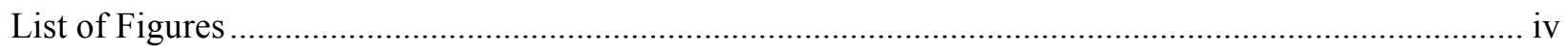

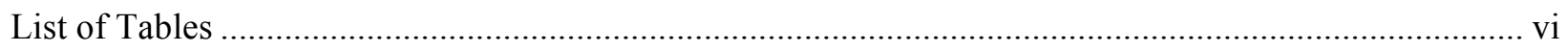

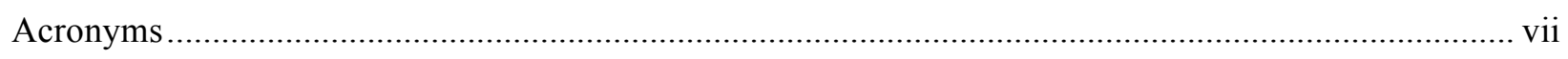

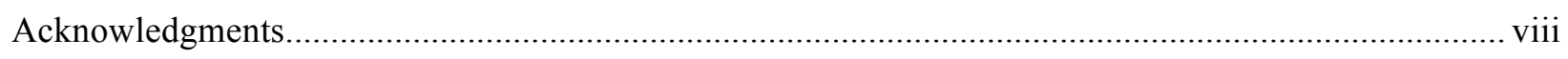

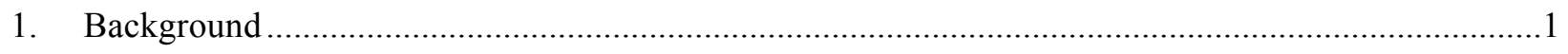

2. Overview of Leach-Burn-Leach Round Robin...............................................................................

3. ORNL DUO $\mathrm{D}_{2}$-TRISO Particles Used to Make Simulated Defects ...................................................6

4. Fabrication of Simulated Pre-Burn Leach Defects ....................................................................... 7

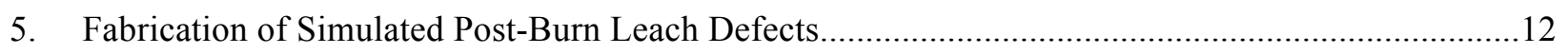

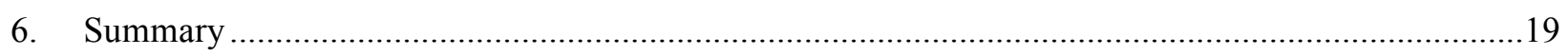

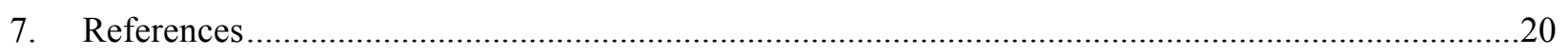

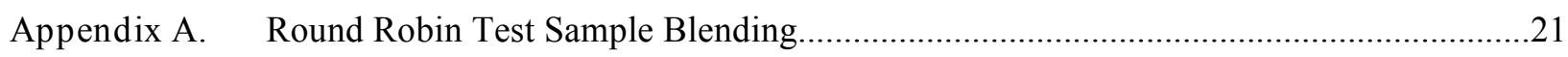

Appendix B. Example of Excel Data Report Form for Round Robin Experiment .............................22

Appendix C. Optical Images of Simulated Pre-Burn Leach Defects in DUN500S-10A Particles

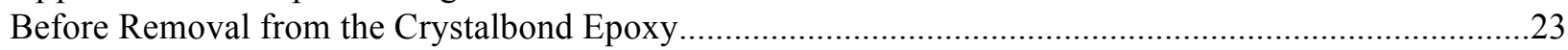

Appendix D. X-Ray Tomographs of Simulated Pre-Burn Leach Defects in DUN500S-10A Particles After Removal from the Crystalbond Epoxy ....................................................................28

Appendix E. SEM Images and X-ray Radiographs of Simulated Post-Burn Leach Defects in

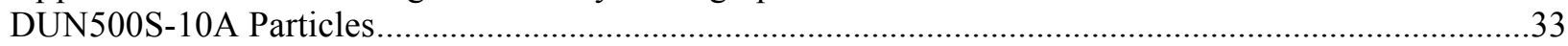




\section{LIST OF FIGURES}

Figure 1. Overview of the AGR-2 TRISO fuel form: (a) cross-section of an as-fabricated AGR-2 $\mathrm{UO}_{2}$-TRISO particle showing the particle construction, and (b) x-ray radiograph of an as-fabricated AGR-2 $\mathrm{UO}_{2}$ fuel compact showing the particle distribution in the graphite matrix, where the black circles are projections of the kernels. 1

Figure 2. Flow chart of the LBL process, which demonstrates the individual steps in the analysis and determination of particle defect properties.

Figure 3. High-resolution x-ray tomographs showing defective TRISO particles: (a) an example of a pre-burn leach defect that had an exposed kernel due to a fracture propagating from the OPyC through to the kernel, and (b) an example of a post-burn leach defect that had a defective-SiC layer due to a large soot inclusion that allowed the IPyC and buffer to be burned out. The kernels in both particles were removed during LBL.

Figure 4. Impact fracture apparatus showing (a) an overview of the system with markings for drop height in 1-cm increments and (b) schematic of impact process; identifying how ram is in contact with TRISO particles partially encapsulated in Crystalbond and showing the process of dropping the weight at a defined height and transferring impact force to particle through ram..........7

Figure 5. Optical images of impact-fractured particles embedded in Crystalbond after dropping a 75-g weight $1 \mathrm{~cm}$ : (a) particle with radial fractures extending into Crystalbond, (b) particle with large visible fractures in OPyC layer, and (c) particle with catastrophic failure of TRISO layers. ......8

Figure 6. Optical images of impact-fractured particle after dropping a 75-g weight $1 \mathrm{~cm}$ : (a) particle embedded in Crystalbond with radial fractures extending into Crystalbond, and (b) polished cross section approximately normal to the impact site showing radial fracture traversing the TRISO layers.

Figure 7. Example of results from a 4.90-g weight dropped $2.5 \mathrm{~cm}$ : (a) optical image showing faint radial fractures in $\mathrm{OPyC}$ and Crystalbond, and (b) x-ray tomograph normal to impact direction showing cracks in TRISO layers.

Figure 8. Three-dimensional x-ray tomography visualization of a particle's SiC surface after impact fracturing with a 4.90-g weight dropped $2.5 \mathrm{~cm}$ : (a) view normal to the impact fracture showing radial fracture pattern, and (b) view rotated approximately 90 degrees to impact fracture site showing termination of one of the radial fractures.

Figure 9. (a) Optical image of GIF-17 showing the OPyC and Crystalbond fracture after impact, and (b) x-ray tomograph showing the fracture propagating through the TRISO layers.

Figure 10. X-ray radiograph of GIF-48 showing complete absence of the $\mathrm{DUO}_{2}$ kernel after pre-burn leach.

Figure 11. X-ray radiographs of DUN500S-10A particles with differing LBL behaviors showing a closeup of the FIB-fabricated through-layer defects: (a) particle with a simulated-defect penetrating $23-\mu \mathrm{m}$ deep into the IPyC layer, where the equivalent of $97 \%$ of an average kernel's total uranium content was dissolved in the post-burn leach; and (b) particle with a simulated-defect penetrating $28-\mu \mathrm{m}$ deep into the IPyC layer, where only $7 \%$ of an average kernel's total uranium content was dissolved in the post-burn leach.

Figure 12. Secondary-electron SEM micrographs of craters produced with a 25 - $\mu \mathrm{m}$-diameter raster pattern showing the initial SiC surface, the sidewall, and the bottom of the craters. Both features were produced with a two-step milling process utilizing a $30-\mathrm{kV}, 50-\mathrm{nA} \mathrm{Ga}^{+}$ion beam followed by a $30-\mathrm{kV}, 15-\mathrm{nA} \mathrm{Ga}{ }^{+}$ion beam: (a) $33 \mathrm{~min}$ at $50 \mathrm{nA}$ followed by $10 \mathrm{~min}$ at $15 \mathrm{nA}$, and (b) $38 \mathrm{~min}$ at $50 \mathrm{nA}$ followed by $10 \mathrm{~min}$ at $15 \mathrm{nA}$.

Figure 13. Secondary-electron SEM micrographs of a crater showing (a) the section of cleaned sidewall, and (b) a close up of the transition from $\mathrm{SiC}$ to IPyC confirming breakthrough into the IPyC layer. 
Figure 14. X-ray radiographs showing cross sections of the FIB-milled craters produced in the two particles shown in Figure 12: (a) particle with smooth crater bottom and (b) particle with mottled crater bottom (inset shows a close up of each feature).

Figure 15. X-ray radiograph of the particles presented in Figure 12 after heating in air at $750^{\circ} \mathrm{C}$ for 60 hours: (a) particle with smooth crater bottom and (b) particle with mottled crater bottom.

Figure 16. Two-part confirmation of acceptable microstructure for a simulated post-burn leach defect consisting of (a) secondary-electron SEM micrograph of the crater showing a mottled bottom with Pt marker, and (b) x-ray radiograph of the crater cross section indicating crater termination near the IPyC/SiC interface (inset shows close-up of the crater with platinum marker at the bottom).

Figure 17. X-ray tomograph of a particle with a simulated post-burn leach defect after pre-burn leaching, where bright regions in the buffer layer indicates the presence of uranium that was extracted from the kernel by nitric acid permeating the presumably intact IPyC layer.

Figure 18. X-ray tomograph of a particle with a simulated post-burn leach defect after post-burn leaching, where buffer and $\mathrm{IPyC}$ were oxidized and removed during the burn stage and the kernel was completely leached during the post-burn leach. 


\section{LIST OF TABLES}

Table 1. Description of GIF LBL round robin test samples with simulated defects 4

Table 2. Fluidized-bed CVD coating conditions and TRISO layer thicknesses of DUN500S-10A ............6

Table 3. Status of 50 particles from DUN500S-10A fabricated for inclusion in round robin experiment as simulated pre-burn leach defects using impact fracture method .................................11

Table 4. Results of LBL analysis on two test samples of five simulated post-burn leach defects .............16

Table 5. Status of 28 particles from DUN500S-10A fabricated for inclusion in round robin experiment as simulated post-burn leach defects using FIB-milling method.... 


\section{ACRONYMS}

AGR

Advanced Gas Reactor Fuel Development and Qualification Program

AGR-1

First AGR program irradiation experiment

AGR-2

CVD

$\mathrm{DUO}_{2}$

FIB

GIF

Second AGR program irradiation experiment

Chemical vapor deposition

Depleted uranium oxide

Focused-ion beam milling system

HTGR

INET

IPyC

Generation IV International Forum

KAERI

LBL

MTS

OPyC

ORNL

SEM

High temperature gas-cooled reactor

Institute of Nuclear and New Energy Technology (Tsinghua, China)

Inner pyrolytic carbon (layer)

Korea Atomic Energy Research Institute

Leach-burn-leach

Methyltrichlorosilane

Outer pyrolytic carbon (layer)

Oak Ridge National Laboratory

$\mathrm{SiC}$

Scanning electron microscope

TBD

Silicon carbide (layer)

TRISO Tristructural-isotropic (coated particles)

UCO Uranium carbide/uranium oxide (kernels)

$\mathrm{UO}_{2} \quad$ Uranium oxide (kernels)

VHTR Very-high temperature reactor 


\section{ACKNOWLEDGMENTS}

This work was sponsored by the U.S. Department of Energy, Office of Nuclear Energy, through the Idaho National Laboratory Advanced Reactor Technologies Technology Development Office as part of the Advanced Gas Reactor Fuel Development and Qualification Program. Analysis of leach solutions was provided by the Oak Ridge National Laboratory Nuclear Analytical Chemistry \& Isotopics Laboratory. 


\section{BACKGROUND}

Tristructural-isotropic (TRISO) coated particle fuel development and qualification is a current focus for advancing the deployment of select Generation IV reactor concepts, particularly for high-temperature gas-cooled reactor (HTGR) and very-high temperature reactor (VHTR) applications [Petti et al. 2010]. TRISO fuel and HTGR development programs are ongoing in many Generation IV International Forum (GIF) member states. A cooperative round robin experiment to benchmark the leach-burn-leach (LBL) process has been undertaken by the GIF VHTR Fuel and Fuel Cycle Project Management Board. Primary participants in this LBL round robin are China, South Korea, and the United States.

The TRISO-coated particle fuel design for most contemporary HTGRs is comprised of a uranium-bearing kernel containing either uranium oxide $\left(\mathrm{UO}_{2}\right)$ or a blend of uranium oxide and uranium carbide (UCO), surrounded by a porous carbon buffer layer, and successive isotropic layers of inner pyrolytic carbon (IPyC), chemical vapor deposited silicon carbide ( $\mathrm{SiC})$, and outer pyrolytic carbon (OPyC). Figure 1a shows a TRISO particle cross section identifying the general construction of the particle. Depending on the reactor design, individual TRISO particles are compacted into either a cylindrical shape (for the prismatic-core reactor) or spherical shape (for the pebble-bed reactor). The compacting is completed by first over-coating the particle in a resinated-graphite powder, followed by pressing of the over-coated particles into a final shape and firing them at elevated temperature to carbonize the resin. This yields a fully-refractory fuel form with individual TRISO particles dispersed throughout. The distribution of TRISO particles in a prismatic fuel compact from the AGR-2 irradiation campaign is shown in Figure $1 \mathrm{~b}$.
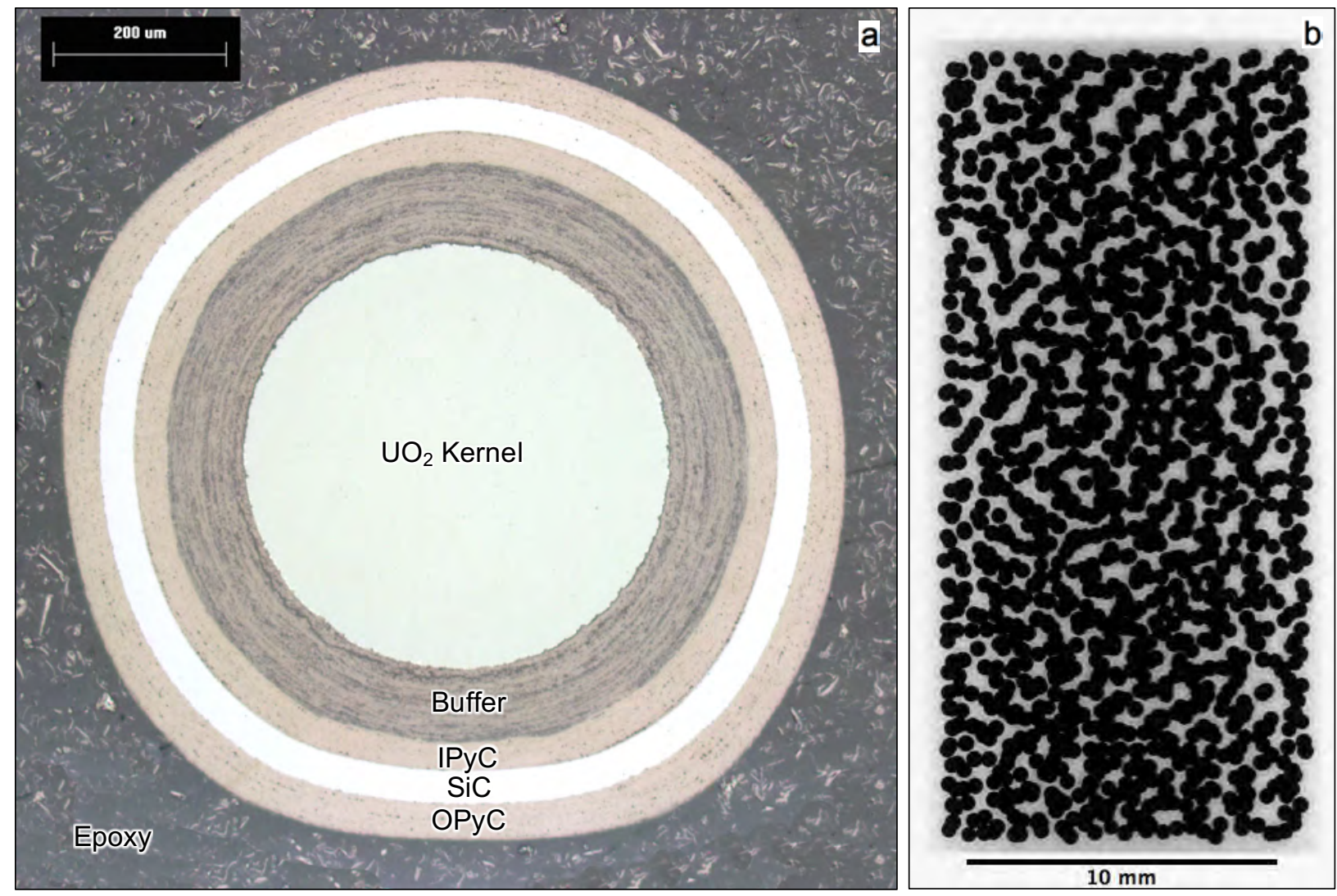

Figure 1. Overview of the AGR-2 TRISO fuel form: (a) cross-section of an as-fabricated AGR-2 UO $\mathrm{O}_{2}$-TRISO particle showing the particle construction, and (b) $x$-ray radiograph of an as-fabricated AGR-2 $\mathrm{UO}_{2}$ fuel compact showing the particle distribution in the graphite matrix, where the black circles are projections of the kernels. 
A critical characteristic of the TRISO fuel design is its ability to retain fission products. During reactor operation, the TRISO layers act as barriers to release of fission products not stabilized in the kernel. Each component of the TRISO particle and compact construction plays a unique role in retaining select fission products, and layer performance is often interrelated. The IPyC, SiC, and OPyC layers are barriers to the release of fission product gases such as $\mathrm{Kr}$ and $\mathrm{Xe}$. The $\mathrm{SiC}$ layer provides the primary barrier to release of metallic fission products not retained in the kernel, as transport across the $\mathrm{SiC}$ layer is rate limiting due to the greater permeability of the IPyC and OPyC layers to many metallic fission products. These attributes allow intact TRISO coatings to successfully retain most fission products released from the kernel, with the majority of released fission products during operation being due to defective, damaged, or failed coatings. This dominant release of fission products from compromised particles contributes to the overall source term for reactor accidents; causing safety and maintenance concerns and limiting the lifetime of the fuel. Under these considerations, an understanding of the nature and frequency of compromised particles is an important part of predicting the expected fission product release and ensuring safe and efficient operation. 


\section{OVERVIEW OF LEACH-BURN-LEACH ROUND ROBIN}

Leach-burn-leach is an analysis method used to determine several properties of TRISO-coated particles and fuel compacts. The two key defect populations measured by LBL are the number of exposed kernels (i.e., kernels not contained within any intact retentive layer, sometimes referred to as particles with defective or failed TRISO) and the number of particles with defective or failed SiC (i.e., particles whose $\mathrm{SiC}$ is not intact but have intact pyrocarbon still containing the kernels). These two defects lead to fission product release in reactor. The concentrations of impurities outside of intact SiC layers, especially the dispersed uranium (sometimes called the uranium contamination) are additional variable properties measured by LBL. A related method (burn-crush-burn-leach), which includes intentional destruction of the $\mathrm{SiC}$ and other coating layers, is used to measure uranium content in the particles or compacts.

The general LBL process at Oak Ridge National Laboratory (ORNL) includes three or four stages: electrolytic compact deconsolidation (unless analysis is performed on particles before compacting), preburn acid leaching, burning in air to remove exposed carbon, and post-burn acid leaching. A flow chart of the LBL process is presented in Figure 2. In the leaching stages, particles and matrix debris (if present) are leached in concentrated nitric acid. Leaching before or after the $750^{\circ} \mathrm{C}$ burn is performed with two separate 24-hour leaches and the leachates are measured to determine the quantity of uranium and various impurities that were leached. Exposed uranium detected at quantities below one-half of an average kernel's inventory is assumed to be related to uranium contamination outside of intact $\mathrm{SiC}$, while higher values are used to enumerate leached kernels. Uranium from exposed-kernel defects is detected in the pre-burn leach; an example of an exposed-kernel defect is a particle with an impact fracture that propagated from the OPyC through to the kernel area. Uranium from particles with a defective SiC layer is detected in the post-burn leach; an example of this type of defect is a TRISO fuel particle with a porous $\mathrm{SiC}$ layer but at least one intact pyrocarbon layer (IPyC or OPyC), such that the kernel is not exposed to acid leaching until after the intact pyrocarbon layer is burned away. SiC defects without a protective pyrocarbon layer are counted as exposed-kernel defects. Figure 3 shows examples of particles with preburn and post-burn leach defects. Additional detail on the ORNL LBL process can be found in various references [Hunn 2013, Hunn et al. 2013, Baldwin et al. 2014].

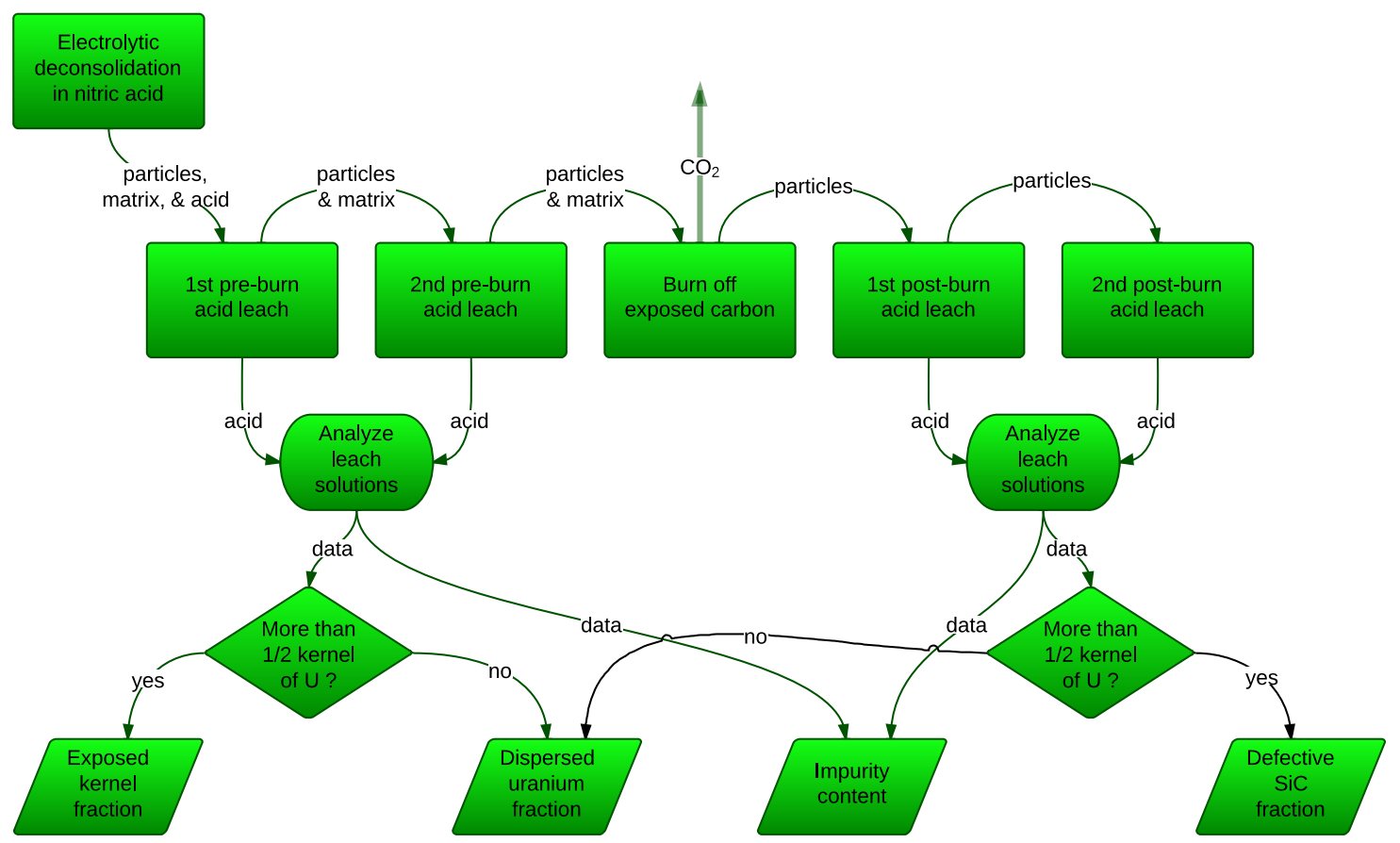

Figure 2. Flow chart of the LBL process, which demonstrates the individual steps in the analysis and determination of particle defect properties. 

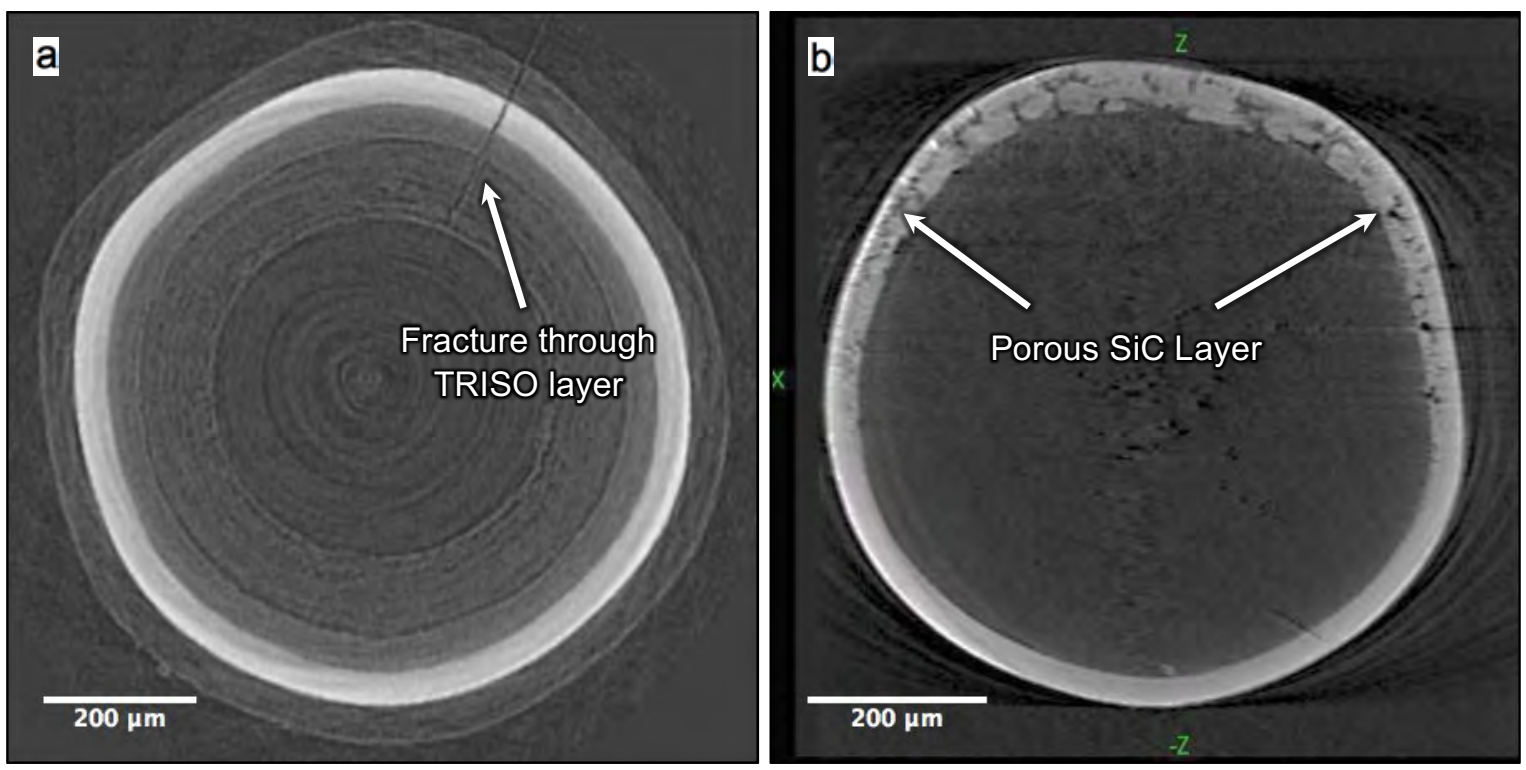

Figure 3. High-resolution x-ray tomographs showing defective TRISO particles: (a) an example of a pre-burn leach defect that had an exposed kernel due to a fracture propagating from the OPyC through to the kernel, and (b) an example of a post-burn leach defect that had a defective-SiC layer due to a large soot inclusion that allowed the IPyC and buffer to be burned out. The kernels in both particles were removed during LBL.

The motivation of the GIF LBL-benchmarking round robin experiment is to show consistency in LBL analysis results among the participating members and potentially understand the influence of LBL process variations on the accurate determination of the measured fuel properties. This will be accomplished through a systematic study of test samples of representative TRISO particles and test samples with known simulated defect populations that will be distributed to each participating GIF member organization for analysis. The research organizations participating in this study are ORNL, the Chinese Institute of Nuclear and New Energy Technology (INET), and the Korean Atomic Energy Research Institute (KAERI). Samples of representative TRISO particles will consist of riffled sublots of depleted uranium oxide $\left(\mathrm{DUO}_{2}\right)$-TRISO particles from a single, large ( 3-million particle) parent lot (provided by INET). Samples with known numbers of simulated LBL-defect particles containing $\mathrm{DUO}_{2}$ kernels will be analyzed separately (provided by ORNL). The remainder of this report focuses exclusively on proposed and completed work involving these round robin test samples with simulated defects.

To accomplish the proposed round robin experiment, a known number of $\mathrm{DUO}_{2}$-TRISO particles with simulated pre-burn leach or post-burn leach defects will be added to samples of surrogate $\mathrm{ZrO}_{2}$-TRISO particles. Table 1 shows the eight individual test samples to be prepared for each participant. A total of 21 DUO $_{2}$-TRISO particles with simulated pre-burn leach defects and $21 \mathrm{DUO}_{2}$-TRISO particles with simulated post-burn leach defects are required for the round robin experiment.

Table 1. Description of GIF LBL round robin test samples with simulated defects

\begin{tabular}{|c|c|c|c|}
\hline $\begin{array}{c}\text { Test } \\
\text { sample }\end{array}$ & $\begin{array}{l}\text { Number of simulated } \\
\text { pre-burn leach defect } \\
\text { DUO2-TRISO particles }\end{array}$ & $\begin{array}{l}\text { Number of simulated } \\
\text { post-burn leach defect } \\
\text { DUO2-TRISO particles }\end{array}$ & $\begin{array}{c}\text { Number of } \\
\mathrm{ZrO}_{2} \text {-TRISO } \\
\text { particles }\end{array}$ \\
\hline 1 & 0 & 0 & $>1000$ \\
\hline 2 & 1 & 0 & $>1000$ \\
\hline 3 & 2 & 0 & $>1000$ \\
\hline 4 & 4 & 0 & $>1000$ \\
\hline 5 & 0 & 1 & $>1000$ \\
\hline 6 & 0 & 2 & $>1000$ \\
\hline 7 & 0 & 4 & $>1000$ \\
\hline
\end{tabular}


The pre-burn leach and post-burn leach simulated-defect particles fabricated by ORNL will be shipped to INET and KAERI for LBL analysis. Test samples will contain particles with either pre-burn leach or post-burn leach simulated defects, as opposed to the original proposal where samples contained simulated defects of both types. Combination of both types of defects in a single sample is not recommended because of the possible data-analysis confusion that would occur if post-burn leach defects are prematurely leached before the burn. The defects will be seeded into each sample according to the distribution in Table 1. An ORNL team member will record the number and identity of the simulated-defect particles in each test sample and distribute the information after testing, so that the LBL analysis can be performed as a blind study. The specific defect-seeding scheme is presented in Appendix A.

In addition, ORNL will add variable but known amounts of a coal impurity standard (NIST SRM 1635a) to each sample. This will provide a round robin comparison of the impurity analysis performed during LBL. This standard reference material contains known quantities of $\mathrm{Ba}, \mathrm{Ru}$ and $\mathrm{Sr}$ as well as the transition metals $\mathrm{Co}, \mathrm{Cu}, \mathrm{Cr}, \mathrm{Fe}, \mathrm{Mn}$, and $\mathrm{Ni}$. Transition metal contamination in fuel compacts is a concern and included in the fuel specification because they may react with the $\mathrm{SiC}$ layer during irradiation.

Each participant will perform LBL analysis on their seven round robin test samples. Results will be reported in an Excel data report form that will be distributed to all participants prior to the initiation of the LBL testing. The form will clearly identify the information required for completion of the LBL analysis. An example of the Excel data report form is shown in Appendix B. After completion of the LBL analysis by all participants, the results will be sent to KAERI for statistical comparison and compilation into a final report. A summary report is also requested from each participating institution to describe their unique analysis procedures and results. 


\section{ORNL DUO ${ }_{2}$-TRISO PARTICLES USED TO MAKE SIMULATED DEFECTS}

The particles used for pre-burn and post-burn leach simulated-defect fabrication came from coating batch DUN500S-10A. These are DUO $_{2}$ kernels coated at ORNL with TRISO layers somewhat similar to those tested in the Advanced Gas Reactor Fuel Development and Qualification (AGR) Program first irradiation experiment (AGR-1). The kernels were fabricated at ORNL by the internal gelation technique and have an average diameter of $519 \pm 12 \mu \mathrm{m}$ and an average density of $10.7 \pm 0.3 \mathrm{~g} / \mathrm{cm}^{3}$. The deposition of the TRISO layers was carried out as an uninterrupted process using a laboratory-scale, fluidized-bed chemical vapor deposition (CVD) furnace with a 50-mm inner diameter conical chamber. The layer properties and select deposition parameters are listed in Table 2 [Lowden and McLaughlin 2004].

Table 2. Fluidized-bed CVD coating conditions and TRISO layer thicknesses of DUN500S-10A

\begin{tabular}{ccccc}
\hline Layer & Precursor gas & $\begin{array}{c}\text { Deposition temperature } \\
\left({ }^{\circ} \mathbf{C}\right)\end{array}$ & $\begin{array}{c}\text { Layer thickness } \\
(\boldsymbol{\mu m})\end{array}$ & $\begin{array}{c}\text { Density } \\
\left(\mathbf{g} / \mathbf{c m}^{\mathbf{3}}\right)\end{array}$ \\
\hline $\mathrm{Buffer}$ & $\mathrm{Ar}+\mathrm{C}_{2} \mathrm{H}_{2}$ & 1300 & $101 \pm 9$ & - \\
$\mathrm{IPyC}$ & $\mathrm{Ar}+\mathrm{C}_{2} \mathrm{H}_{2}+\mathrm{C}_{3} \mathrm{H}_{6}$ & 1300 & $49 \pm 4$ & - \\
$\mathrm{SiC}$ & $\mathrm{H}_{2}+\mathrm{MTS}$ & 1510 & $35.5 \pm 1.4$ & $3.205 \pm 0.001$ \\
$\mathrm{OPyC}$ & $\mathrm{Ar}+\mathrm{C}_{2} \mathrm{H}_{2}+\mathrm{C}_{3} \mathrm{H}_{6}$ & 1300 & $46 \pm 3$ & $1.898 \pm 0.009$ \\
\hline
\end{tabular}

MTS = methyltrichlorosilane

Note that the deposition temperatures and layer thicknesses of DUN500S-10A differ from the process conditions and layer thicknesses of particles irradiation-tested under the AGR program.

Particles were randomly selected for the simulated-defect fabrication to limit bias. The following sections describe the development of the simulated-defect fabrication process and the analysis of the simulated-defect particles to confirm the nature of the defects. The values for average total uranium per $\mathrm{DUO}_{2}$-TRISO particle and average ${ }^{235} \mathrm{U}$ content are required for the LBL round robin testing, as indicated in the data form in Appendix B. These values have already been determined by burn-crush-burn-leach on three separate 5-g fuel batches, the average total uranium per $\mathrm{DUO}_{2}$-TRISO particle was $7.003 \times 10^{-4} \mathrm{~g}$ with a standard deviation of $1.7 \times 10^{-6} \mathrm{~g}$ and the average measured ${ }^{235} \mathrm{U}$ content was $2.17 \times 10^{-3} \mathrm{~g} \mathrm{~g}^{235} \mathrm{U} / \mathrm{gU}$ with a standard deviation of $3 \times 10^{-5} \mathrm{~g}^{235} \mathrm{U} / \mathrm{gU}$. 


\section{FABRICATION OF SIMULATED PRE-BURN LEACH DEFECTS}

Simulated pre-burn leach defects were sought which mimicked exposed-kernel defects similar to that shown in Figure 3. Defects of this type have been observed in as-fabricated fuel lots as a result of impactinduced brittle fracture of the TRISO layers during handling. As such, an effort was developed to manually fracture TRISO particles in a controlled manner to generate particles with an exposed kernel that could be used as simulated pre-burn leach defects. Through-layer cracks through all TRISO layers were successfully produced by subjecting particles to single-point impact.

The impact fracture apparatus used to fabricate the simulated pre-burn leach defects is shown in Figure 4. A small weight was dropped to strike a flat-tipped ram, which moved along a track vertically and normally positioned with respect to the particle holder plate. The particles to be fractured were secured on the aluminum plate with Crystalbond ${ }^{\mathrm{TM}} 509$ mounting adhesive such that a small area of each particle remained exposed. The Crystalbond held the particle in position and provided additional support during the impact event. The mass and drop height of the small weight were adjusted to control the impact force.
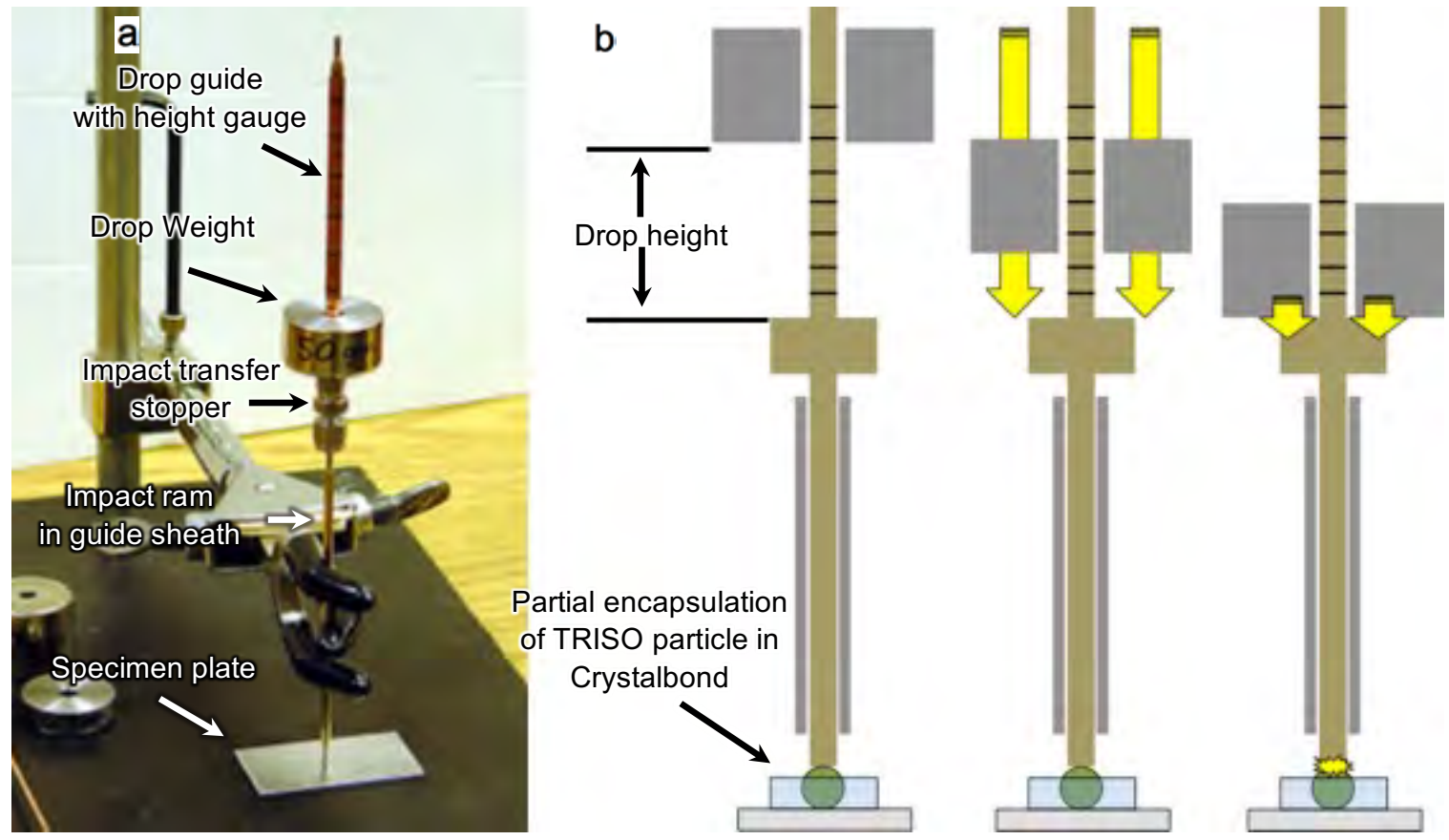

Figure 4. Impact fracture apparatus showing (a) an overview of the system with markings for drop height in 1-cm increments and (b) schematic of impact process; identifying how ram is in contact with TRISO particles partially encapsulated in Crystalbond and showing the process of dropping the weight at a defined height and transferring impact force to particle through ram.

A series of validation tests were performed on surrogate TRISO particles with $\mathrm{ZrO}_{2}$ kernels to identify the impact conditions necessary to achieve fine-scale, complete TRISO layer fracture and identify the indicators of a successfully fractured particle. Initial testing focused on a 75-g weight dropped from heights of 1-3 cm. Varied responses were observed, ranging from faint cracks moving radially out from the impact site to catastrophic failure; examples of the varied responses are shown in Figure 5. 

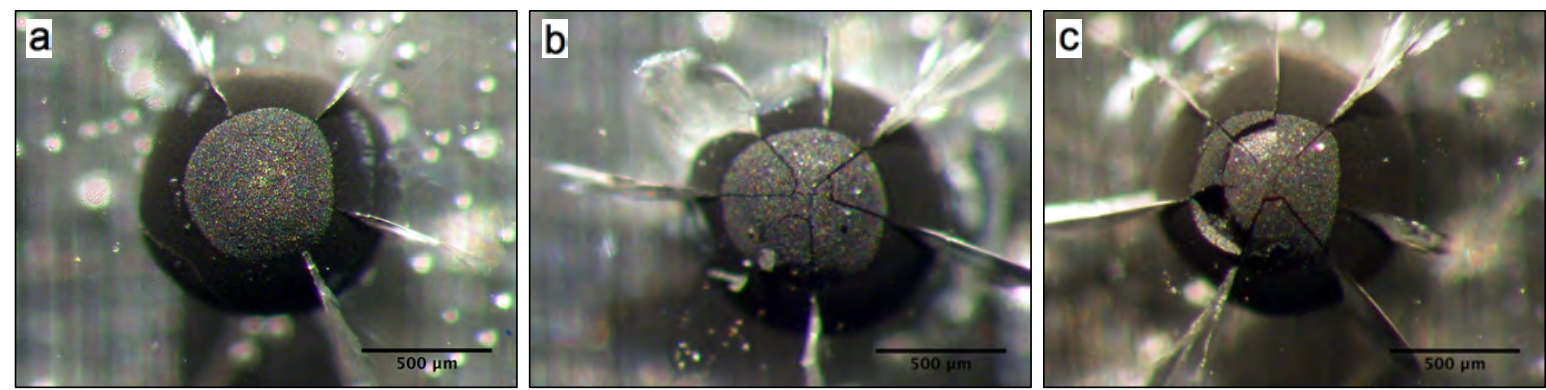

Figure 5. Optical images of impact-fractured particles embedded in Crystalbond after dropping a 75-g weight $1 \mathrm{~cm}$ : (a) particle with radial fractures extending into Crystalbond, (b) particle with large visible fractures in OPyC layer, and (c) particle with catastrophic failure of TRISO layers.

The particles with excessive visible fractures did not meet the fine-scale fracture criteria, however, particles with faint radial fractures radiating out into the Crystalbond were observed to correlate to fine-scale, complete TRISO layer failure; this correlation is shown in Figure 6 for a particle fractured with a 75-g weight dropped from $1 \mathrm{~cm}$. Particles with excessive fracturing typically exhibited more visible damage to the OPyC and more extensive cracking in the Crystalbond. Therefore, the presence of faint radial fractures propagating into the Crystalbond layer was used as an initial selection criterion for identifying appropriately fractured particles.
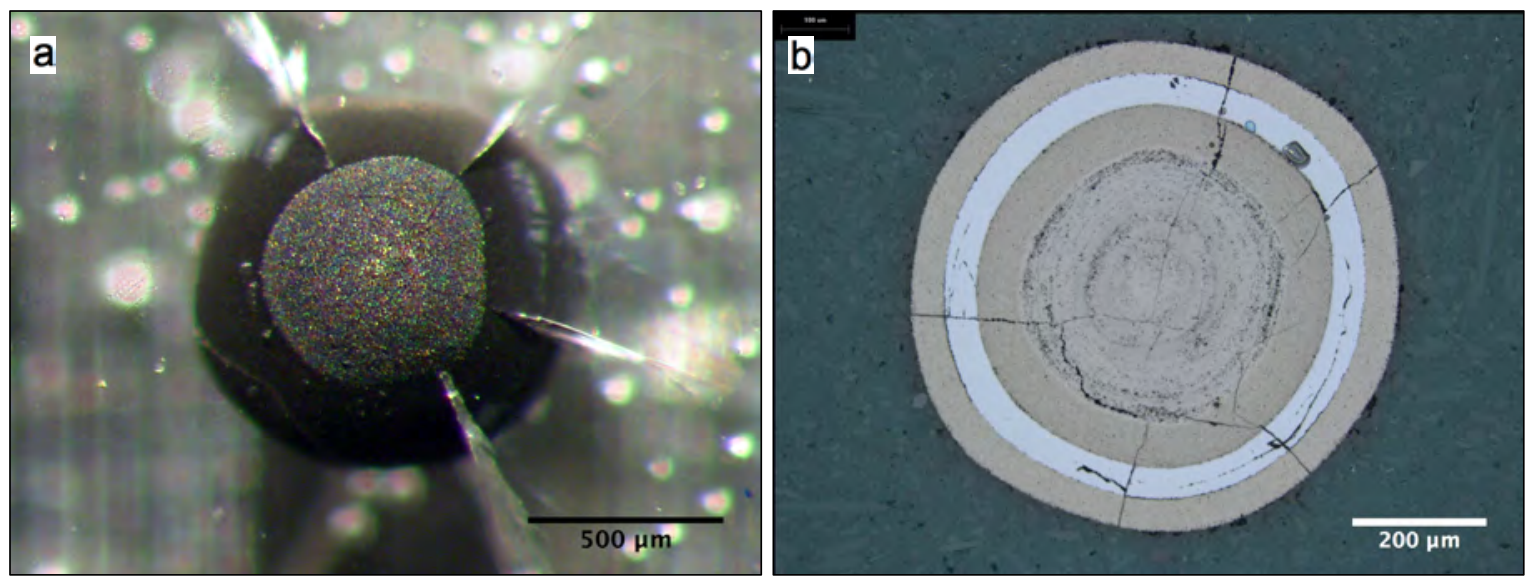

Figure 6. Optical images of impact-fractured particle after dropping a 75-g weight $1 \mathrm{~cm}$ : (a) particle embedded in Crystalbond with radial fractures extending into Crystalbond, and (b) polished cross section approximately normal to the impact site showing radial fracture traversing the TRISO layers.

The variable fracture response using the 75-g weight did not provide acceptable fracture behavior yields. To achieve a more repeatable fracture behavior, a lighter impact weight was utilized $(4.9 \mathrm{~g})$ and dropped from a greater height $(2.5-4 \mathrm{~cm})$. This procedural change was able to produce consistent faint radial fractures in the $\mathrm{OPyC}$ and Crystalbond. X-ray imaging was used as a non-destructive technique to confirm that each impact-fractured particle in the round robin test was cracked all the way through the TRISO layers. Figure 7 shows the correlation of TRISO layer cracks observed in x-ray analysis to the radial fractures observed after impact. Note, the tangential fracturing of the $\mathrm{SiC}$ layer seen in the polished cross section optical image in Figure $6 \mathrm{~b}$ was not observed in the lower weight impact fracture tests. 

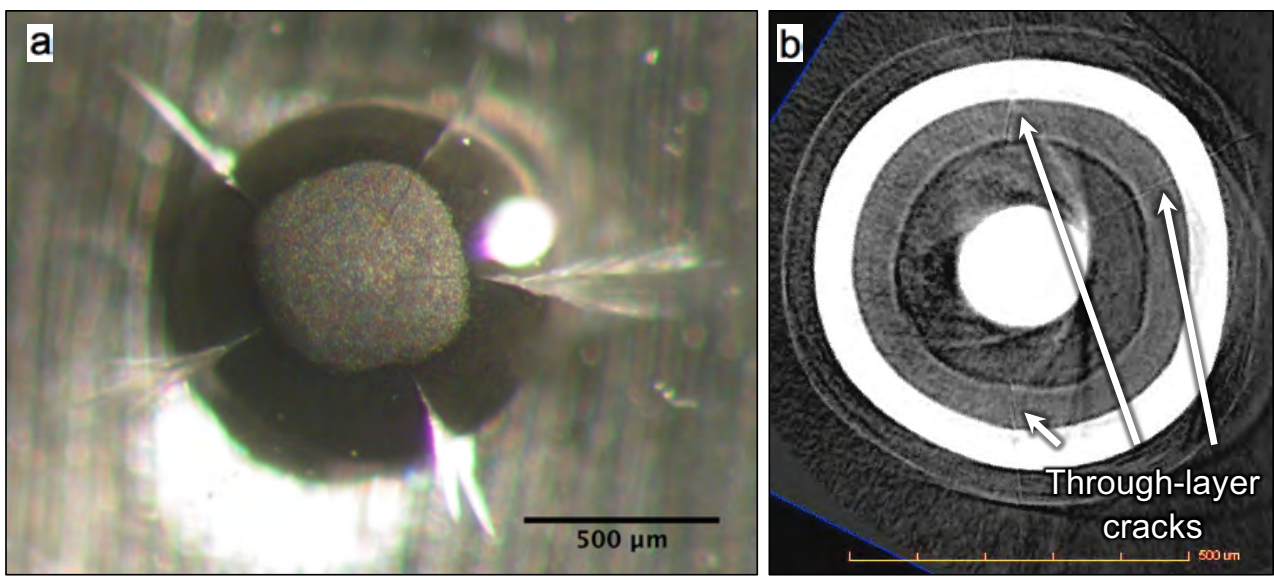

Figure 7. Example of results from a 4.90-g weight dropped $2.5 \mathrm{~cm}$ : (a) optical image showing faint radial fractures in OPyC and Crystalbond, and (b) $\mathrm{x}$-ray tomograph normal to impact direction showing cracks in TRISO layers.

Three-dimensional renderings of the $\mathrm{SiC}$ surface were investigated for select particles to gain further insight on the nature of the $\mathrm{SiC}$ fracture behavior. The three-dimensional renderings of the $\mathrm{SiC}$ surfaces demonstrate the nature of the fracture propagation; an example is presented in Figure 8, where faint fracturing can be observed to extend radially out from the impact site similar to the fractures propagating in the Crystalbond. The radial fractures ultimately terminate and do not extend around the entire circumference of the particle. This provides confidence that the particles will remain intact during handling.
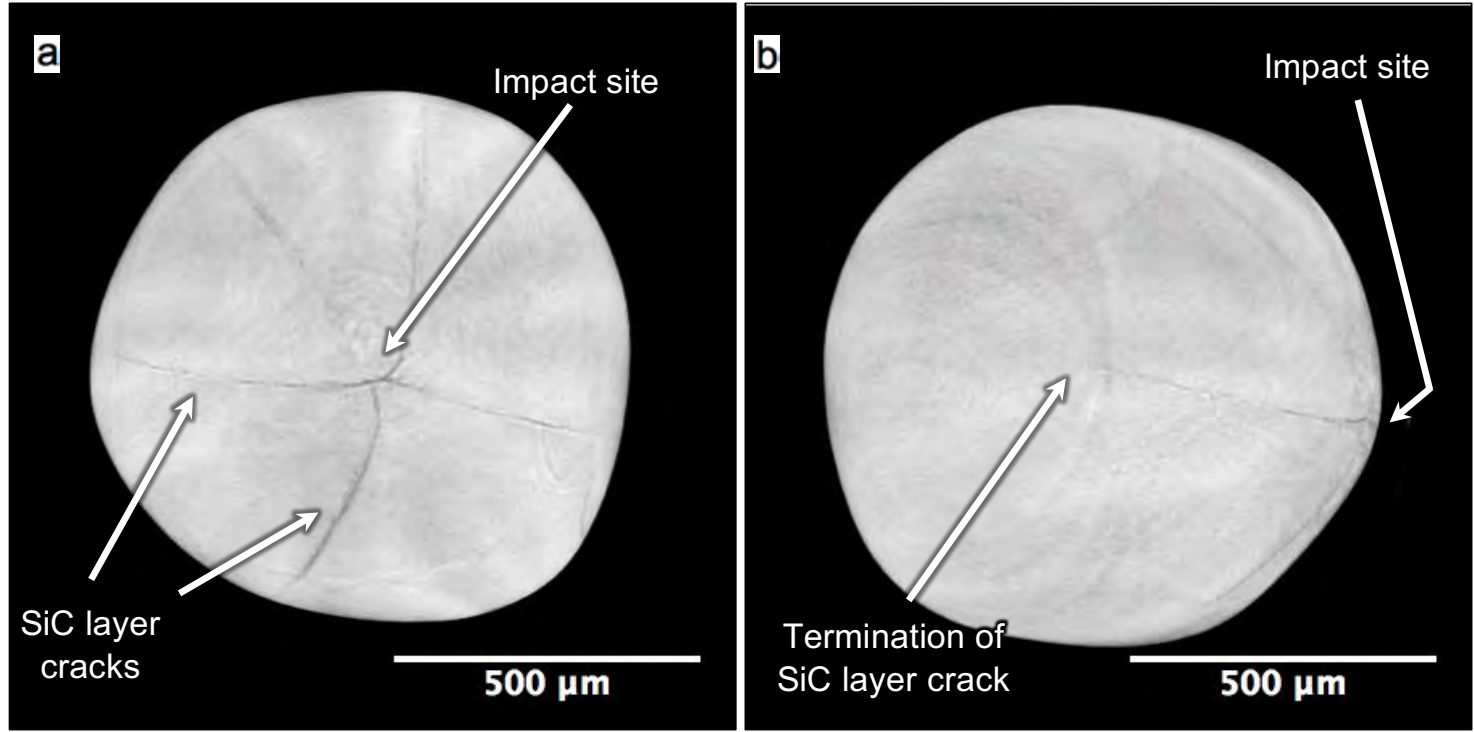

Figure 8. Three-dimensional $\mathrm{x}$-ray tomography visualization of a particle's $\mathrm{SiC}$ surface after impact fracturing with a 4.90-g weight dropped $2.5 \mathrm{~cm}$ : (a) view normal to the impact fracture showing radial fracture pattern, and (b) view rotated approximately 90 degrees to impact fracture site showing termination of one of the radial fractures.

Particles from DUN500S-10A were randomly selected for impact-fracture pre-burn leach simulated-defect fabrication. The prefix "GIF" and a sequential number (GIF-\#) were used to identify each impact-fractured particle. Fifty particles were fractured and particles with the appropriate visible fracture behavior in the OPyC and Crystalbond were analyzed with x-ray tomography to examine the nature of the fracture behavior. Appendix $C$ shows the optical images of all 50 particles subjected to impact fracturing. If a complete TRISO fracture was confirmed with $\mathrm{x}$-ray analysis, the particle was 
considered to be acceptable for inclusion in the round robin test. Figure 9 shows example optical and $\mathrm{x}$-ray images of a particle that exhibited acceptable impact fracture, where a fracture can be seen extending from the outside surface of the OPyC to the kernel, while the overall fracture damage is minimal. Appendix D shows x-ray tomographs of all particles confirmed for inclusion in the GIF LBL round robin experiment.
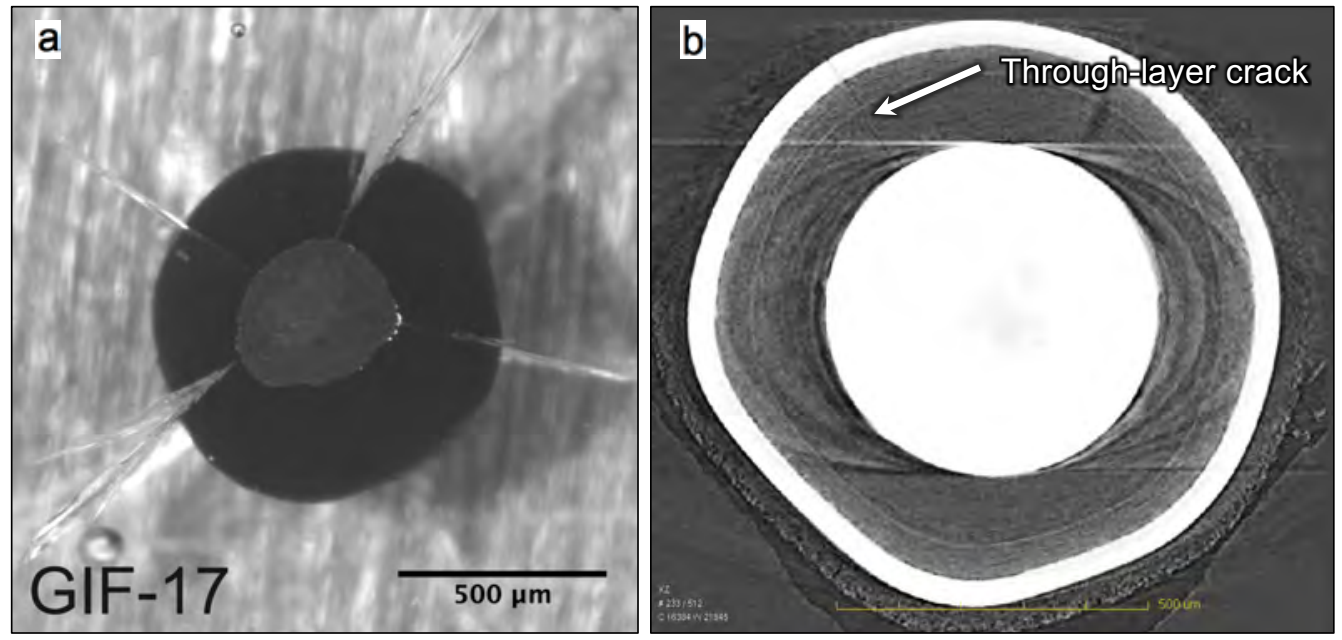

Figure 9. (a) Optical image of GIF-17 showing the OPyC and Crystalbond fracture after impact, and (b) x-ray tomograph showing the fracture propagating through the TRISO layers.

Particle GIF-48 was subjected to a pre-burn leach test to ensure that the kernel was exposed by the impact fracturing process and the simulated defect performed as expected. The leachate solutions were analyzed to measure the uranium content; and the uranium content in the first leachate was equivalent to $120 \pm 10 \%$ of the uranium in an average kernel, while $<0.1 \%$ was observed in the second leachate solution. This indicated the entire kernel content was leached in the first 24-hour leach step. X-ray radiography of the particle after the pre-burn leach indicated no kernel remained (Figure 10), corroborating the uranium analysis results and confirming the impact fractured particle acted properly as a simulated pre-burn leach (exposed kernel) defect.

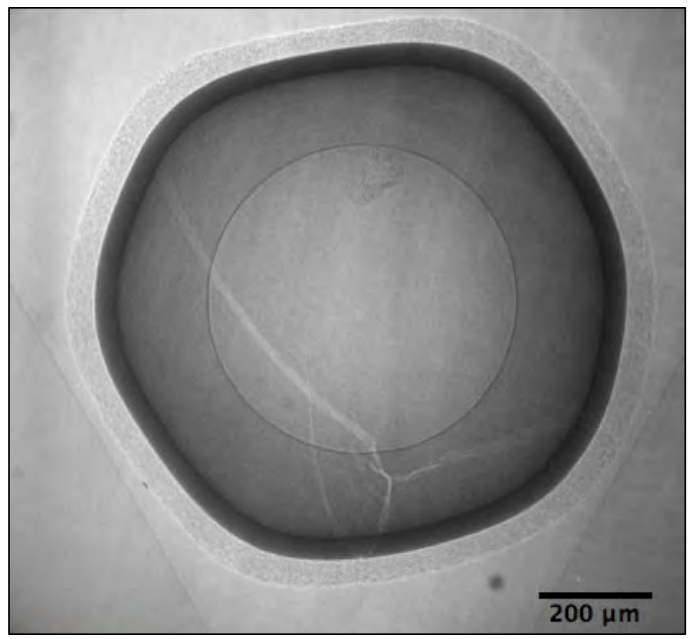

Figure 10. X-ray radiograph of GIF-48 showing complete absence of the $\mathrm{DUO}_{2}$ kernel after pre-burn leach.

Table 3 summarizes the observations made on the 50 particles involved in this study. Particles to be included in the round robin experiment are highlighted, and Appendix A identifies the sample assignment for each of these particles. The seven particles identified in Table 3 as "spare" are extra particles for use if assigned particles are lost or damaged. 
Table 3. Status of 50 particles from DUN500S-10A fabricated for inclusion in round robin experiment as simulated pre-burn leach defects using impact fracture method

\begin{tabular}{|c|c|c|c|c|}
\hline Particle ID & Imaging status & TRISO layer failure & $\begin{array}{c}\text { Number of } \\
\text { radial cracks }\end{array}$ & $\begin{array}{l}\text { Included in } \\
\text { round robin }\end{array}$ \\
\hline GIF-01 & Optical/x-ray & None confirmed & 1 & No \\
\hline GIF-02 & Optical/x-ray & Confirmed & 4 & Yes \\
\hline GIF-03 & Optical/x-ray & Confirmed & 3 & Yes \\
\hline GIF-04 & Optical/x-ray & Confirmed & 4 & Spare \\
\hline GIF-05 & Optical & - & 6 & - \\
\hline GIF-06 & Optical/x-ray & Confirmed & 4 & Yes \\
\hline GIF-07 & Optical/x-ray & Confirmed & 5 & Yes \\
\hline GIF-08 & Optical & - & 5 & - \\
\hline GIF-09 & Optical/x-ray & Confirmed & 5 & Yes \\
\hline GIF-10 & Optical & - & 5 & - \\
\hline GIF-11 & Optical & - & 5 & - \\
\hline GIF-12 & Optical/x-ray & Confirmed & 3 & Spare \\
\hline GIF-13 & Optical & - & 4 & - \\
\hline GIF-14 & Optical/x-ray & Confirmed & 5 & Yes \\
\hline GIF-15 & Optical/x-ray & Confirmed & 4 & Yes \\
\hline GIF-16 & Optical & - & 5 & - \\
\hline GIF-17 & Optical/x-ray & Confirmed & 4 & Yes \\
\hline GIF-18 & Optical & - & 6 & - \\
\hline GIF-19 & Optical/x-ray & Confirmed & 3 & Yes \\
\hline GIF-20 & Optical & - & 6 & - \\
\hline GIF-21 & Optical/x-ray & None confirmed & 4 & No \\
\hline GIF-22 & Optical & - & 5 & - \\
\hline GIF-23 & Optical & - & 4 & - \\
\hline GIF-24 & Optical & - & 6 & - \\
\hline GIF-25 & Optical & - & 6 & - \\
\hline GIF-26 & Optical & - & 5 & - \\
\hline GIF-27 & Optical/x-ray & Confirmed & 3 & Yes \\
\hline GIF-28 & Optical/x-ray & Confirmed & 3 & Yes \\
\hline GIF-29 & Optical/x-ray & Confirmed & 4 & Yes \\
\hline GIF-30 & Optical/x-ray & Confirmed & 3 & Yes \\
\hline GIF-31 & Optical & - & 3 & - \\
\hline GIF-32 & Optical & - & 3 & - \\
\hline GIF-33 & Optical/x-ray & Confirmed & 4 & Spare \\
\hline GIF-34 & Optical/x-ray & Confirmed & 3 & Spare \\
\hline GIF-35 & Optical/x-ray & Confirmed & 3 & Spare \\
\hline GIF-36 & Optical/x-ray & Confirmed & 4 & Spare \\
\hline GIF-37 & Optical/x-ray & Confirmed & 4 & Spare \\
\hline GIF-38 & Optical/x-ray & Confirmed & 3 & Yes \\
\hline GIF-39 & Optical/x-ray & Confirmed & 3 & Yes \\
\hline GIF-40 & Optical & - & 2 & - \\
\hline GIF-41 & Optical/x-ray & Confirmed & 4 & Yes \\
\hline GIF-42 & Optical/x-ray & Confirmed & 4 & Yes \\
\hline GIF-43 & Optical/x-ray & Confirmed & 3 & Yes \\
\hline GIF-44 & Optical/x-ray & Confirmed & 3 & Yes \\
\hline GIF-45 & Optical & - & 3 & - \\
\hline GIF-46 & Optical & - & 2 & - \\
\hline GIF-47 & Optical & - & 2 & - \\
\hline GIF-48 & Optical/x-ray & Confirmed & 3 & used for LBL \\
\hline GIF-49 & Optical/x-ray & Confirmed & 2 & Yes \\
\hline GIF-50 & Optical/x-ray & Confirmed & 4 & Yes \\
\hline
\end{tabular}




\section{FABRICATION OF SIMULATED POST-BURN LEACH DEFECTS}

The aim of simulated post-burn leach defect fabrication was to fabricate TRISO particles with a single penetration through the $\mathrm{SiC}$ layer and at least one intact pyrocarbon layer to protect the kernel from acid leaching prior to the burn stage of the LBL analysis. A dual-beam focused ion beam (FIB) milling system attached to a scanning electron microscope (SEM) was identified as an optimal instrument for production of controlled, micron-scale, local defects with a defined geometry; where a hole could be milled in the outer layers such that the $\mathrm{SiC}$ was penetrated while some portion of the IPyC remained intact.

The FIB utilized a 30-kV-gallium $\left(\mathrm{Ga}^{+}\right)$ion beam that was raster-scanned in predefined patterns to selectively sputter material from the target area. As part of initial development of a process to fabricate the simulated defect particles, multiple approaches were investigated to achieve fine-scale SiC defects in $\mathrm{ZrO}_{2}$-kernel surrogate TRISO particles. A circular, $10-\mu \mathrm{m}$-diameter raster pattern with a $30-\mathrm{kV}, 30-\mathrm{nA}$ $\mathrm{Ga}^{+}$ion beam produced the smallest hole through the $\mathrm{SiC}$ that displayed repeatable removal of the inner carbon layers during the burn stage. However, LBL analysis of DUN500S-10A particles with simulated post-burn leach defects produced inconsistent results that needed to be addressed before including these particles in the GIF LBL round robin experiment. The inconsistent results were presumed to be due to variable milling behavior related to redeposition of the milled $\mathrm{PyC}$ and $\mathrm{SiC}$ material, possible ion beam instabilities and specimen drift during milling, and the difficulty adjusting to the different ultimate simulated-defect depths required to optimally penetrate the different layer thicknesses in each particle. Polishing off a section of the OPyC layer to expose the $\mathrm{SiC}$ reduced the minimum depth for the simulated defects required for break-through into the IPyC layer, which mitigated issues related to the deeper holes; however, LBL inconsistencies remained. This implied milling variables and redeposition strongly influence the LBL behavior.
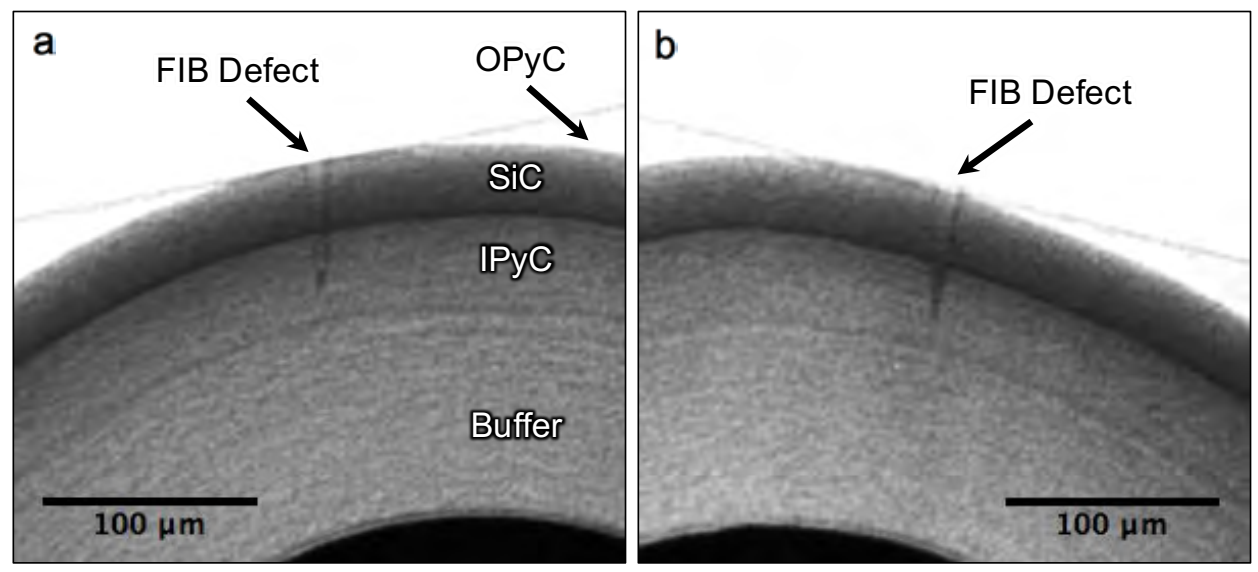

Figure 11. X-ray radiographs of DUN500S-10A particles with differing LBL behaviors showing a closeup of the FIB-fabricated through-layer defects: (a) particle with a simulated-defect penetrating $23-\mu \mathrm{m}$ deep into the IPyC layer, where the equivalent of $97 \%$ of an average kernel's total uranium content was dissolved in the post-burn leach; and (b) particle with a simulated-defect penetrating $28-\mu \mathrm{m}$ deep into the IPyC layer, where only $7 \%$ of an average kernel's total uranium content was dissolved in the post-burn leach.

Figure 11 shows x-ray radiographs of two particles with FIB-produced holes extending greater than $20-\mu \mathrm{m}$ into the IPyC layer. Both particles were subjected to LBL. Prior to subjecting the particles to LBL, a thin layer of epoxy was applied to the surface of the particles to help protect them from premature leaching during the pre-burn leaching phase. These particles clearly had through-layer SiC defects; however, two different results were observed. Post-burn leaching yielded approximately a single kernel's inventory of uranium from one particle but the other yielded only $\sim 7 \%$. The low uranium recovery observed in the second particle was not expected. During FIB-milling, an amorphous phase of $\mathrm{Ga}, \mathrm{Si}$, and $\mathrm{C}$ was redeposited at the bottom of the simulated-defect and on the simulated-defect walls. One hypothesis for the inconsistent behavior was that the redeposited material may have oxidized during the 
burn stage and clogged the hole that was milled through the SiC. The influence of redeposition in the particles presented in Figure 11 was not clear, as the hole could not be imaged along its length. This inconsistent behavior did not provide the confidence that the $10-\mu \mathrm{m}$-diameter simulated defects would behave as expected during the round robin testing, so a new approach was developed to more consistently produce simulated post-burn leach defects in the DUN500S-10A particles.

Two key changes in the simulated post-burn leach defect fabrication process were (1) to completely remove the OPyC layer from the DUN500S-10A particles by heating them in air at $750^{\circ} \mathrm{C}$, and (2) to program the FIB raster patterns to produce larger-diameter holes in the $\mathrm{SiC}$ layer. These changes ensured higher confidence in the through-layer nature of the simulated defects. The larger diameter holes and shallower ultimate hole depth allowed for direct confirmation with SEM imaging that the IPyC layer was exposed, while also minimizing the risk of penetrating too deeply into the IPyC. In addition, the large hole size mitigated the possibility of redeposition on the crater walls influencing the LBL process.

The indicators for successful fabrication of a FIB-produced simulated post-burn defect were determined by stepwise milling of a large-diameter hole. Multiple circular craters were produced with increasing milling times and the bottom of the craters were analyzed by SEM imaging. With increasing milling time, a transition in the visual appearance of the crater bottom was observed (Figure 12). For shorter milling times the crater bottoms were smooth and featureless, while a mottled surface appeared at the bottom of the craters milled for a longer time. This transition to a mottled surface indicated that the IPyC layer had been exposed, which was confirmed by additional analysis discussed below.
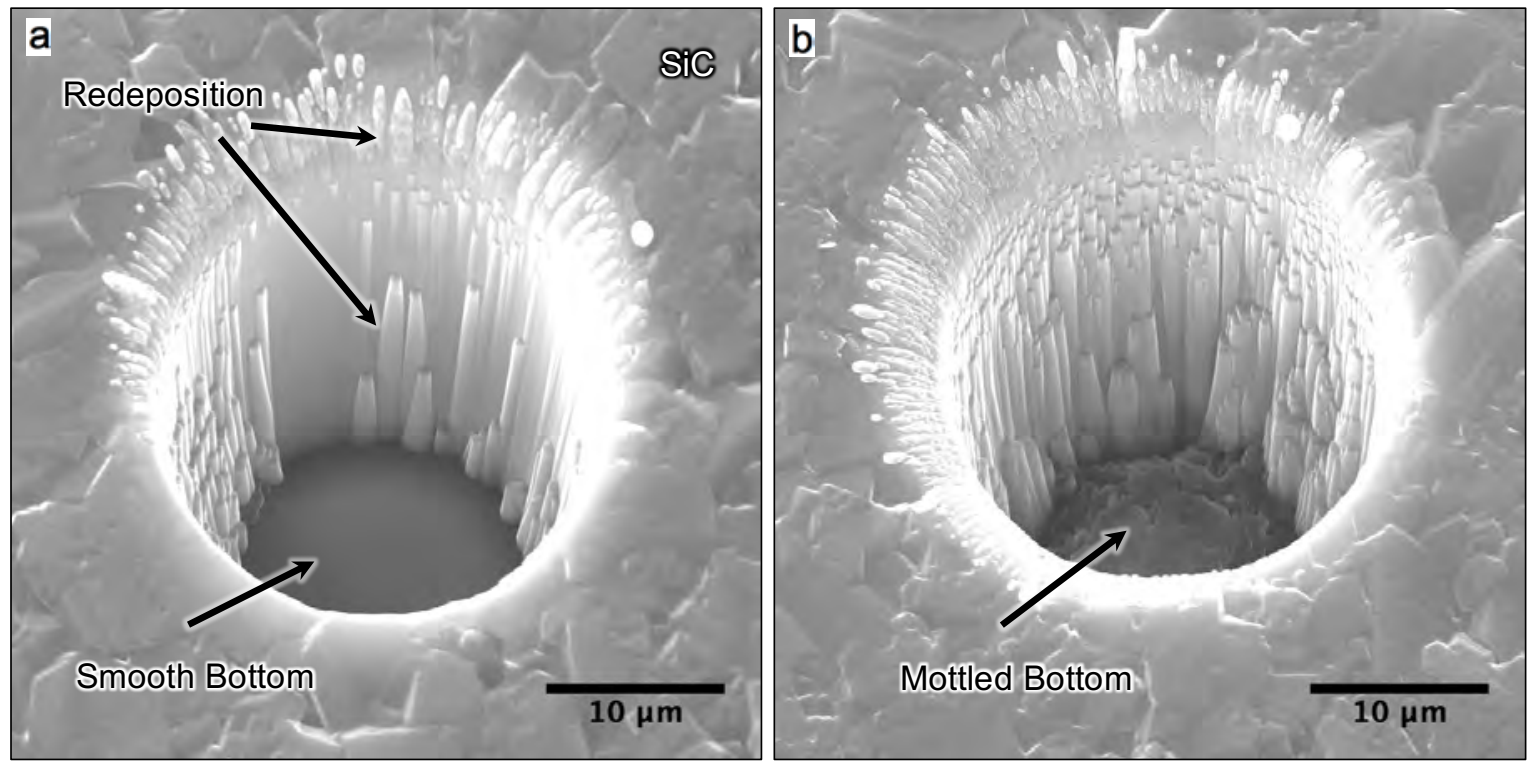

Figure 12. Secondary-electron SEM micrographs of craters produced with a 25 - $\mu$ m-diameter raster pattern showing the initial SiC surface, the sidewall, and the bottom of the craters. Both features were produced with a two-step milling process utilizing a 30-kV, 50-nA $\mathrm{Ga}^{+}$ion beam followed by a 30-kV, 15-nA $\mathrm{Ga}^{+}$ion beam: (a) $33 \mathrm{~min}$ at $50 \mathrm{nA}$ followed by $10 \mathrm{~min}$ at $15 \mathrm{nA}$, and (b) $38 \mathrm{~min}$ at $50 \mathrm{nA}$ followed by $10 \mathrm{~min}$ at $15 \mathrm{nA}$.

Imaging of the crater sidewalls was pursued to confirm the craters extended beyond the $\mathrm{IPyC} / \mathrm{SiC}$ interface. The sidewalls had significant redeposition buildup, such that direct imaging of the SiC/IPyC interface was not possible after primary milling. Therefore, on select particles, additional milling was performed to remove redeposited material from a localized area on the sidewall and allow better imaging. After cleaning the sidewalls, SEM imaging confirmed that the IPyC layer had been penetrated on samples with crater bottoms with a mottled appearance (Figure 13). However, sidewall cleaning resulted in redeposition on the crater bottom, so this method for confirming the ultimate depth of the simulateddefect was not used for the round robin specimens due to uncertainty associated with the influence of this secondary redeposition on the LBL behavior. 

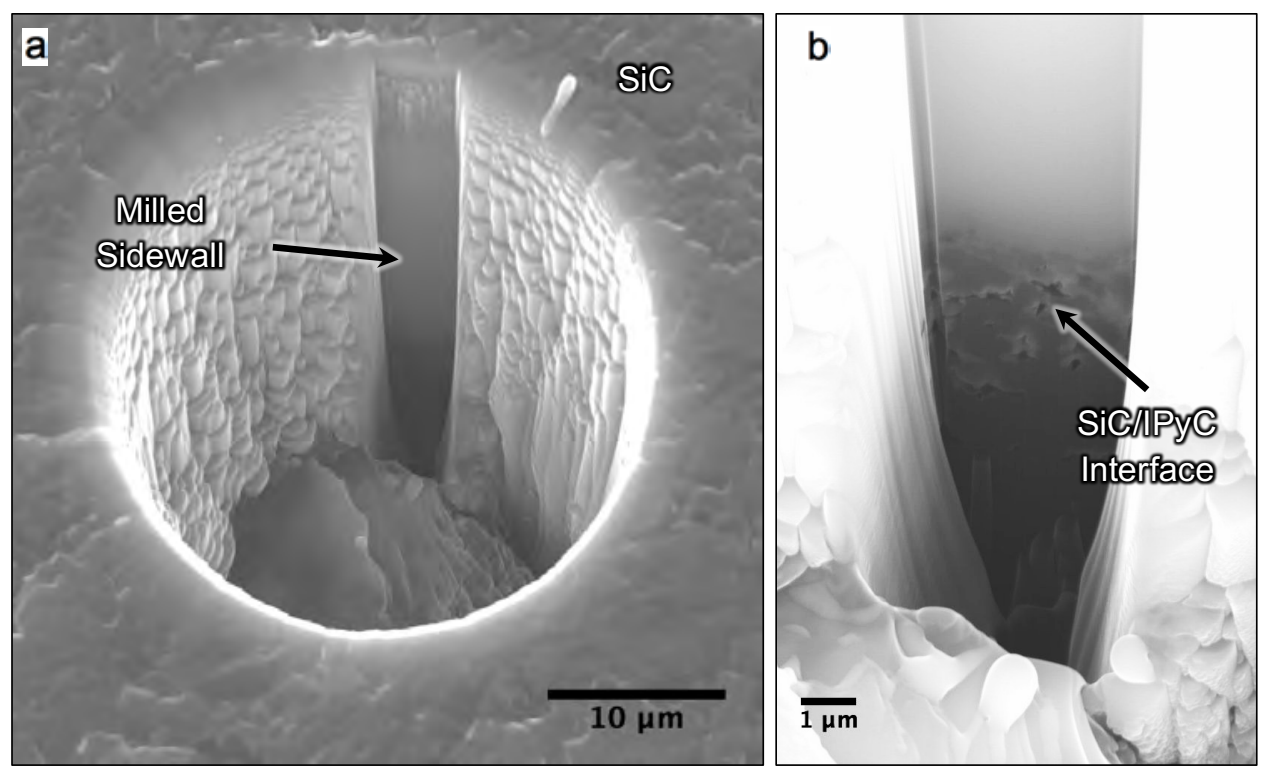

Figure 13. Secondary-electron SEM micrographs of a crater showing (a) the section of cleaned sidewall, and (b) a close up of the transition from SiC to IPyC confirming breakthrough into the IPyC layer.

X-ray radiographs were taken to determine the ultimate depth of each simulated defect. This analysis was complementary to the SEM imaging of the crater bottoms in verifying that the crater depths were optimized. SEM imaging confirmed that the $\mathrm{SiC}$ was penetrated and the IPyC was exposed, while the $\mathrm{x}$-ray radiographs confirmed that the milled holes did not penetrate into the IPyC layer to excessive depths. Confining the milling to the first few microns of the IPyC layer helps to ensure consistent behavior of the simulated post-burn leach defects and prevent premature leaching prior to the burn phase. Figure 14 shows two examples of the cross section images obtained by x-ray radiography. These radiographs indicate the crater bottoms terminate near the IPyC/SiC interface for both particles, while Figure 12 shows that only the particle shown on the right in both figures has the mottled-appearing crater bottom indicative of penetration into the IPyC. This highlights that confident determination of the through-layer nature of these simulated defects is not provided by the x-ray radiographs alone.
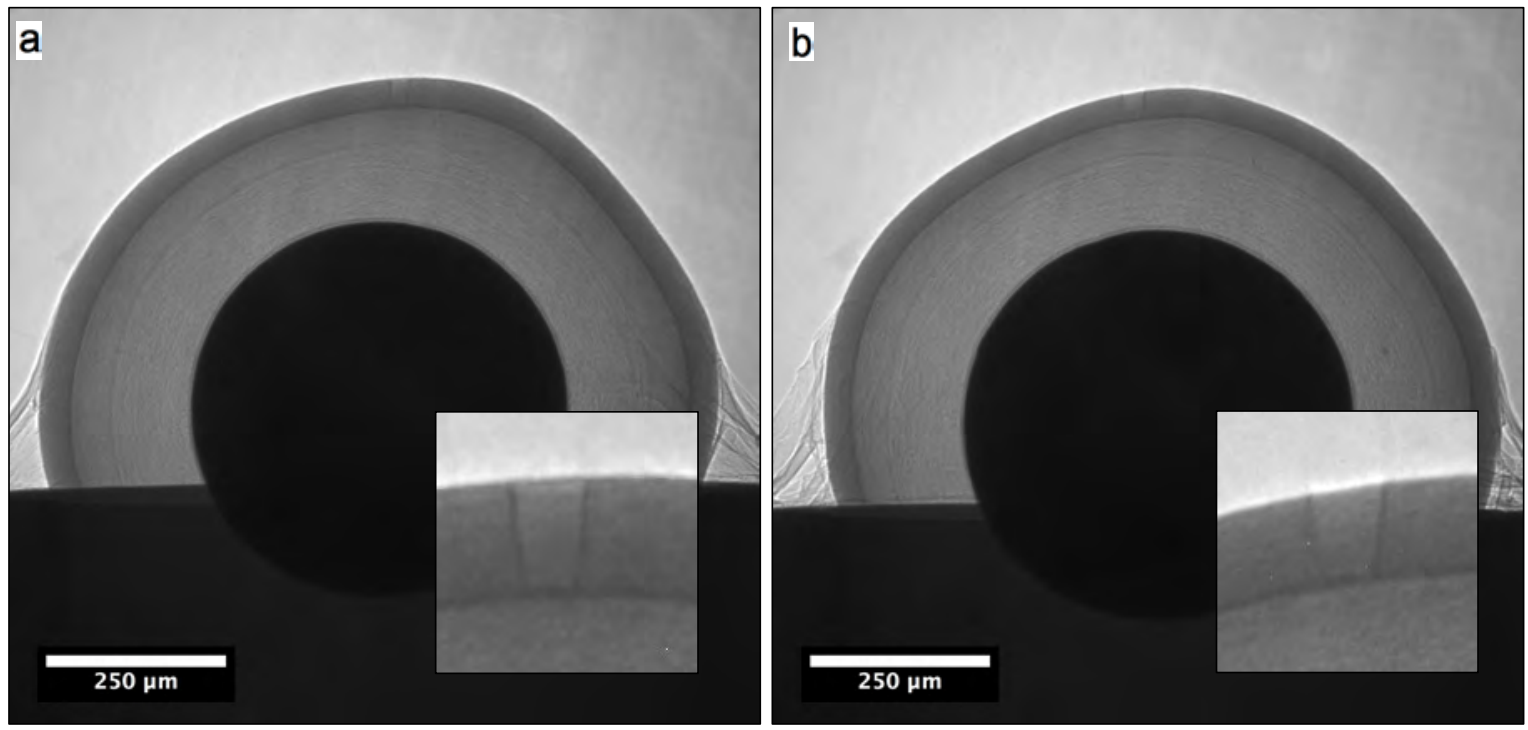

Figure 14. X-ray radiographs showing cross sections of the FIB-milled craters produced in the two particles shown in Figure 12: (a) particle with smooth crater bottom and (b) particle with mottled crater bottom (inset shows a close up of each feature). 
The SEM imaging provided confirmation that the IPyC layer had been reached through the milling process, however, the IPyC/buffer burn behavior needed to be confirmed to ensure the particles would behave as expected when using the mottled appearance at the bottom of the FIB-milled crater as an acceptance criterion. A total of fourteen particles with simulated post-burn leach defects milled to various depths were subjected to a $750^{\circ} \mathrm{C} 60$-hour burn to confirm the IPyC/buffer burn response. After the burn step, $\mathrm{x}$-ray radiographs were obtained of each particle to detemine whether or not the buffer and IPyC layers were burned out. All particles with the mottled-appearing crater bottom exhibited complete oxidation and removal of the buffer and IPyC layers, confirming that this SEM selection criteria was sufficient to ensure this process would occur as expected. Figure 15 shows the two particles that were imaged with SEM (Figure 12) and with x-ray (Figure 14) prior to the burn step. The particle on the left did not exhibit any sign of oxidation, confirming that the smooth-bottom crater indicates that the IPyC was not exposed. In contrast, the buffer and IPyC layers were burned out of the particle on the right and the kernel was expanded due to conversion to $\mathrm{U}_{3} \mathrm{O}_{8}$; this confirms that the particle with the mottledappearing crater bottom had an exposed IPyC layer.

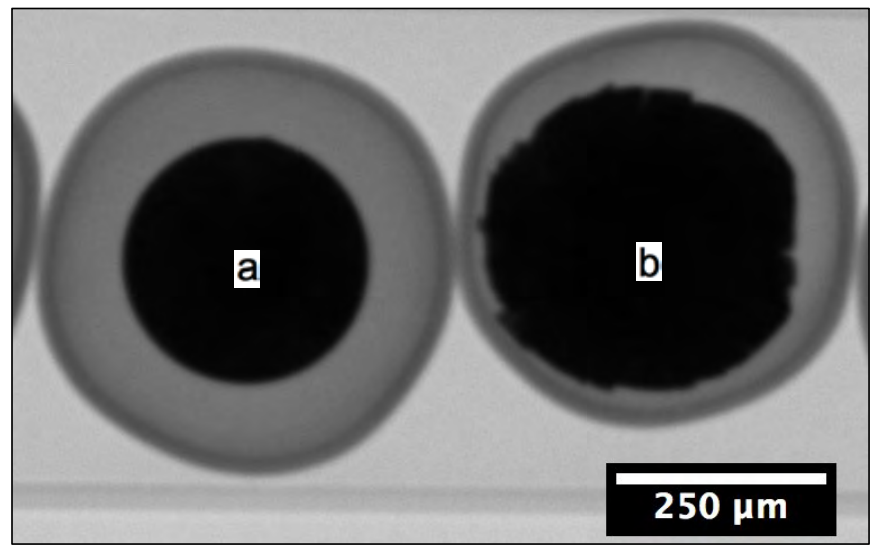

Figure 15. X-ray radiograph of the particles presented in Figure 12 after heating in air at $750^{\circ} \mathrm{C}$ for 60 hours: (a) particle with smooth crater bottom and (b) particle with mottled crater bottom.

After confirmation that the process of using a FIB to mill a large-diameter hole through the SiC provided reliable exposure of the IPyC, a test was performed to ensure that the process was controllable enough to prevent damage to the IPyC that might result in premature leaching. Ten particles with large-diameter simulated post-burn leach defects were fabricated, imaged by SEM and x-ray, and subjected to LBL analysis. The fabrication process utilized a $25-\mu \mathrm{m}$-diameter raster pattern with a $30-\mathrm{kV}, 30-\mathrm{nA} \mathrm{Ga}{ }^{+}$ion beam. Simulated-defects were introduced through the implementation of a stepwise process where an initial 25 - $\mu \mathrm{m}$-diameter crater was produced by a 73 -minute milling step followed by incremental milling for 2-4 minutes until the bottom of the crater showed the characteristic mottled surface that indicated the $\mathrm{SiC}$ had been penetrated and the IPyC was exposed.

Acceptance criteria were developed to ensure the milling process was reproducibly providing the required microstructure and to document that microstructure. The crater of each particle was first imaged with SEM to verify the bottom of the crater had the required mottled appearance, then an x-ray radiograph was taken to verify that the crater did not penetrate more than $10 \mu \mathrm{m}$ into the IPyC layer. An example of the acceptance analysis is shown in Figure 16. Because the crater bottom was sometimes difficult to identify in the x-ray radiographs, a small $\mathrm{Pt}$ dot was deposited at the bottom of each crater at the end of the milling process; this Pt deposit is also shown in Figure 16. The Pt was deposited using the FIB gas injection system, which can locally flood the target region with a Pt precursor gas. Platinum is deposited when the precursor gas interacts with the $\mathrm{Ga}^{+}$ion beam, and the deposition area can be controlled by rastering the beam. The Pt feature was deposited using a $30-\mathrm{kV}, 0.5-\mathrm{nA} \mathrm{Ga}{ }^{+}$beam and a 3.5 -minute, 3 - $\mu$ m-diameter raster pattern. The higher atomic mass of the Pt relative to the TRISO layers provided additional x-ray imaging contrast to confidently determine the ultimate depth of the crater. Additionally, the Pt was chemically-stable and sufficiently-small such that it would not interfere with the LBL process. 

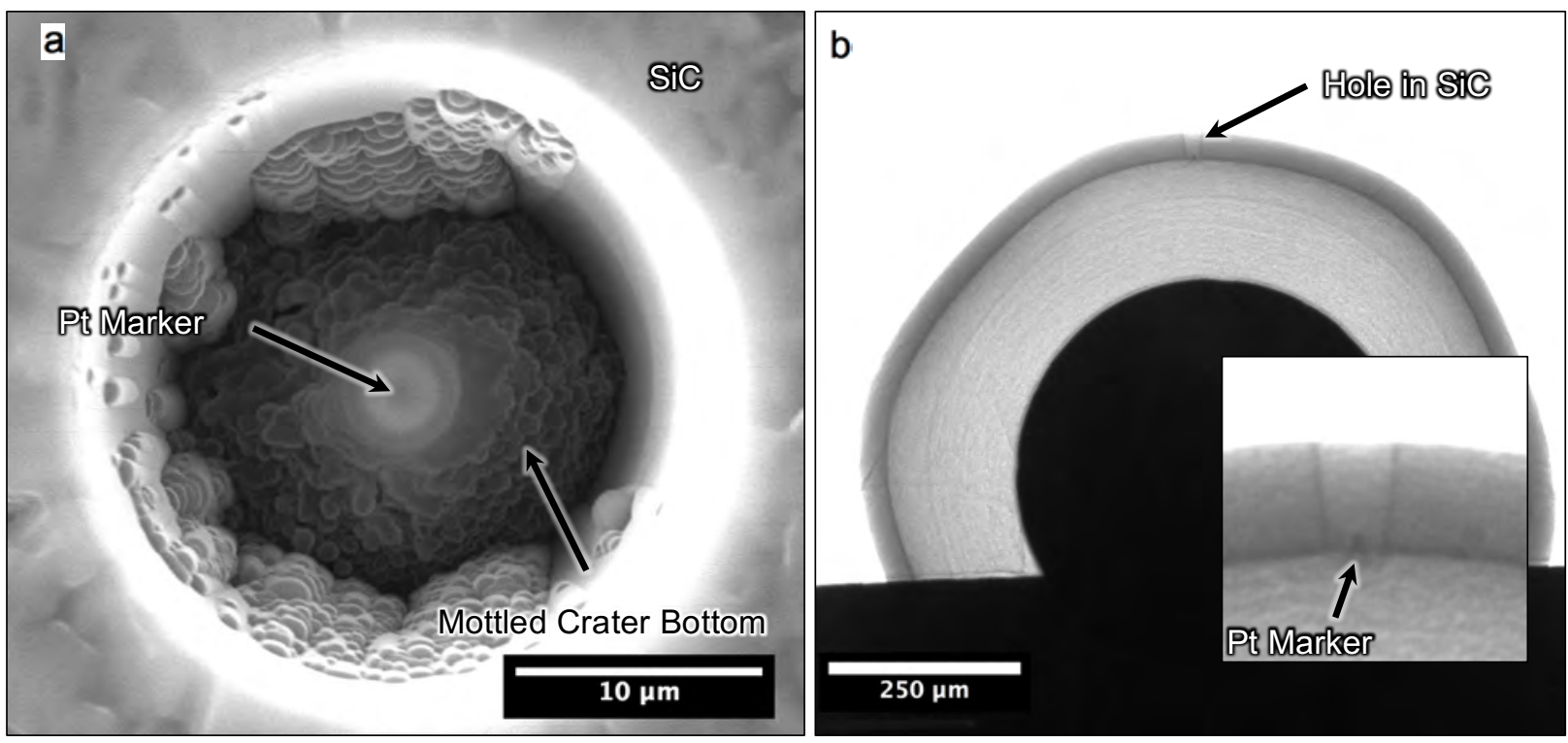

Figure 16. Two-part confirmation of acceptable microstructure for a simulated post-burn leach defect consisting of (a) secondary-electron SEM micrograph of the crater showing a mottled bottom with Pt marker, and (b) $\mathrm{x}$-ray radiograph of the crater cross section indicating crater termination near the IPyC/SiC interface (inset shows close-up of the crater with platinum marker at the bottom).

The ten particles fabricated to test the LBL behavior of the simulated post-burn leach defects met the required acceptance criteria and included the Pt marker. These particles were split into two groups of five and subjected to the standard ORNL LBL process (two 24-hour leaches in boiling nitric acid before and after a 60 -hour burn at $750^{\circ} \mathrm{C}$ in air). Table 4 shows that $4-5 \%$ of the total uranium inventory was detected in the pre-burn leach solutions and the total amount of uranium leached was within the measurement uncertainty of the uranium inventory expected in each five-particle sample. Essentially all the exposed uranium detected during pre-burn leaching was found in the second 24-hour leach, while the uranium measured during the post-burn leach was essentially all in the first 24-hour leach. This indicates that nitric acid was able to slowly permeate the IPyC layer and eventually extract a small fraction of uranium from the kernel during the pre-burn leach period, while the burn step resulted in complete exposure of the kernel material followed by effective dissolution of the uranium by the hot nitric acid. The small fraction of uranium leached through the IPyC layer prior to the burn will not adversely impact the primary goal of the round robin experiment, which is to count the number of particles with simulated LBL defects present in each round robin test sample (Table 1); and the essentially-complete post-burn leaching of five kernels in each sample demonstrated that the simulated post-burn leach defects will perform as needed.

Table 4. Results of LBL analysis on two test samples of five simulated post-burn leach defects

\begin{tabular}{cccc}
\hline $\begin{array}{c}\text { Test } \\
\text { sample }\end{array}$ & $\begin{array}{c}\text { Uranium detected in } \\
\text { pre-burn leach } \\
\text { (kernel fraction) }\end{array}$ & $\begin{array}{c}\text { Uranium detected in } \\
\text { post-burn leach } \\
\text { (kernel fraction) }\end{array}$ & $\begin{array}{c}\text { Total uranium detected } \\
\text { by LBL } \\
\text { (kernel fraction) }\end{array}$ \\
\hline 1 & $0.21 \pm 0.02$ & $4.58 \pm 0.47$ & $4.79 \pm 0.47$ \\
2 & $0.26 \pm 0.03$ & $4.62 \pm 0.47$ & $4.88 \pm 0.47$ \\
\hline
\end{tabular}

Reported kernel fractions are determined by dividing the mass of measured uranium in the leach solutions by the average mass of uranium in one kernel.

Figure 17 provides additional evidence of the slow permeability of nitric acid through the IPyC layer in the particles with simulated post-burn leach defects. In this x-ray tomograph, uranium leached from the kernel can be seen dispersed throughout the buffer and piled up against the inside surface of the IPyC. 


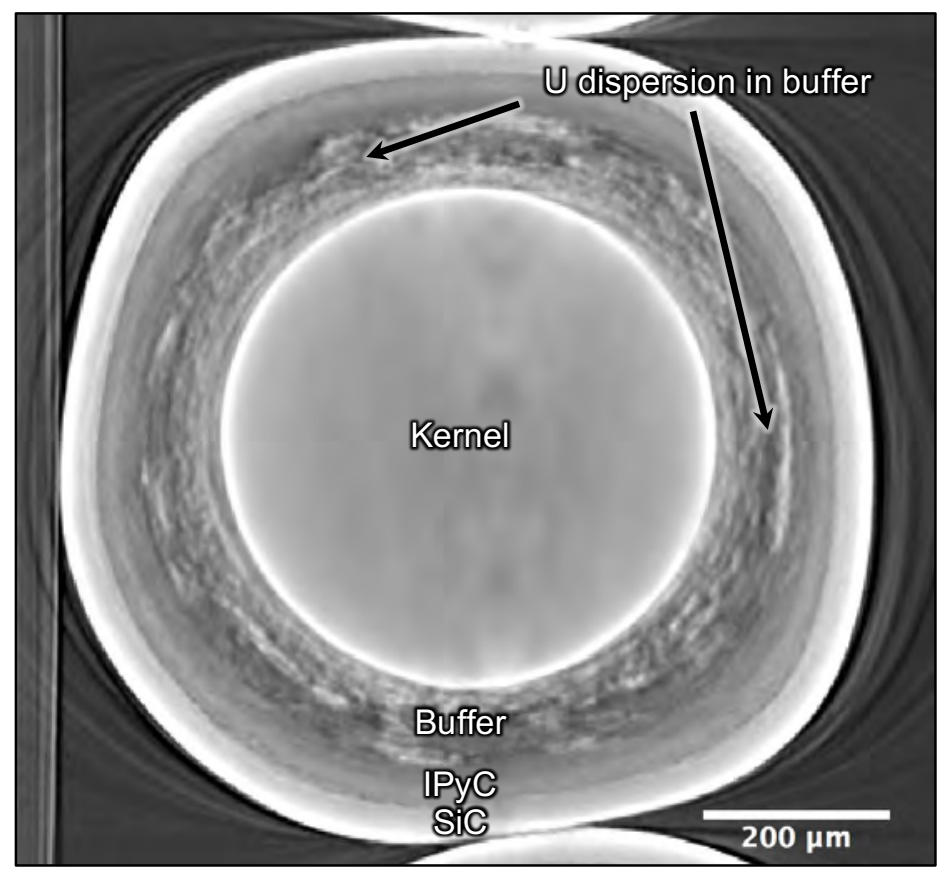

Figure 17. X-ray tomograph of a particle with a simulated post-burn leach defect after pre-burn leaching, where bright regions in the buffer layer indicates the presence of uranium that was extracted from the kernel by nitric acid permeating the presumably intact IPyC layer.

Figure 18 shows an x-ray tomograph of a particle with a simulated post-burn leach defect that was recovered after completion of post-burn leaching. X-ray tomography provided additional confirmation of the successful post-burn leach defect behavior. No buffer or IPyC layers were observed in the particles after post-burn leaching. These carbon layers were oxidized and removed during the burn stage (as shown in Figure 15b), and the oxidized kernel was leached out of the $\mathrm{SiC}$ shell. There was also no evidence of residual dispersed uranium.

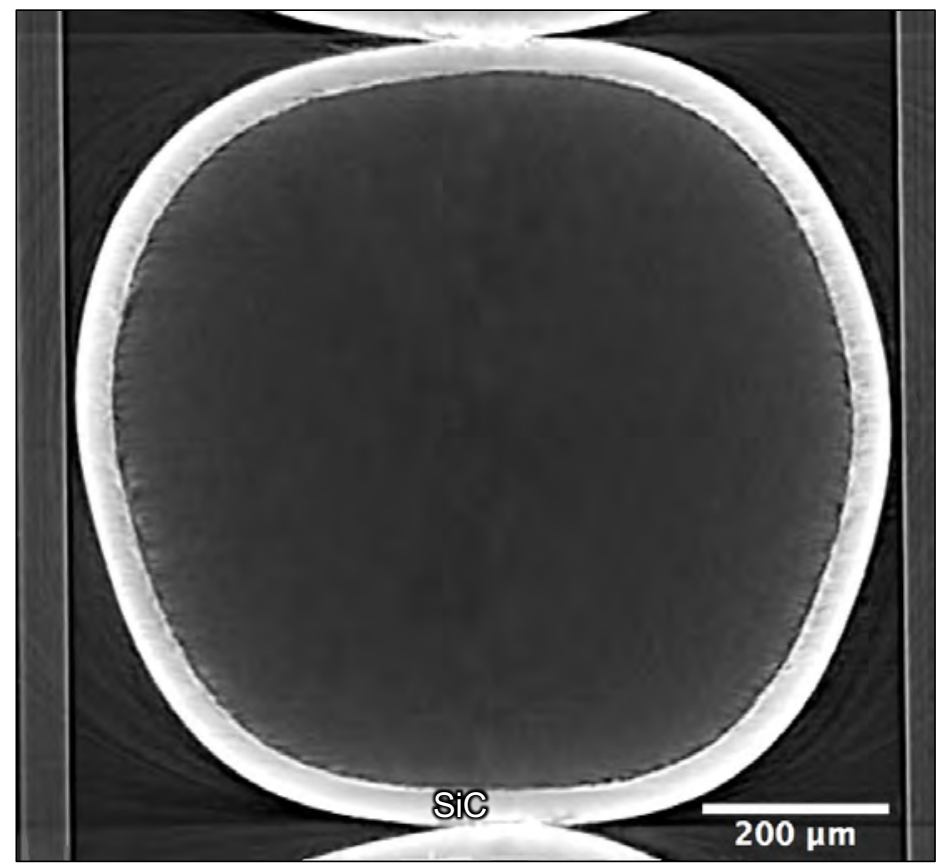

Figure 18. X-ray tomograph of a particle with a simulated post-burn leach defect after post-burn leaching, where buffer and IPyC were oxidized and removed during the burn stage and the kernel was completely leached during the post-burn leach. 
A total of 28 particles with simulated post-burn leach defects were fabricated with the same $25-\mu \mathrm{m}-$ diameter raster pattern and stepwise milling procedure used to make the ten particles tested with LBL. These 28 particles are identified as FIB-01 through FIB-28. Twenty-one particles will be included in the LBL round robin experiment and 7 are available as spares (as indicated in Table 5). Imaging with SEM and $\mathrm{x}$-ray was performed on all 28 particles to determine if they met the acceptance criteria discussed above; Appendix E shows the results of this imaging and Table 5 summarizes the status of the 28 particles. Appendix A identifies the sample assignment for each of these particles.

Table 5. Status of 28 particles from DUN500S-10A fabricated for inclusion in round robin experiment as simulated post-burn leach defects using FIB-milling method

\begin{tabular}{cccc}
\hline Particle ID & Imaging status & $\begin{array}{c}\text { Acceptable defect } \\
\text { microstructure }\end{array}$ & $\begin{array}{c}\text { Included in } \\
\text { round robin }\end{array}$ \\
\hline FIB-01 & SEM/x-ray & Confirmed & Spare \\
FIB-02 & SEM/x-ray & Confirmed & Yes \\
FIB-03 & SEM/x-ray & Confirmed & Yes \\
FIB-04 & SEM/x-ray & Confirmed & Spare \\
FIB-05 & SEM/x-ray & Confirmed & Yes \\
FIB-06 & SEM/x-ray & Confirmed & Yes \\
FIB-07 & SEM/x-ray & Confirmed & Yes \\
FIB-08 & SEM/x-ray & Confirmed & Yes \\
FIB-09 & SEM/x-ray & Confirmed & Yes \\
FIB-10 & SEM/x-ray & Confirmed & Yes \\
FIB-11 & SEM/x-ray & Confirmed & Yes \\
FIB-12 & SEM/x-ray & Confirmed & Spare \\
FIB-13 & SEM/x-ray & Confirmed & Yes \\
FIB-14 & SEM/x-ray & Confirmed & Yes \\
FIB-15 & SEM/x-ray & Confirmed & Yes \\
FIB-16 & SEM/x-ray & Confirmed & Yes \\
FIB-17 & SEM/x-ray & Confirmed & Yes \\
FIB-18 & SEM/x-ray & Confirmed & Spare \\
FIB-19 & SEM/x-ray & Confirmed & Yes \\
FIB-20 & SEM/x-ray & Confirmed & Yes \\
FIB-21 & SEM/x-ray & Confirmed & Yes \\
FIB-22 & SEM/x-ray & Confirmed & Spare \\
FIB-23 & SEM/x-ray & Confirmed & Yes \\
FIB-24 & SEM/x-ray & Confirmed & Spare \\
FIB-25 & SEM/x-ray & Confirmed & Yes \\
FIB-26 & SEM/x-ray & Confirmed & Yes \\
FIB-27 & SEM/x-ray & Confirmed & Yes \\
FIB-28 & SEM/x-ray & Confirmed & Spare \\
\hline
\end{tabular}




\section{SUMMARY}

The work scope of the GIF LBL benchmark round robin experiment has been defined for each participating institution. Effort at ORNL has included identifying $\mathrm{DUO}_{2}$ particles suitable for fabrication into simulated pre-burn and post-burn leach defects. Measurements were completed to determine the average uranium content per $\mathrm{DUO}_{2}$ particle and average weight percent ${ }^{235} \mathrm{U}$. This uranium data is necessary for the LBL analysis to determine the number of $\mathrm{DUO}_{2}$ kernels leached in each test sample. A data report form was developed by ORNL to assist in the collection of data and the analysis to determine the number of defective $\mathrm{DUO}_{2}$ particles present in each sample based on the total amount of leached uranium in each leachate.

Particles with simulated pre-burn and post-burn leach defects have been successfully fabricated. The vetting of the simulated defects included identification of the required defect behavior, development of fabrication methods to produce the defects, and validation of the simulated-defect performance. These particles will be shipped to INET and KAERI so they can proceed with round robin test sample analysis.

Pre-burn leach defects were simulated by designing a method to crack all the coating layers in a TRISO particle by transmitting the impact of a falling weight to one point on the surface of the particle through a small rod. This method successfully exposed the kernel without removing or excessively fracturing the TRISO coatings. Validation of all the simulated pre-burn leach defects to be included in the round robin experiment was accomplished by x-ray imaging each particle to confirm that all coatings had throughlayer cracks. One particle was subjected to destructive LBL analysis to verify that the simulated defect exhibited the proper pre-burn leach behavior, and this test showed full leaching of the kernel during the first 24-hour leach.

Post-burn leach defects were simulated by milling a hole through the $\mathrm{SiC}$ layer of each particle without excessively penetrating or damaging the overall integrity of the IPyC layer. To assist in the control of this process, the $\mathrm{OPyC}$ layer was first removed by burning it off in air at $750^{\circ} \mathrm{C}$, then a relatively large hole was milled with a FIB through the $\mathrm{SiC}$ using a $25-\mu \mathrm{m}$-diameter raster pattern. This large hole allowed for sufficient control of the milling process, reduction in the interference from redeposited material, and direct imaging of the milled crater during fabrication. The size of the hole used to simulate the behavior of a post-burn leach defect is not ideal from the standpoint of accurately replicating the smaller-scale SiC defects that have been observed in TRISO particles or challenging the ultimate ability of air and liquid in penetrating very small defects. However, the experimental impact of simulated defects not performing as intended was an important consideration, and larger diameter holes were determined to be the best solution given the limitations of the available equipment and resources. Validation of the simulated post-burn leach defects was accomplished by SEM and x-ray imaging of the FIB-produced crater in all particles to be used in the experiment. The combination of these two imaging techniques confirmed that each particle with a simulated burn-leach defect had a fully exposed IPyC layer without penetration beyond the outer $10 \mu \mathrm{m}$ of IPyC. The LBL performance of the particles with simulated post-burn leach defects was verified by subjecting ten particles to destructive LBL analysis, with the results indicating the FIB-produced specimens behaved as required. 


\section{REFERENCES}

Baldwin, C.A., J.D. Hunn, R.N. Morris, F.C. Montgomery, C.M. Silva, and P.A. Demkowicz. 2012. "First Elevated Temperature Performance Testing of Coated Particle Fuel Compacts from the AGR-1 Irradiation Experiment." Paper HTR2012-3-027 in Proceedings of the 6th International Topical Meeting on High Temperature Reactor Technology - HTR 2012, Tokyo, Japan, October 28November 1, 2012. Also published in Nuclear Engineering and Design 271: 131-141.

Hunn, J.D. 2013. "Leach-Burn-Leach Analysis at ORNL for US VHTR Fuel Development and Qualification." presented at the GIF-VHTR-Fuel and Fuel Cycle Project Management Board Meeting, Cadarache, France, December 12, 2013.

Hunn, J.D., R.N. Morris, C.A. Baldwin, F.C. Montgomery, C.M. Silva, and T.J. Gerczak. 2013. AGR-1 Irradiated Compact 4-4-2 PIE Report: Evaluation of As-Irradiated Fuel Performance with Leach Burn Leach, IMGA, Materialography, and X-ray Tomography. ORNL/TM-2013/236, Revision 0. Oak Ridge, Tennessee: Oak Ridge National Laboratory.

Lowden, R.A., and J.C. McLaughlin. 2004. Fluidized Bed Coating of 500 um Depleted Uranium Oxide Kernels. ORNL/CF-04/13, Revision 0. Oak Ridge, Tennessee: Oak Ridge National Laboratory.

Petti, D.A., J.T. Maki, J.D. Hunn, P.J. Pappano, C.M. Barnes, J.J. Saurwein, S.G. Nagley, J.M. Kendall, and R.R. Hobbins. 2010. "The DOE Advanced Gas Reactor Fuel Development and Qualification Program.” JOM 62(9): 62-66. 


\section{Appendix A. ROUND ROBIN TEST SAMPLE BLENDING}

The following tables identify the specific particles with simulated LBL defects in each specimen vial (Table A1) and which round robin test sample each vial is to be added to (Table A2). Particles labeled "GIF" have simulated pre-burn leach defects and particles labeled "FIB" have simulated post-burn leach defects.

Table A1. Contents of each vial containing simulated $\mathrm{LBL}$ defects for seeding in riffled $\mathrm{ZrO}_{2}$ sublots.

\begin{tabular}{cccc}
\hline Sample vial ID & $\begin{array}{c}\text { Number of pre-burn } \\
\text { leach defects }\end{array}$ & $\begin{array}{c}\text { Number of post-burn } \\
\text { leach defects }\end{array}$ & $\begin{array}{c}\text { Simulated LBL-defect } \\
\text { particle IDs }\end{array}$ \\
\hline Vial 1 & 1 & 0 & GIF-02 \\
Vial 2 & 2 & 0 & GIF-03, GIF-06 \\
Vial 3 & 4 & 0 & GIF-07, GIF-09, GIF-14, GIF-15 \\
Vial 4 & 1 & 0 & GIF-17 \\
Vial 5 & 2 & 0 & GIF-19, GIF-27 \\
Vial 6 & 4 & 0 & GIF-28, GIF-29. GIF-30, GIF-38 \\
Vial 7 & 1 & 0 & GIF-39 \\
Vial 8 & 2 & 0 & GIF-41, GIF-42 \\
Vial 9 & 4 & 0 & GIF-43, GIF-44, GIF-49, GIF-50 \\
Vial 10 & 0 & 1 & FIB-02 \\
Vial 11 & 0 & 2 & FIB-03, FIB-05 \\
Vial 12 & 0 & 1 & FIB-06, FIB-07, FIB-08, FIB-09 \\
Vial 13 & 0 & 2 & FIB-11, FIB-13 \\
Vial 14 & 0 & 4 & FIB-14, FIB-15, FIB-16, FIB-17 \\
Vial 15 & 0 & 1 & FIB-19 \\
Vial 16 16 & 2 & FIB-20, FIB-21 \\
Vial 17 & 0 & 4 & FIB-23, FIB-25, FIB-26, FIB-27 \\
Vial 18 & 0 & & \\
\hline
\end{tabular}

Table A2. Plan for seeding $\mathrm{ZrO}_{2}$-TRISO sublots with simulated LBL defects.

\begin{tabular}{|c|c|c|c|}
\hline $\begin{array}{l}\text { Ship seeded } \\
\text { sample to: }\end{array}$ & Test sample ID & Vial to be added & $\begin{array}{c}\text { Re-label for blind study } \\
\qquad(?=\mathrm{A}-\mathrm{G})^{*}\end{array}$ \\
\hline \multirow{7}{*}{ INET } & INET-1 & No defect particles added & INET-? \\
\hline & INET-2 & Vial 1 & INET-? \\
\hline & INET-3 & Vial 2 & INET-? \\
\hline & INET-4 & Vial 3 & INET-? \\
\hline & INET-5 & Vial 10 & INET-? \\
\hline & INET-6 & Vial 11 & INET-? \\
\hline & INET-7 & Vial 12 & INET-? \\
\hline \multirow{7}{*}{ KAERI } & KAERI-1 & No defect particles added & KAERI-? \\
\hline & KAERI-2 & Vial 4 & KAERI-? \\
\hline & KAERI-3 & Vial 5 & KAERI-? \\
\hline & KAERI-4 & Vial 6 & KAERI-? \\
\hline & KAERI-5 & Vial 13 & KAERI-? \\
\hline & KAERI-6 & Vial 14 & KAERI-? \\
\hline & KAERI-7 & Vial 15 & KAERI-? \\
\hline \multirow{7}{*}{ ORNL } & ORNL-1 & No defect particles added & ORNL-? \\
\hline & ORNL-2 & Vial 7 & ORNL-? \\
\hline & ORNL-3 & Vial 8 & ORNL-? \\
\hline & ORNL-4 & Vial 9 & ORNL-? \\
\hline & ORNL-5 & Vial 16 & ORNL-? \\
\hline & ORNL-6 & Vial 17 & ORNL-? \\
\hline & ORNL-7 & Vial 18 & ORNL-? \\
\hline
\end{tabular}

* Randomly re-label each sample set from 1-7 to A-G so that only preparer knows the number and type of simulated-defect in each sample. 


\section{Appendix B. EXAMPLE OF EXCEL DATA REPORT FORM FOR ROUND ROBIN EXPERIMENT}

The following table is an example of a completed data report form in the Excel workbook designed to compile data from the round robin experiment. Data is input into the green cells. Blue cell are results of Excel calculations using data in the green cells.

\begin{tabular}{|c|c|c|c|c|c|c|c|c|c|}
\hline \multicolumn{2}{|c|}{ Data from Preliminary Mcasurements } & Units & \multicolumn{3}{|c|}{ Notes } & & & & \\
\hline $\begin{array}{l}\text { Avverage Total U per DU02-TRISO } \\
\text { Average Fraction U-235 in DU02-TRISO }\end{array}$ & $\begin{array}{c}7.003 \mathrm{E}-04+1-1.7 \mathrm{E}-06 \\
0.00217+0.0003\end{array}$ & $\begin{array}{l}\text { grams U/particle } \\
\end{array}$ & $\begin{array}{l}\text { Value provided by ORNL } \\
\text { Vife rovided b ORN }\end{array}$ & & & & & & \\
\hline & & & & & & & & & \\
\hline & EXAMPLE-A & EXAMPLE-B & EXAMPLE-C & EXAMPLE-D & EXAMPLE-E & EXAMPLE-F & EXAMPLE-G & Units & Noles \\
\hline \begin{tabular}{|l} 
Sample Weight \\
\end{tabular} & $78.500+1-0.003$ & $78.000+/-0.005$ & $78.200+1-0.0001$ & $\begin{array}{c}78.600+1 /-0.002 \\
\text { Pre-bumm Leach Da }\end{array}$ & $78.400+1-0.004$ & $78.500+/-0.003$ & $78.600+/-0.001$ & grams & articipating \\
\hline Total U Leached & $7.003 \mathrm{E}-04+\%-6.0 \mathrm{E}-05$ & $2.040 \mathrm{E}-03+1-6.5 \mathrm{E}-05$ & $2.840 \mathrm{E}-06+1-1.0 \mathrm{E}-106$ & $2.940 \mathrm{E}-06+1-1.0 \mathrm{E}-06$ & $6.230 \mathrm{E}-04+1-7.5 \mathrm{E}-05$ & $2.800 \mathrm{E}-033+/-8.5 \mathrm{E}-0.5$ & $2.940 \mathrm{E}-06+1-1.2 \mathrm{E}-06$ & grams & Measured by participating organization \\
\hline Effective number of exposed DU kernels & $1.00+1-0.09$ & $2.91+1-0.09$ & $0.00+i-0.00$ & $0.00+1-0.00$ & $0.89+1-0.11$ & $4.00+1-0.12$ & $0.00+/-0.00$ & kernels & Calculated by spreadsheet \\
\hline \begin{tabular}{|l|l|} 
Fe Leached \\
\end{tabular} & $1.89 \mathrm{E}-06+1-1.9 \mathrm{EE}-07$ & $1.51 \mathrm{E}-07+1-2.1 \mathrm{E}-07$ & $1.51 E-07+1-1.5 E-08$ & $1.51 E-07+1-1.5 E-08$ & $1.51 \mathrm{E}-07+1-1.5 \mathrm{E}-08$ & 1.51E-07+l-1.5E-08 & $1.51 \mathrm{E}-07+1-1.5 \mathrm{E}-08$ & grams & Measurued by participating organization \\
\hline Cr Leached & $1.41 \mathrm{E}-06+\%-1.4 \mathrm{E}-07$ & $1.69 \mathrm{E}-06+1-2.8 \mathrm{E}-07$ & $1.69 \mathrm{E}-06+1-1.7 \mathrm{E}-07$ & $1.69 \mathrm{E}-06+1-1.7 \mathrm{E}-07$ & $1.69 \mathrm{E}-06+\%-1.7 \mathrm{E}-07$ & $1.69 \mathrm{E}-06+1-1.7 \mathrm{E}-07$ & $1.69 \mathrm{E}-06+/-1.7 \mathrm{E}-07$ & grams & Measured by participating organization \\
\hline \begin{tabular}{|l|} 
Mn Leached \\
Colcached
\end{tabular} & $\frac{2.00 E-07+1-2.0 \mathrm{E}-08}{5.60 \mathrm{E}-07+1-5 \mathrm{E}-08}$ & 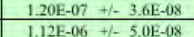 & $\frac{1.20 E-17+1-1.2 E-08}{1.122-06+1.1 E-07}$ & $\frac{1.20 E-07+1-1.2 E-08}{1.12 E-06}$ & $\frac{1.20 \mathrm{E}-07+1-1.2 \mathrm{E}-08}{1.122-06+1.1 \mathrm{E}-07}$ & \begin{tabular}{|l|l}
$1.20 \mathrm{E}-07+-1.1 .2 \mathrm{E}-08$ \\
$1.12 \mathrm{E}-06$ \\
\end{tabular} & 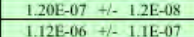 & $\begin{array}{c}\text { grams } \\
\text { grams }\end{array}$ & \begin{tabular}{|l} 
Mecasured by participating organiziztion \\
Measured by participanting organizition
\end{tabular} \\
\hline Ni Leached & $1.00 \mathrm{E}-06 \mathrm{06}+1-1.0 \mathrm{E}-107$ & 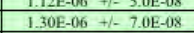 & $1.30 \mathrm{E}-06+1-1.1 .3 \mathrm{E}-017$ & 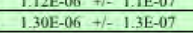 & 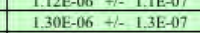 & 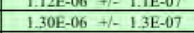 & 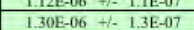 & $\begin{array}{l}\text { grams } \\
\text { grams } \\
\end{array}$ & 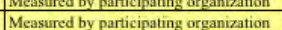 \\
\hline Al Leached & $1.40 \mathrm{E}-05+1-1.4 \mathrm{E}-106$ & $1.96 \mathrm{E}-05+1-2.0 \mathrm{E}-06$ & $1.96 \mathrm{E}-05+1-2.0 \mathrm{E}-106$ & $1.96 \mathrm{E}-05+1-2.0 \mathrm{E}-06$ & $1.96 \mathrm{E}-05+1-2.0 \mathrm{E}-106$ & $1.96 \mathrm{E}-05+1-2.0 \mathrm{E}-06$ & $1.96 \mathrm{E}-015+/-2.0 \mathrm{E}-06$ & grams & Measured by participating organization \\
\hline Ti Leached & $4.96 \mathrm{E}-06+5-5.0 \mathrm{E}-07$ & $3.97 \mathrm{E}-06+1-5.0 \mathrm{E}-07$ & $3.97 \mathrm{E}-06+1-4.0 \mathrm{E}-07$ & $3.97 \mathrm{E}-06 \mathrm{6}+1-4.0 \mathrm{E}-07$ & $3.97 \mathrm{E}-06+1-4.0 \mathrm{E}-07$ & $3.97 \mathrm{E}-06+1-4.0 \mathrm{EE}-07$ & $3.97 \mathrm{E}-06+1-4.0 \mathrm{E}-07$ & grams & Measured by participating organization \\
\hline V Leached & $2.25 E-05+1-2.3 E-16$ & $2.70 \mathrm{E}-05+1-2.5 \mathrm{E}-06$ & $2.70 E-05+1-2.7 E-06$ & $\frac{2.70 E-05+1-2.7 E-06}{\text { Post-berm Leach Das }}$ & $2.70 E-05+1-2.7 \mathrm{E}-166$ & $2.70 \mathrm{E}-05+1-2.7 \mathrm{E}-06$ & $2.70 \mathrm{E}-05+1-2.7 \mathrm{E}-16$ & & Measure \\
\hline \begin{tabular}{|l} 
Total U Leached \\
\end{tabular} & $2.840 \mathrm{E}-06+/-3.0 \mathrm{E}-07$ & $2.940 \mathrm{E}-166+/-1.0 \mathrm{E}-07$ & $1.400 \mathrm{E}-03+1-4.9 \mathrm{E}-05$ & $3.940 \mathrm{E}-166+1-2.1 \mathrm{E}-07$ & $2.900 \mathrm{E}-03+1-3.5 \mathrm{E}-04$ & $9.840 \mathrm{E}-016+1-3.0 \mathrm{E}-07$ & $2.650 \mathrm{E}-03+/-6.5 \mathrm{E}-05$ & grams & Measured by participating organization \\
\hline Effective number of exposed DU kernels & $0.00+i-0.00$ & $0.00+1-0.00$ & $2.00+1-0.07$ & $0.01+1-0.00$ & $4.14+\%-0.50$ & $0.01+1-0.00$ & $3.78+1-0.09$ & kernels & Calculated by spreadsheet \\
\hline Fe Leached & $1.89 \mathrm{E}-06+/-1.9 \mathrm{E}-07$ & $1.51 \mathrm{E}-07+1-2.1 \mathrm{E}-07$ & $1.51 \mathrm{E}-07+/ 2-1.5 \mathrm{E}-018$ & $1.51 \mathrm{E}-07+1-1.5 \mathrm{E}-08$ & $1.51 \mathrm{E}-07+/-1.5 \mathrm{E}-08$ & $1.51 \mathrm{E}-07+1-1.5 \mathrm{E}-08$ & $1.51 \mathrm{E}-07+/-1.5 \mathrm{E}-018$ & grams & Measurved by participating organization \\
\hline \begin{tabular}{|l|l} 
Cr Leached \\
Mn Lacheded \\
\end{tabular} & \begin{tabular}{|l|}
$1.41 E-06+-1.4 E-07$ \\
$200 E-07+-20 E-08$
\end{tabular} & 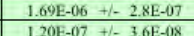 & 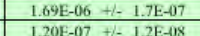 & 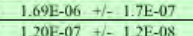 & $\frac{1.69 \mathrm{E}-06+1-1.7 \mathrm{E}-07}{1.20 \mathrm{E}-07+-1.2 \mathrm{E}-08}$ & \begin{tabular}{|l|}
$1.69 \mathrm{E}-06 \mathrm{6}+/-1.7 \mathrm{E}-07$ \\
$1.0 \mathrm{E}-07$ \\
\end{tabular} & \begin{tabular}{|l|l|}
$1.69 \mathrm{E}-06+1-1.7 \mathrm{E}-107$ \\
$1.20 \mathrm{E}-07$
\end{tabular} & $\begin{array}{c}\text { grams } \\
\text { gramsins }\end{array}$ & 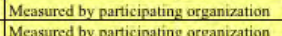 \\
\hline \begin{tabular}{|l} 
Mn Leachede \\
Co Leached \\
\end{tabular} & 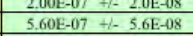 & $\frac{1.20 E-07+1-3.6 E-08}{1.12 E-06+1-5.0 E-08}$ & $\frac{1.20 E-07+1.1 .2 E-18}{1.12 E-06+1-1.1 E-07}$ & $\frac{1.20-0.07+1-1.2-108}{1.12 E-06+1-1.1 \mathrm{E}-07}$ & $\frac{1.20 E-07+1-1.2 E-018}{1.12 E-06+1-1.1 E-07}$ & $\begin{array}{l}1.20=-07+1-1.2-108 \\
1.12 E-06+1-1.11-07 \\
\end{array}$ & $\frac{1.20 E-07+1.1 .2 E-18}{1.12 E-06+1-1.1 E-07}$ & $\begin{array}{l}\text { grams } \\
\text { grams } \\
\end{array}$ & 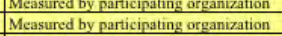 \\
\hline \begin{tabular}{|l|l} 
Ni Leached \\
\end{tabular} & $1.00 \mathrm{E}-06 \mathrm{06}+1-1.0 \mathrm{E}-07$ & $1.30 \mathrm{E}-06+1-7.0 \mathrm{E}-08$ & $1.30 \mathrm{E}-06+1-1.3 \mathrm{E}-07$ & $1.30 \mathrm{E}-06+1-1.3 \mathrm{E}-07$ & $1.30 \mathrm{E}-06+1-1.3 \mathrm{E}-07$ & $1.30 \mathrm{E}-06 \mathrm{t}+1-1.3 \mathrm{E}-07$ & $1.30 \mathrm{E}-06+1-1.3 \mathrm{E}-07$ & grams & Measurued by participating organizization \\
\hline \begin{tabular}{|l|l|l|l|l|l} 
A Leached \\
\end{tabular} & $1.40 E-05+h-1.4 \mathrm{E}-106$ & $1.96 \mathrm{E}-05+1-2.0 \mathrm{E}-06$ & $1.96 E-05+1-2.00-06$ & $1.96 \mathrm{E}-05+1-2.0 \mathrm{E}-06$ & $1.96 E-05+1-2.0 E-16$ & $\begin{array}{l}1.96 \mathrm{E}-05+1-2.0 \mathrm{E}-06 \\
.90607\end{array}$ & $1.96 \mathrm{E}-05+1-2.0 \mathrm{E}-06$ & grams & Measured by participating organization \\
\hline \begin{tabular}{|l|l|} 
TiLeached \\
SLected
\end{tabular} & $4.96 \mathrm{E}-06+1-5.0 \mathrm{E}-07$ & 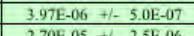 & $3.97 \mathrm{E}-06+1-4.0 \mathrm{0E}-177$ & $3.97 \mathrm{~T}-06+1-4.0 \mathrm{E}-07$ & $3.97 \mathrm{E}-06+1-4.0 \mathrm{E}-07$ & 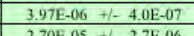 & $3.97 \mathrm{E}-06+1-4.0 \mathrm{E}-177$ & grams & participating organizzation \\
\hline VLeached & $2.25 E-05+l-2.3 E-106$ & $2.70 \mathrm{E}-05+1-2.5 \mathrm{E}-06$ & $2.70 E-05+1.2 .7 E-166$ & $\frac{2.70 E-05+h-2.7 E-06}{\text { Combinind Impurity } 1}$ & $\frac{1}{\text { ata }} 2.70 \mathrm{E}-0.05+1-2.7 \mathrm{E}-166$ & $2.70 \mathrm{E}-05+1-2.7 \mathrm{E}-06$ & $2.70 E-05+1-2.7 E-16$ & & ating organization \\
\hline \begin{tabular}{|l} 
Total Fe Leached \\
\end{tabular} & $3.78 \mathrm{E}-06+1-2.67 \mathrm{E}-07$ & $3.02 \mathrm{E}-07+1-2.94 \mathrm{E}-07$ & $2.14 E-08$ & $3.02 \mathrm{E}-07+1-2.14 \mathrm{E}-08$ & $3.02 E-07+1-2.14 E-08$ & 3.0 & 3.02 & grams & Calculated by spreadsheet \\
\hline \begin{tabular}{|l} 
Total Cr Leached \\
\end{tabular} & $2.82 \mathrm{E}-06+1-1.99 \mathrm{E}-07$ & $3.38 \mathrm{E}-06+1-3.99 \mathrm{E}-07$ & $3.38 \mathrm{E}-066+1-2.39 \mathrm{E}-07$ & $3.38 \mathrm{E}-066+1-2.39 \mathrm{E}-07$ & $3.38 \mathrm{E}-06+1-2.39 \mathrm{E}-07$ & $06+1-2$ & $3.38 \mathrm{E}-06+1-2$ & grams & Calculated by spreadsheet \\
\hline \begin{tabular}{|l} 
Total Mn Leached \\
\end{tabular} & $4.00 \mathrm{E}-07+l-2.83 \mathrm{E}-08$ & $2.40 \mathrm{E}-07+1-5.09 \mathrm{E}-08$ & $2.40 \mathrm{E}-07+1-1.70 \mathrm{E}-08$ & $2.40 \mathrm{E}-07+1-1.70 \mathrm{E}-08$ & $1.70 E-08$ & $2.40 \mathrm{E}-07+1-1.70 \mathrm{E}-08$ & $2.40 \mathrm{E}-07+1-1.70 \mathrm{E}-018$ & grams & by spreadshect \\
\hline 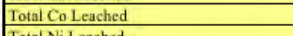 & $1.12 \mathrm{E}-06+1-7.92 \mathrm{E}-08$ & $2.24 \mathrm{E}-06+1-7.13 \mathrm{E}-08$ & $2.24 E-06+1-1.58 E-07$ & $\frac{06+1-1.58 \mathrm{E}-07}{06-07}$ & $2.24 \mathrm{E}-06+1-1.58 \mathrm{E}-07$ & 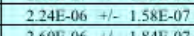 & $2.24 \mathrm{E}-06+1-1.58 \mathrm{E}-07$ & grams & Calculated by spreadsheet \\
\hline $\begin{array}{l}\text { Total I i Leached } \\
\text { Totat Al Leached }\end{array}$ & \begin{tabular}{|c|}
$2.00 E-06+l-1.41 E-07$ \\
$2.80 E-05+1-1.98 E-06$
\end{tabular} & $\frac{2.60 \mathrm{E}-06+1-9.90 \mathrm{EE}-08}{3.92 \mathrm{E}-05+1-2.77 \mathrm{E}-06}$ & $\frac{2.60 E-06+1-1.84 \mathrm{E}-07}{3.92 \mathrm{E}-05+1-2.77 \mathrm{E}-06}$ & 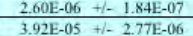 & $\frac{2.60 E-06+1-1.47 \mathrm{E}-07}{3.92 \mathrm{E}-05+1-2.27 \mathrm{E}-06}$ & 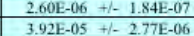 & 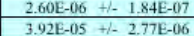 & $\frac{\text { grams }}{\text { yrams }}$ & 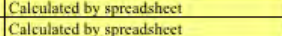 \\
\hline Total Ti Leached & $9.92 \mathrm{E}-06 \mathrm{t}+\mathrm{l}-7.01 \mathrm{E}-07$ & $7.94 \mathrm{E}-06+1-7.01 \mathrm{E}-07$ & $7.94 \mathrm{E}-06+1-5.61 \mathrm{E}-010$ & $7.94 \mathrm{E}-06 \mathrm{t}+\mathrm{k}-5.61 \mathrm{E}-07$ & $7.94 \mathrm{E}-06+1-5.61 \mathrm{E}-07$ & 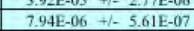 & $7.94 \mathrm{E}-06+1-5.61$ & grams & $\begin{array}{l}\mid \\
\text { Calculated by spreadsheet }\end{array}$ \\
\hline $\begin{array}{l}\text { Total V Leached } \\
\end{array}$ & $4.50 \mathrm{E}-05$ +/ $-3.18 \mathrm{EE}-06$ & $5.40 \mathrm{E}-05+1-3.50 \mathrm{E}-06$ & $5.40 \mathrm{E}-05+1-3.82 \mathrm{E}-06$ & $5.40 \mathrm{E}-05 \quad+1-3.82 \mathrm{E}-06$ & $5.40 \mathrm{E}-05+/-3.82 \mathrm{E}-06$ & $5.40 \mathrm{E}-05+/-3.82 \mathrm{E}-06$ & $5.40 \mathrm{E}-05+1-3.82 \mathrm{E}-06$ & grams & Calculated by spreadshicet \\
\hline
\end{tabular}




\section{Appendix C. OPTICAL IMAGES OF SIMULATED PRE-BURN LEACH DEFECTS IN DUN500S-10A PARTICLES BEFORE REMOVAL FROM THE CRYSTALBOND EPOXY}

Each particle is shown as it appeared after impact with the ram (see Figure 1). Cracks in the Crystalbond epoxy provided visible feedback regarding the extent of the fracturing in the TRISO coating due to the impact of the ram on the exposed top of the particle and were used for initial selection of particles (Table 3) prior to x-ray confirmation of the required crack microstructure (Appendix D).
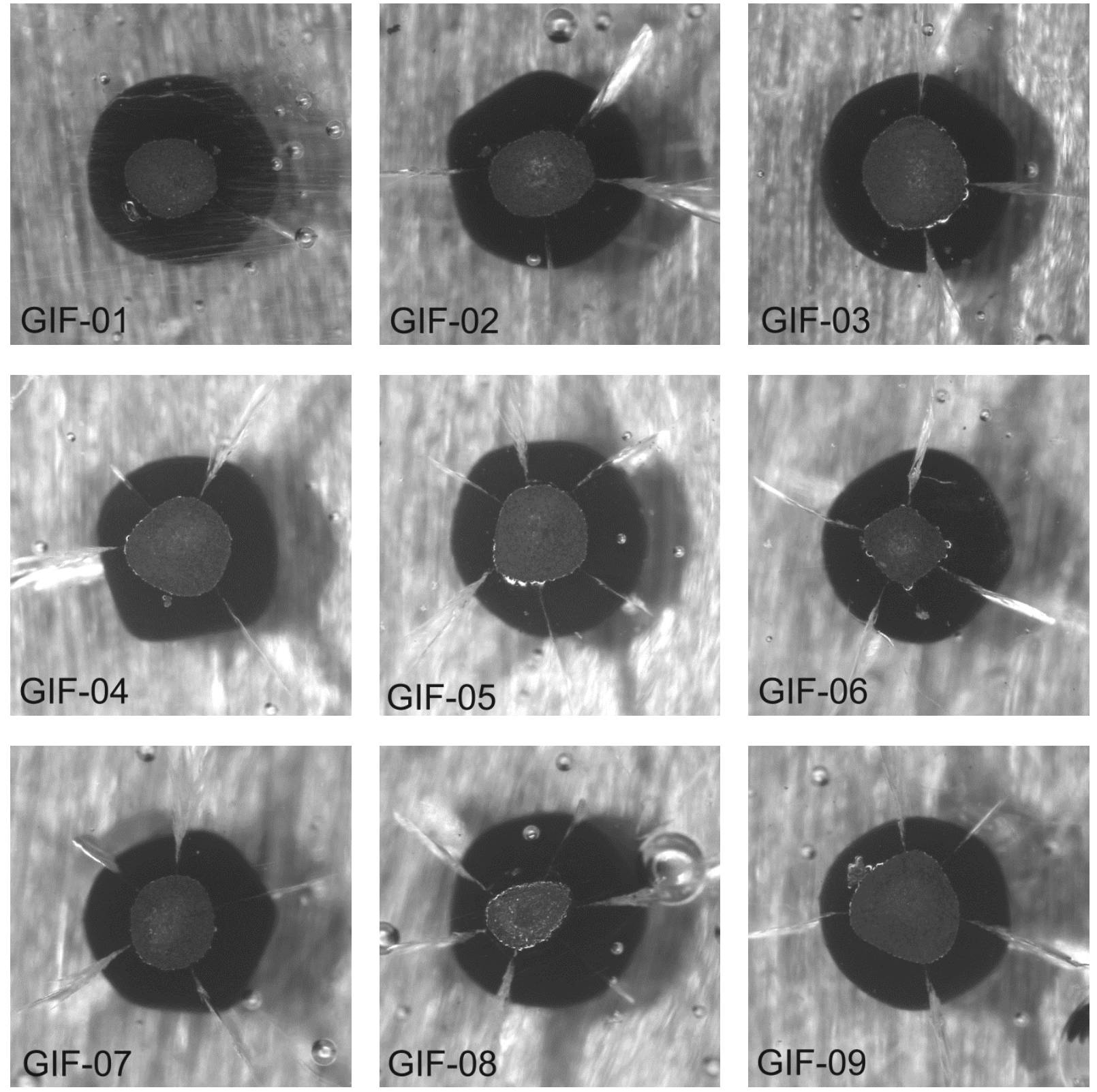

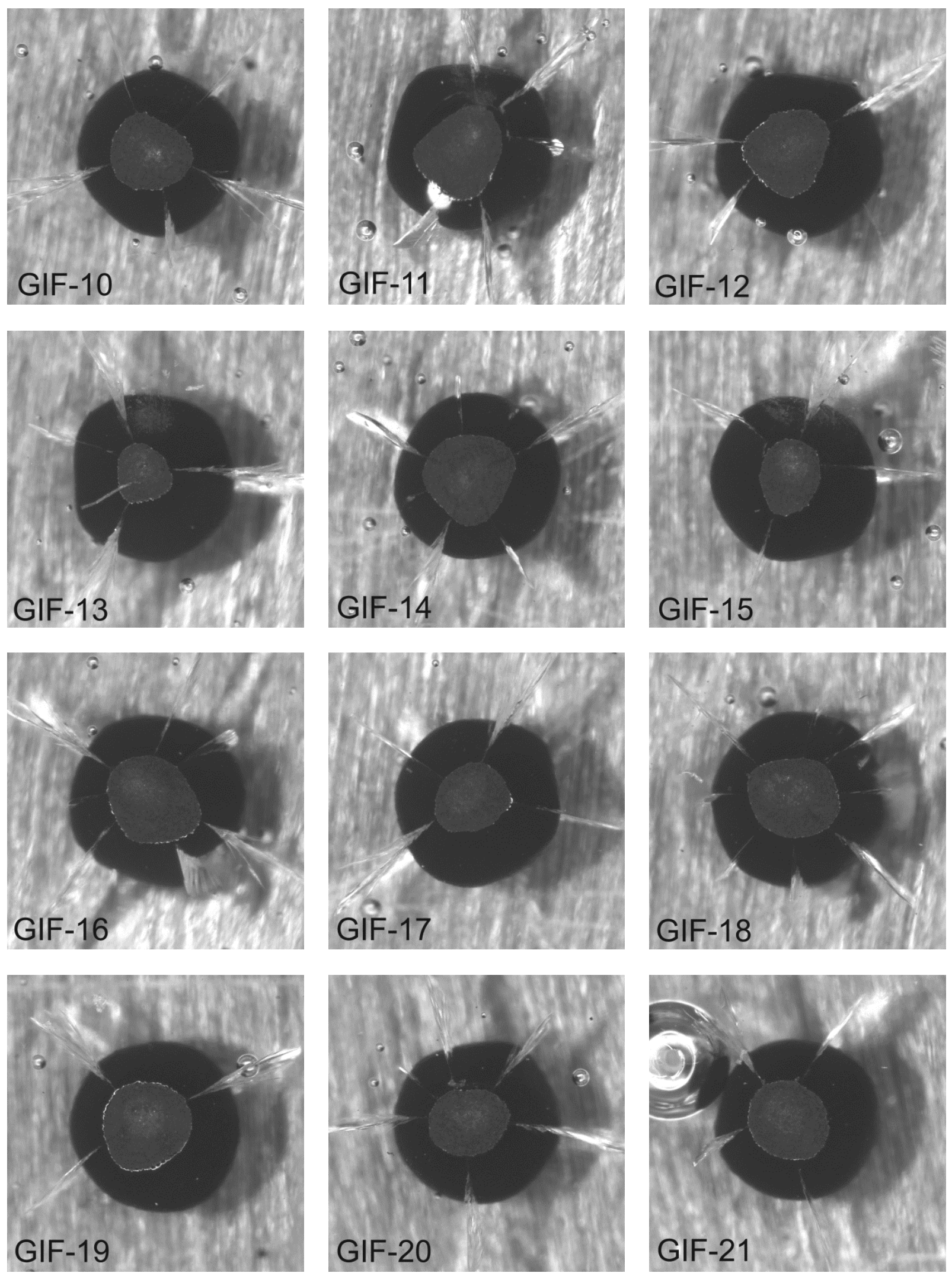

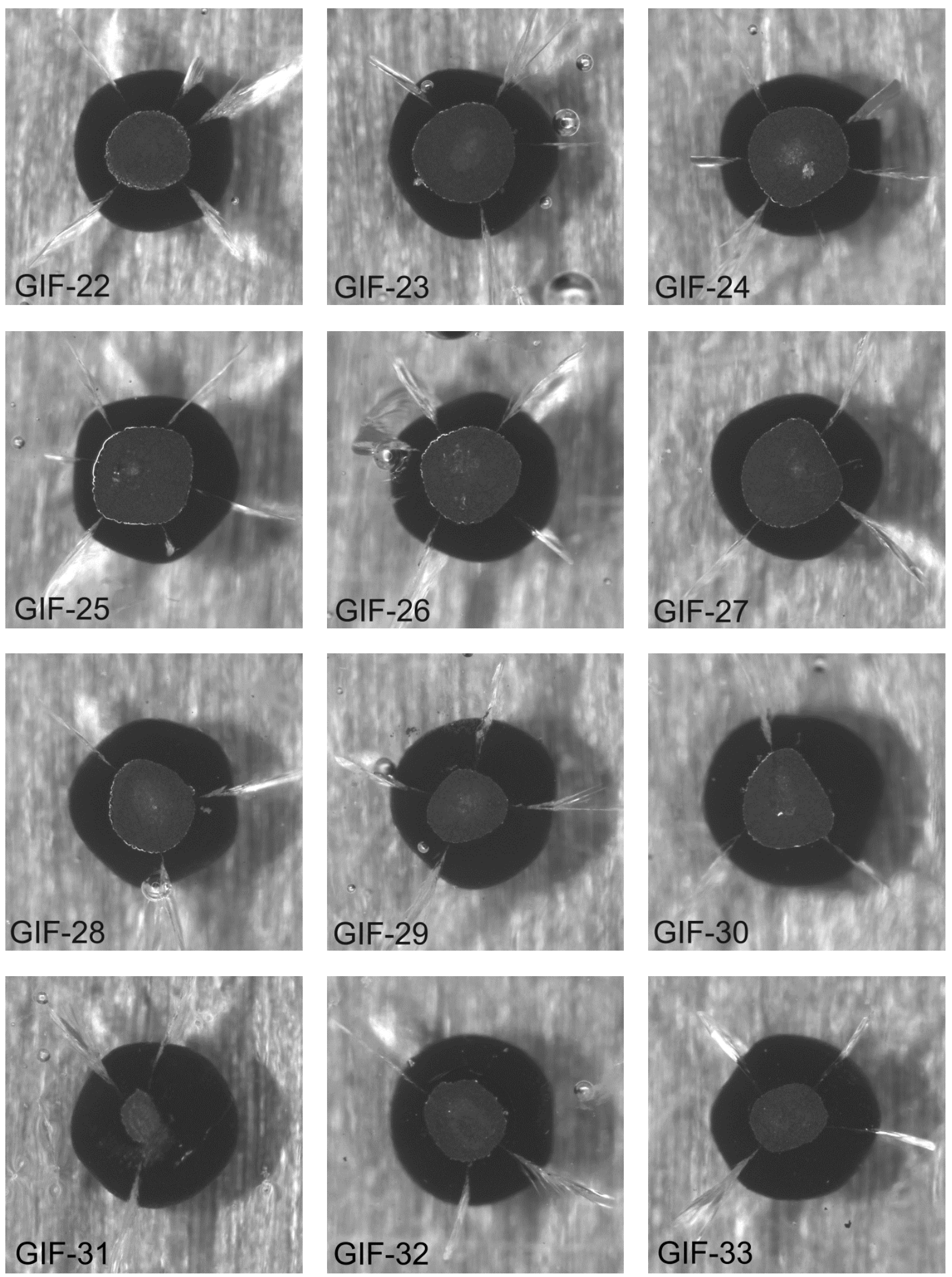

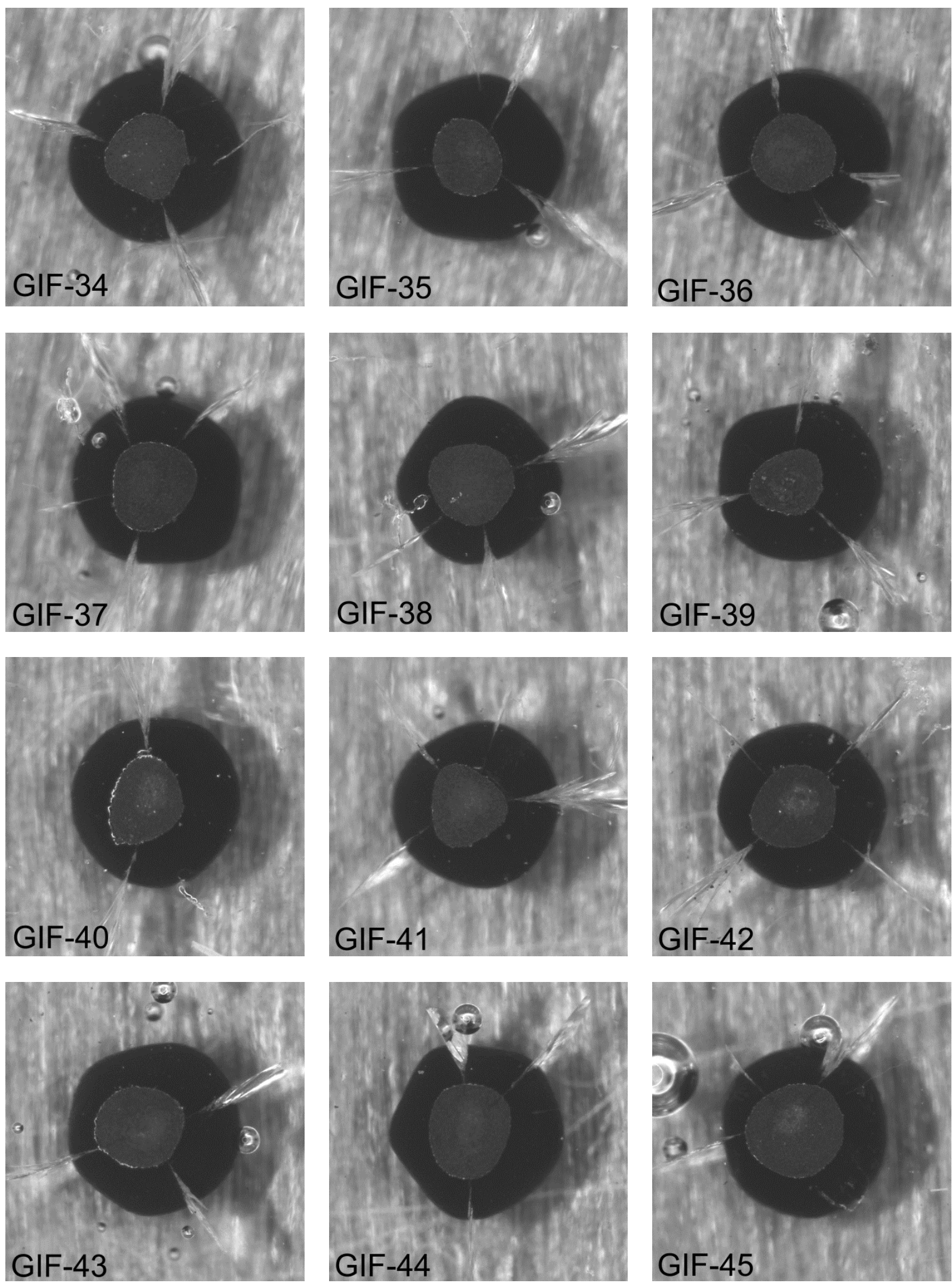
ORNL/TM-2015/722-R2
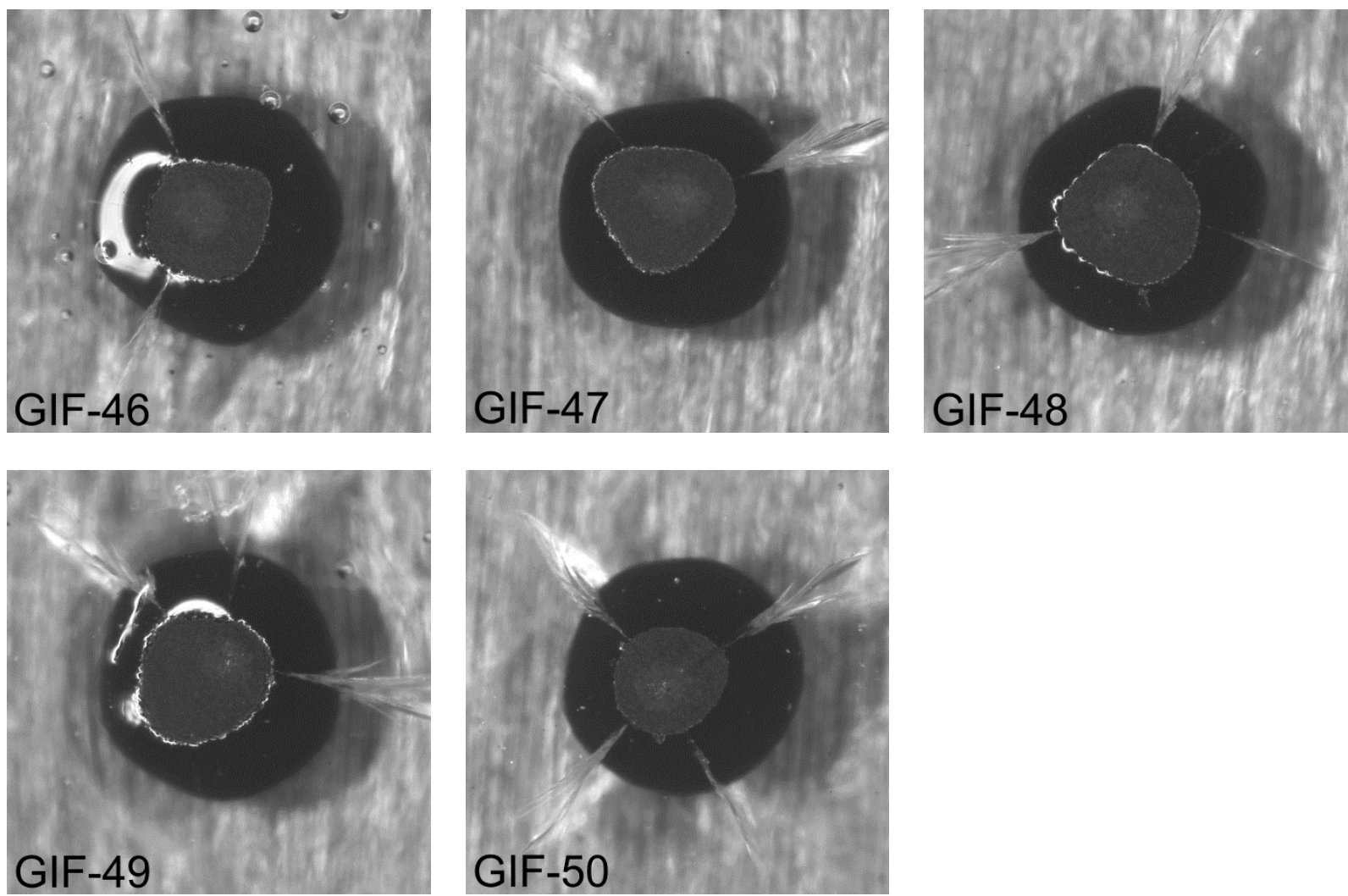


\section{Appendix D. X-RAY TOMOGRAPHS OF SIMULATED PRE-BURN LEACH DEFECTS IN DUN500S-10A PARTICLES AFTER REMOVAL FROM THE CRYSTALBOND EPOXY}

X-ray tomography was performed on all particles selected for use in the round robin experiment after removal of each particle from the Crystalbond (as shown in Appendix A) by dissolving the epoxy in acetone. The location of the TRISO layer fractures visible in each tomograph is indicated by an arrow.

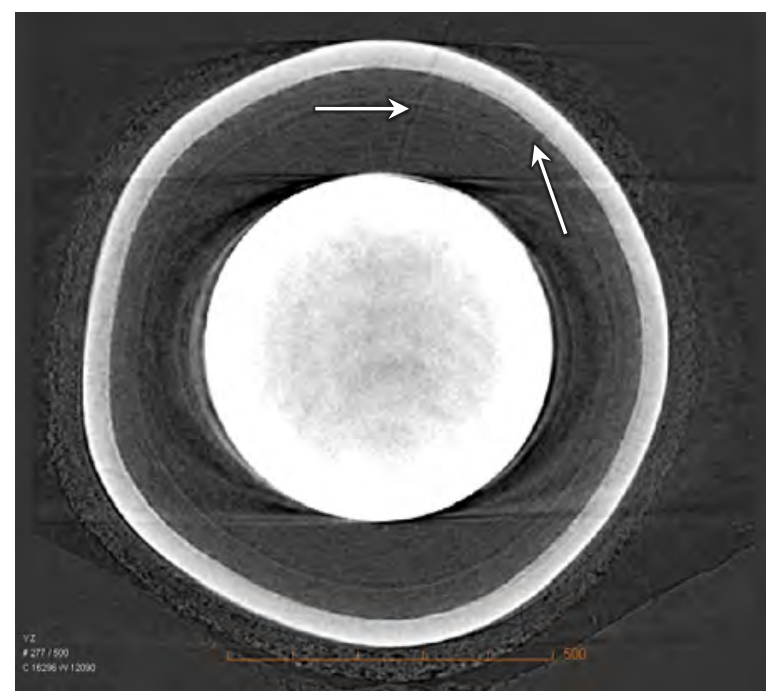

GIF-02

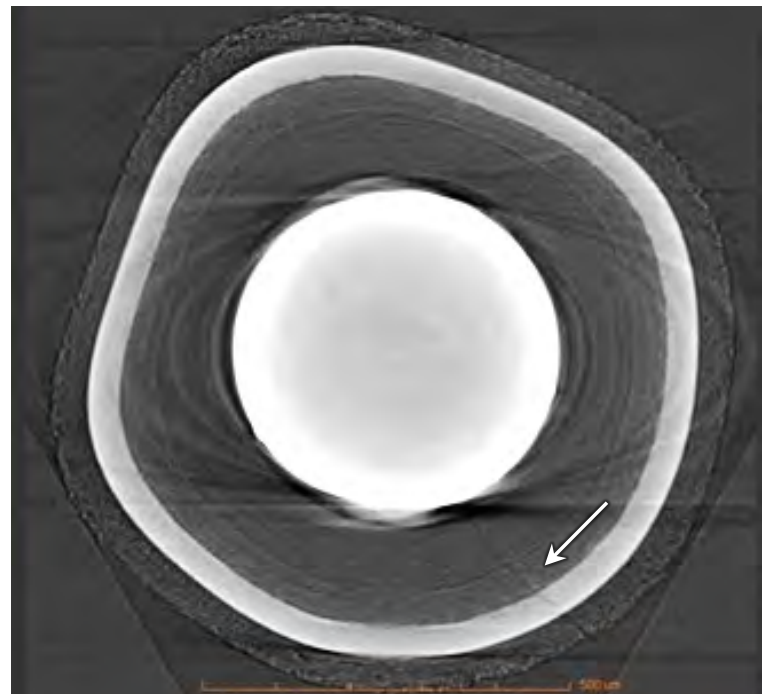

GIF-04

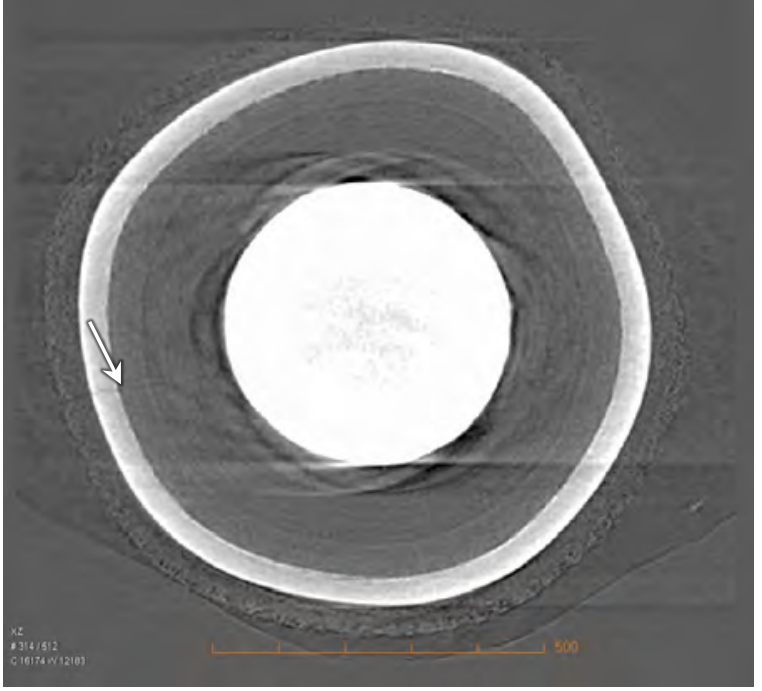

GIF-03

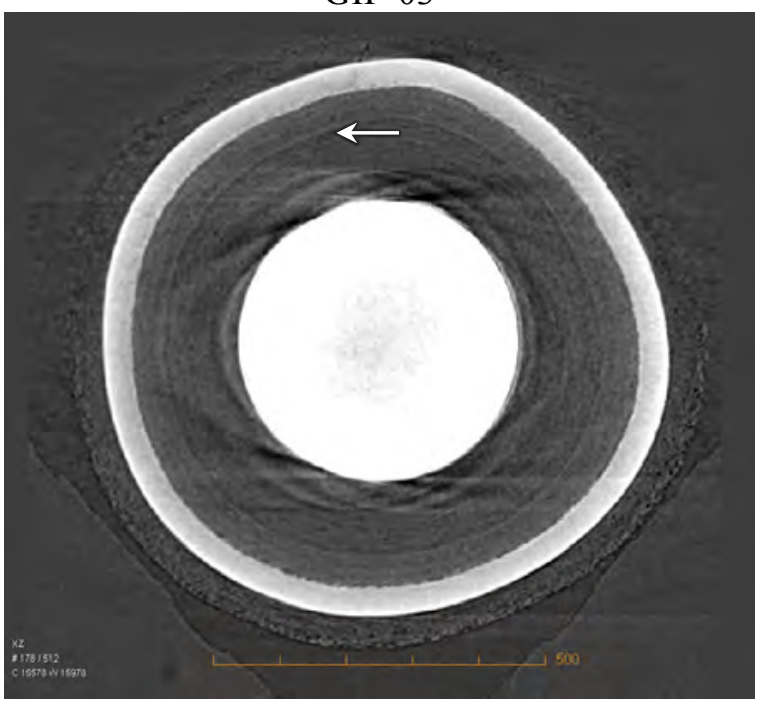

GIF-06 
ORNL/TM-2015/722-R2

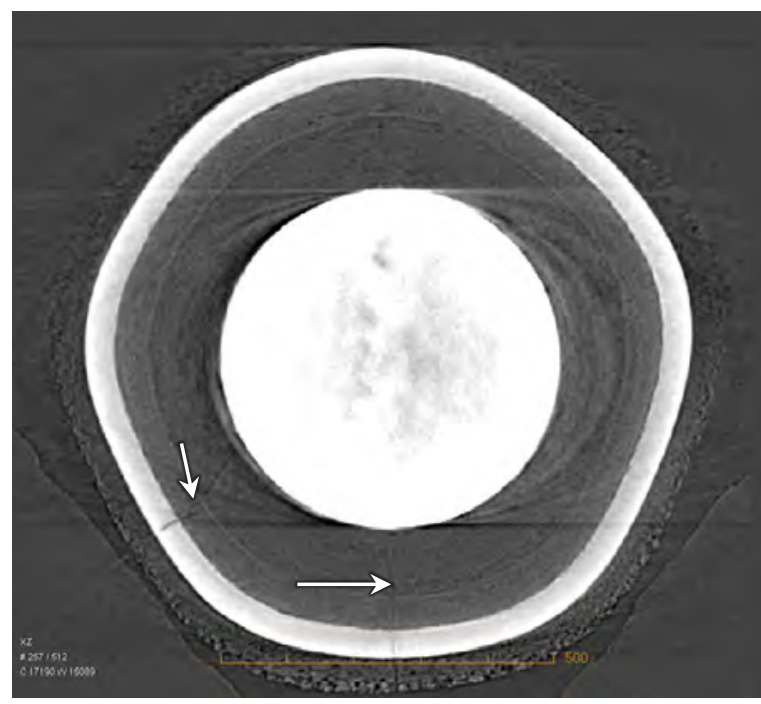

GIF-07

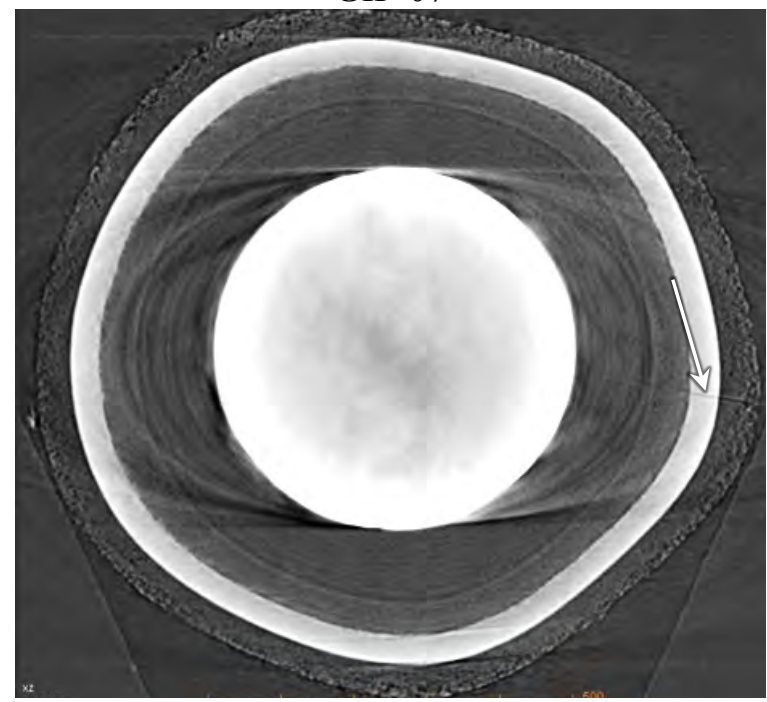

GIF-12

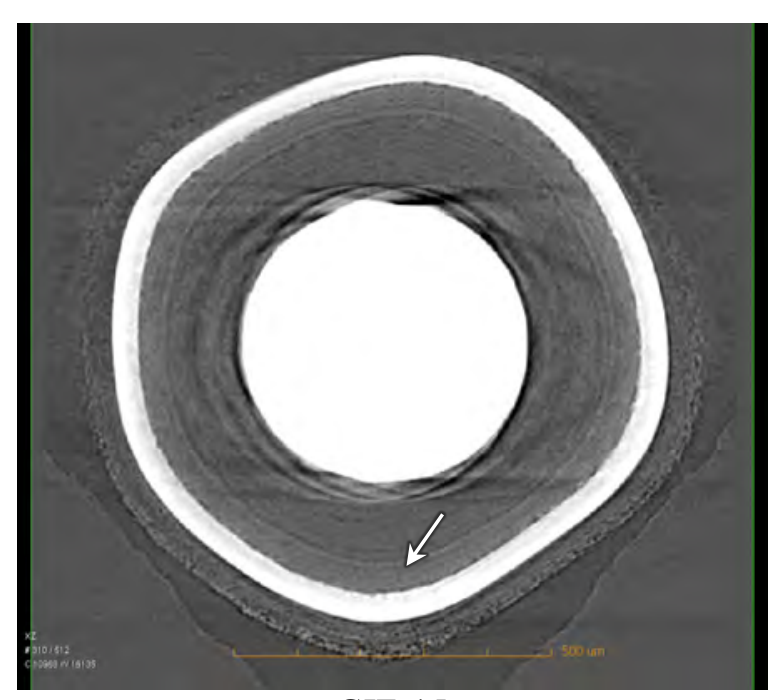

GIF-15

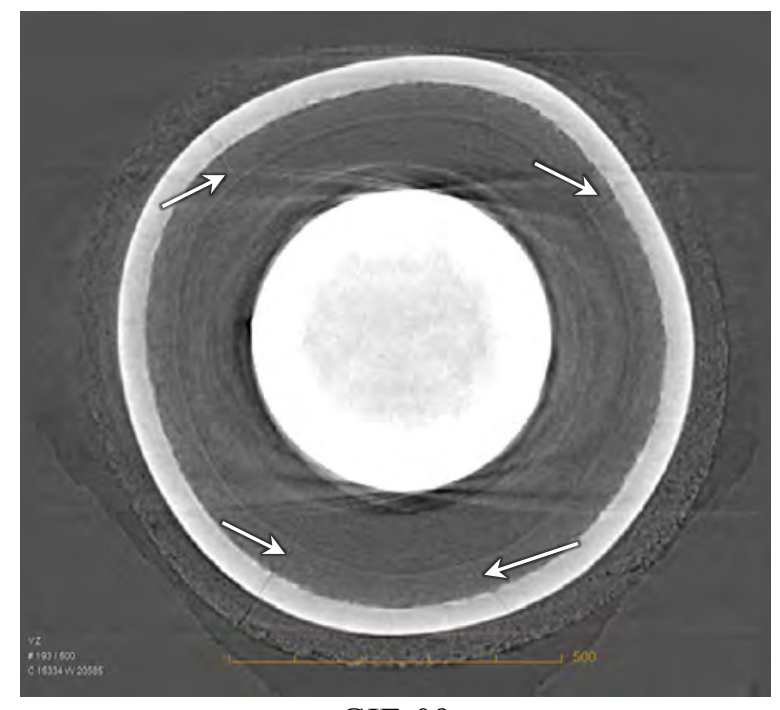

GIF-09

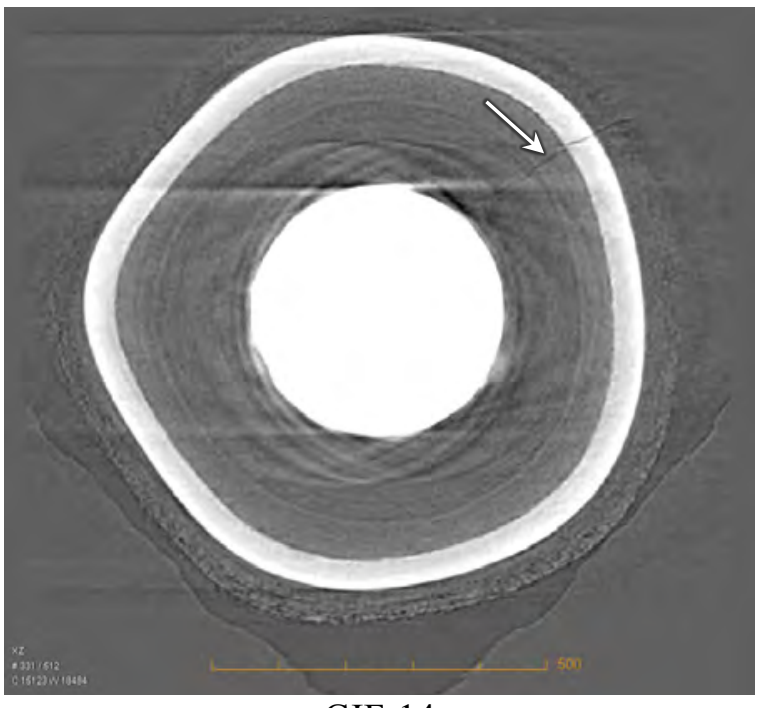

GIF-14

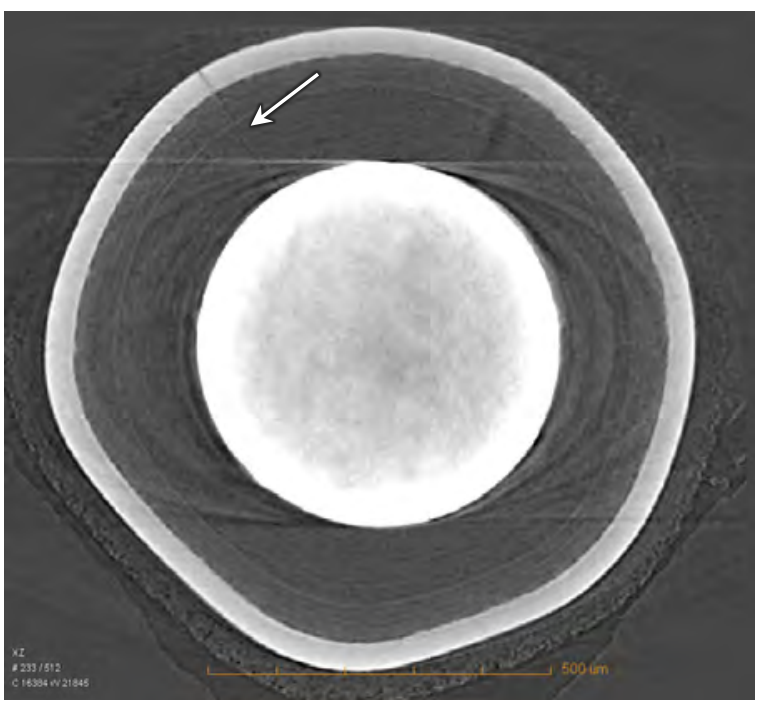

GIF-17 


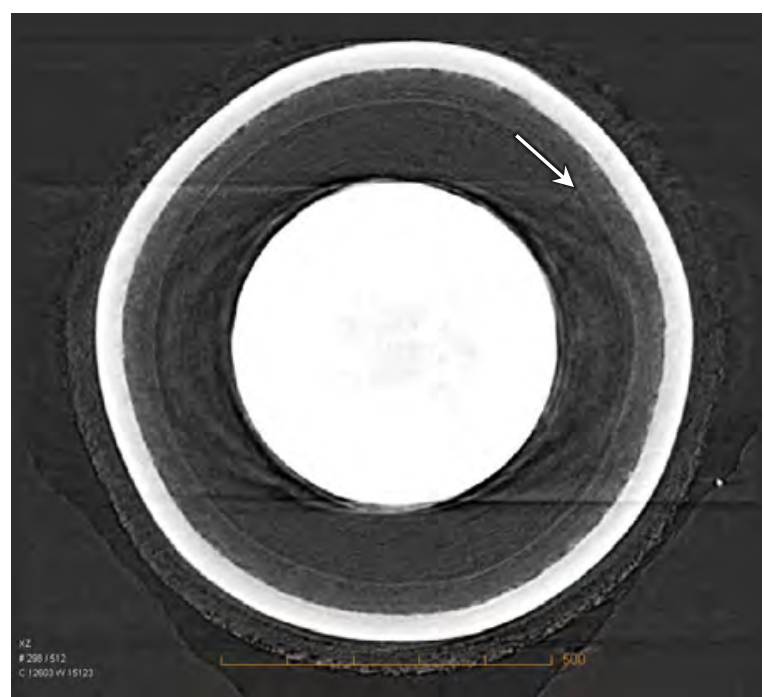

GIF-19

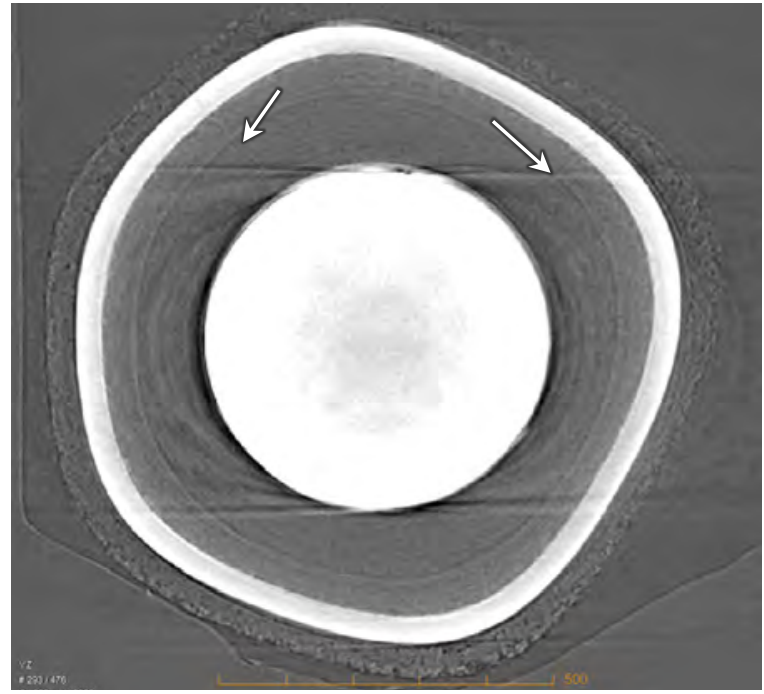

GIF-28

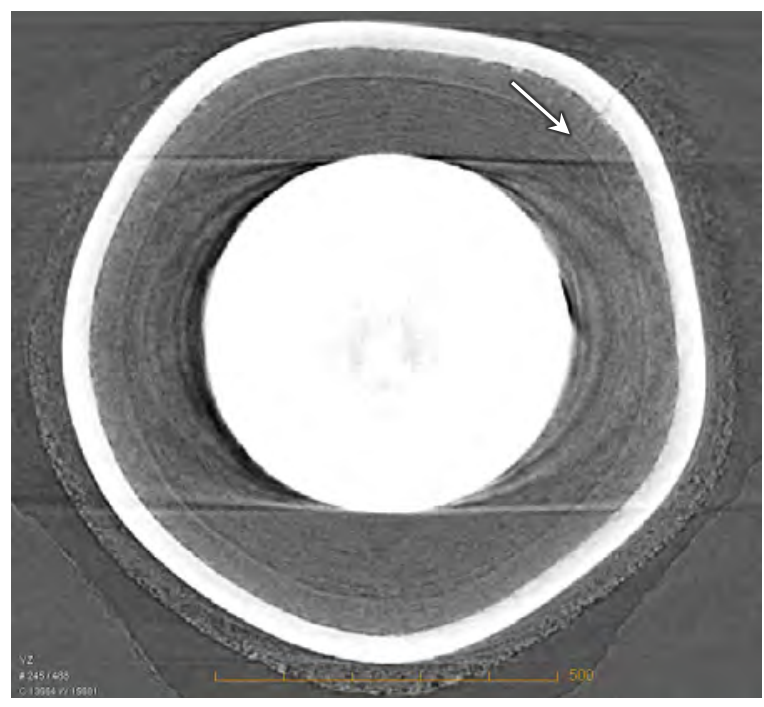

GIF-30

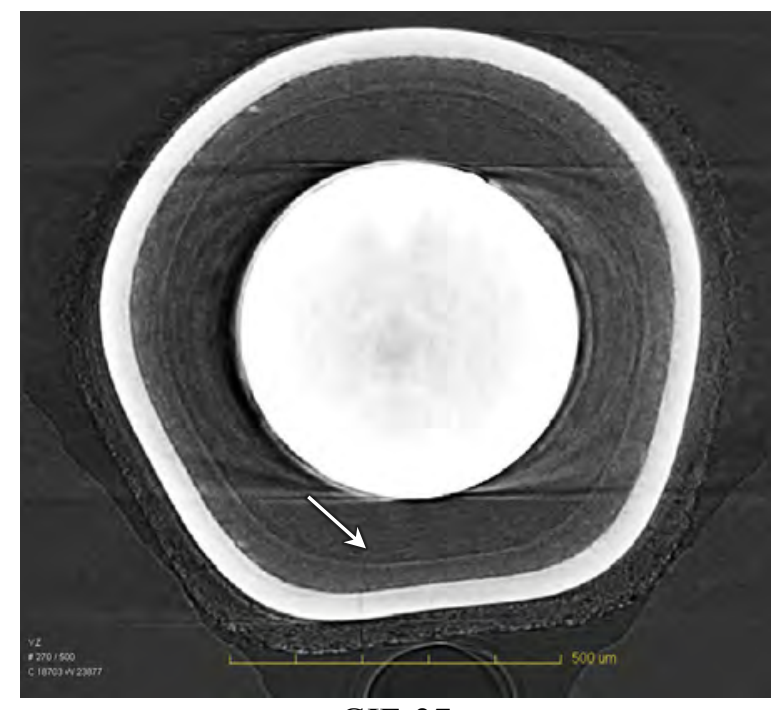

GIF-27

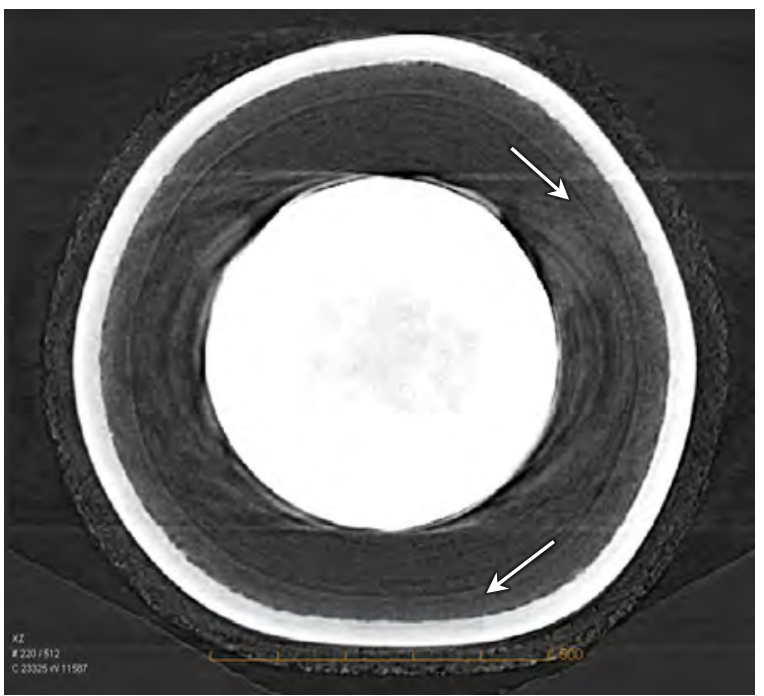

GIF-29

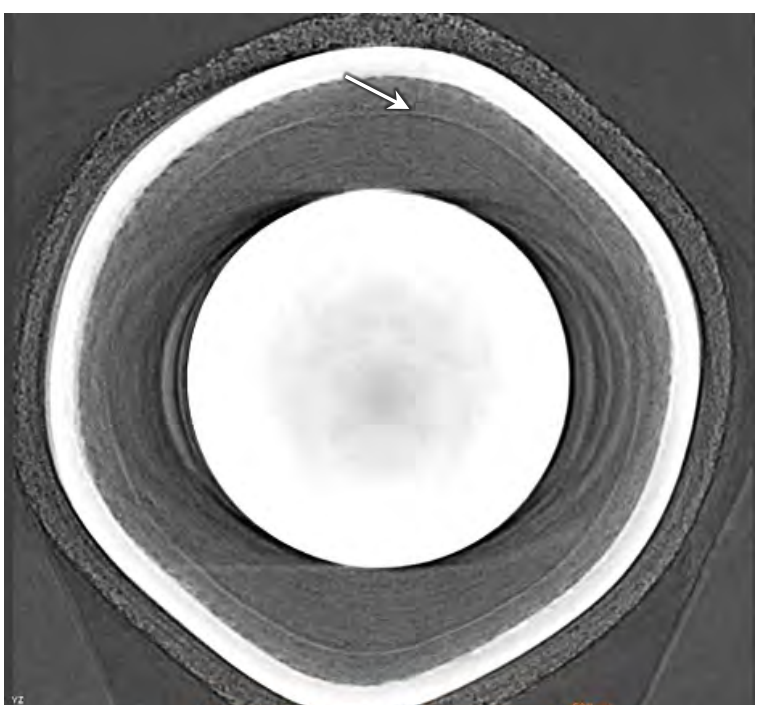

GIF-33 


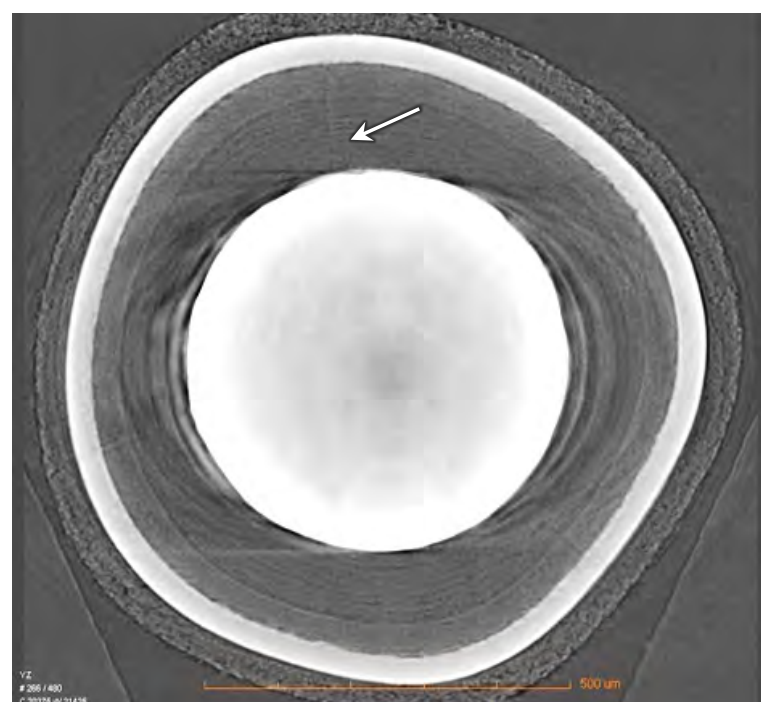

GIF-34

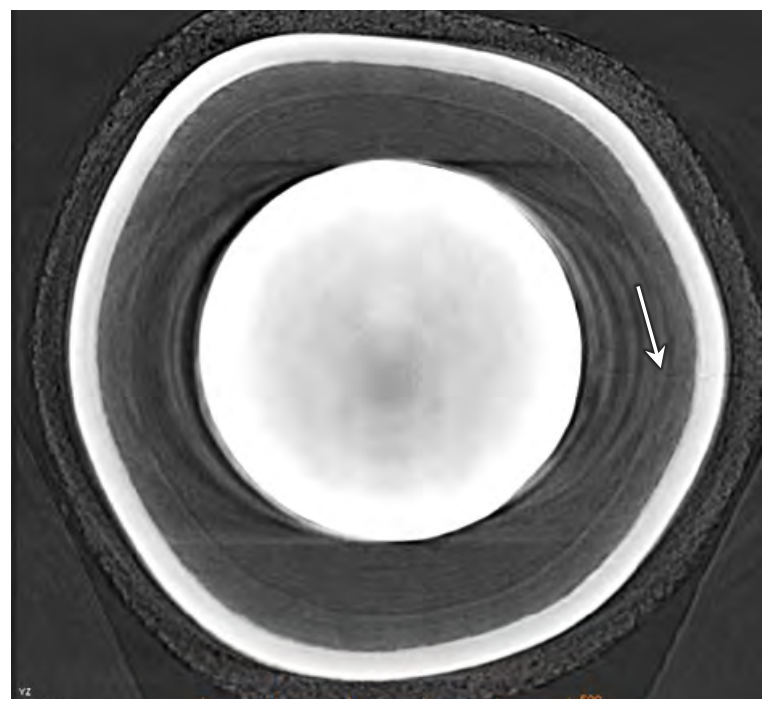

GIF-36

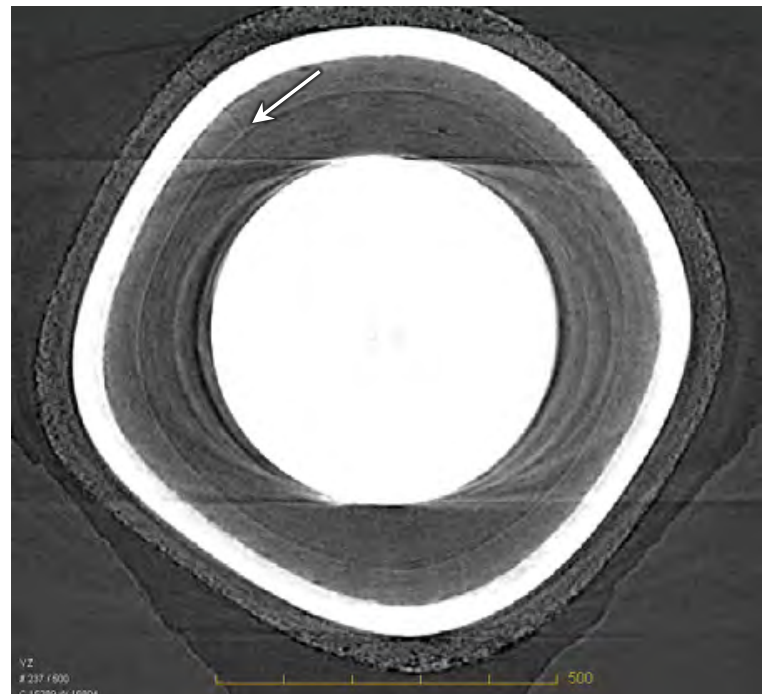

GIF-38

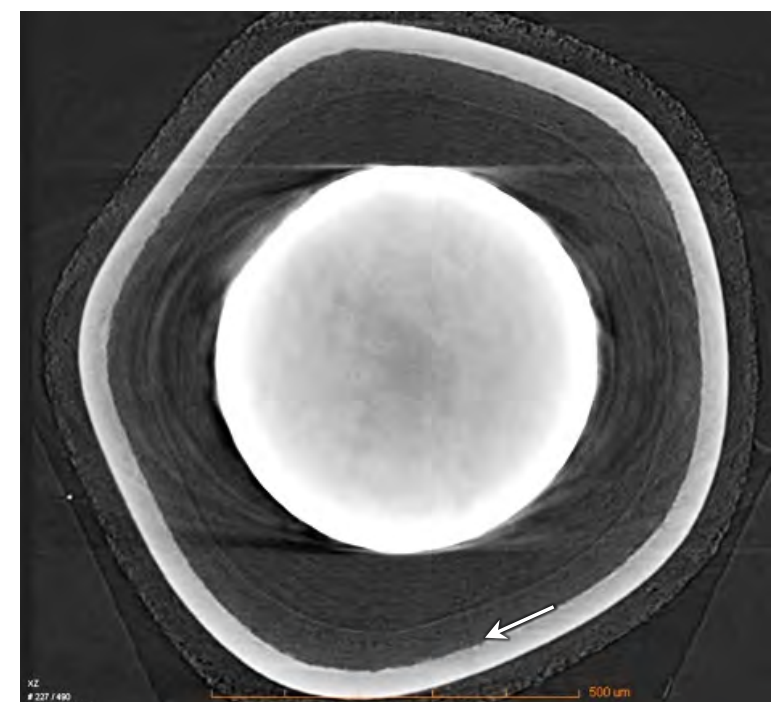

GIF-35

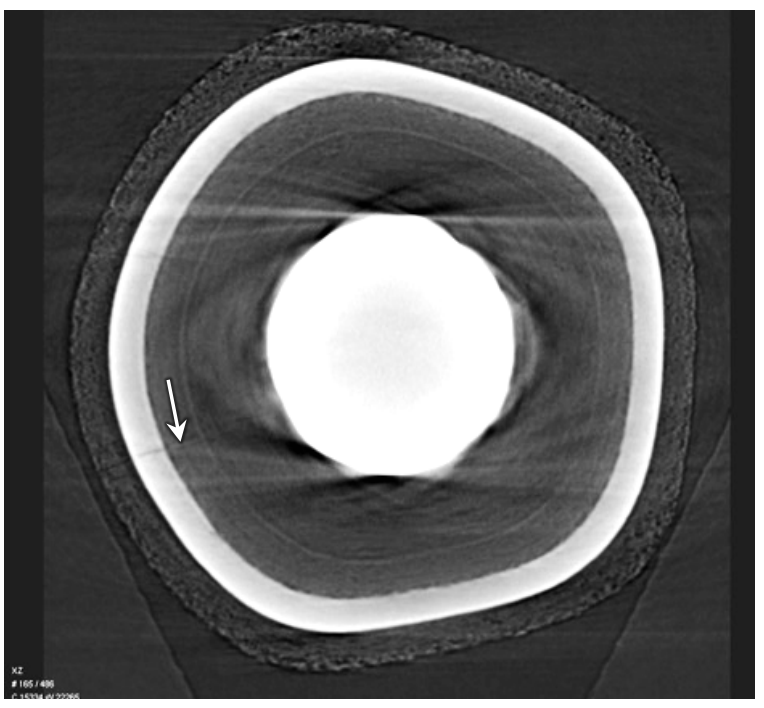

GIF-37

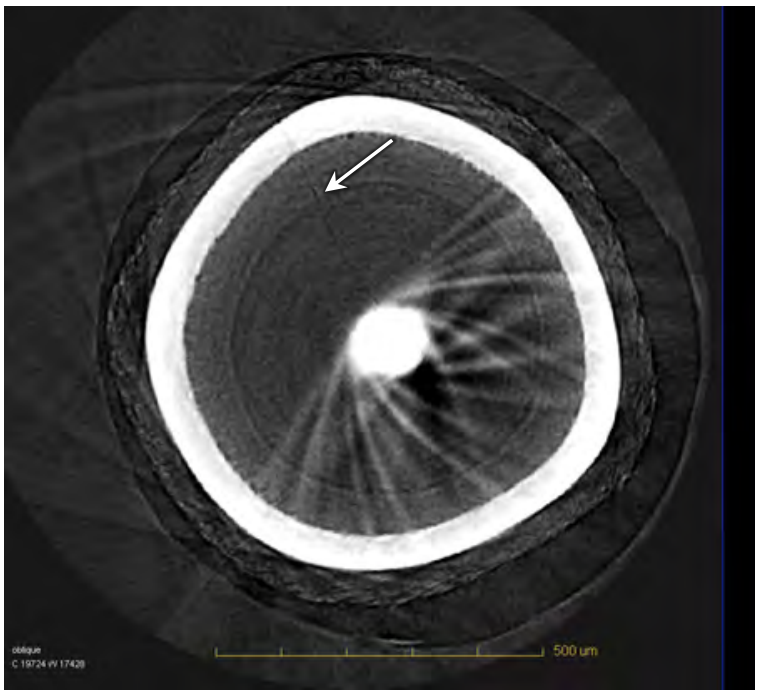

GIF-39 (oblique tomograph) 


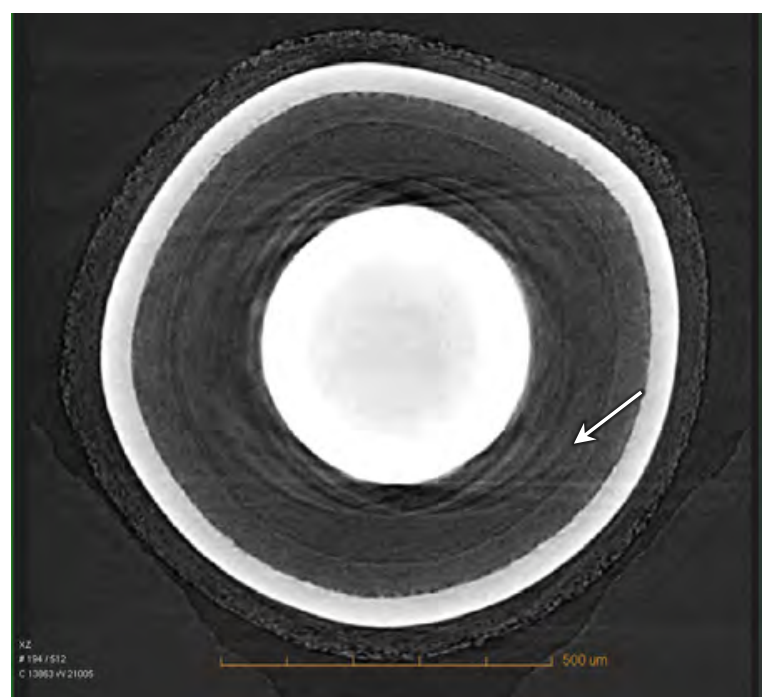

GIF-41

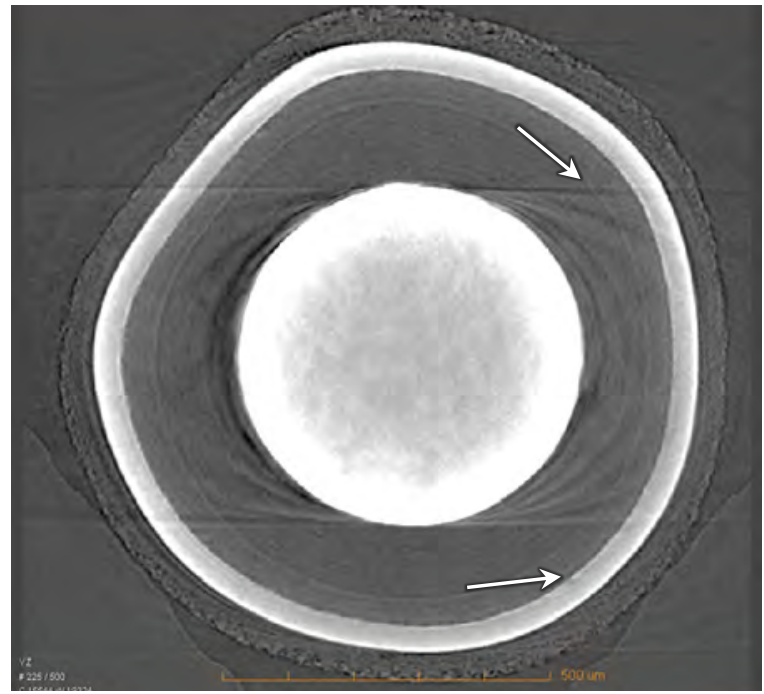

GIF-43

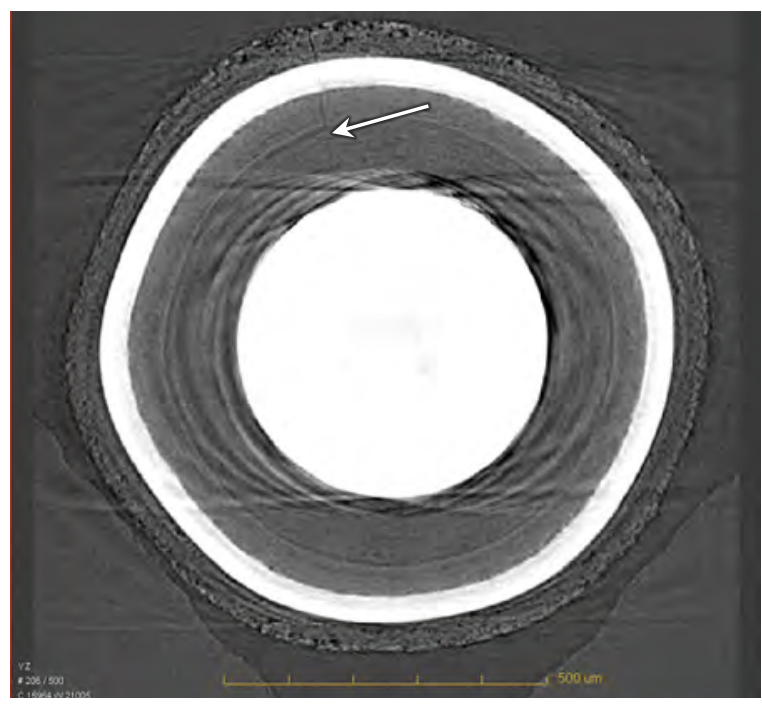

GIF-49

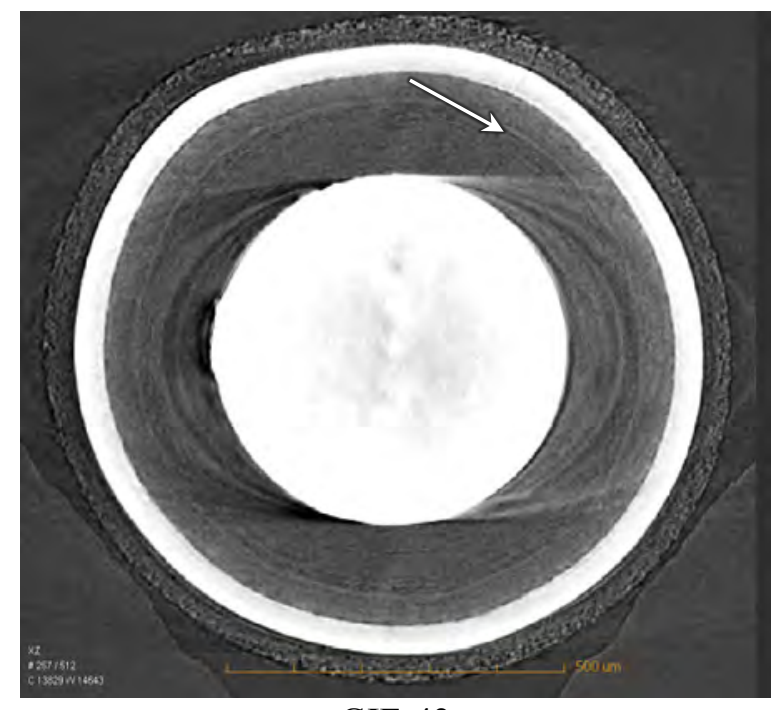

GIF-42

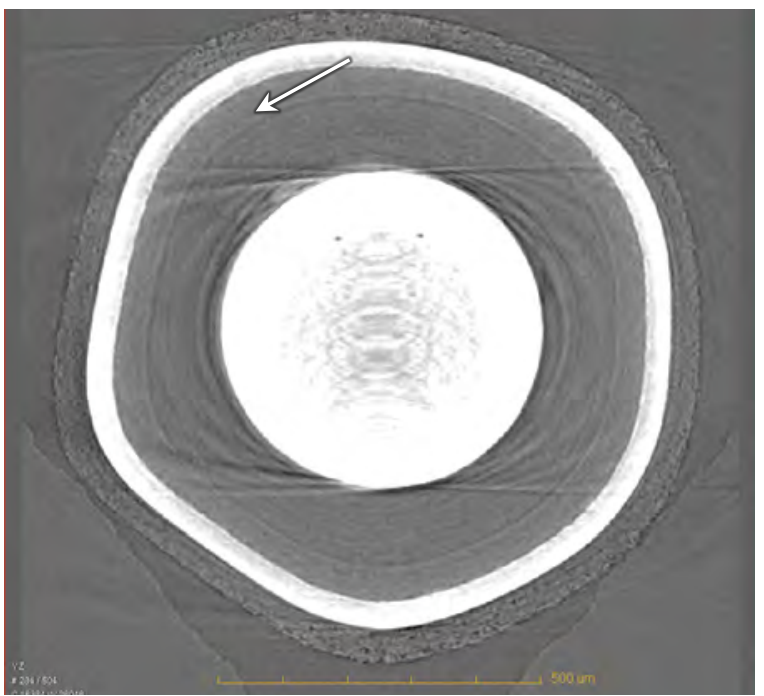

GIF-44

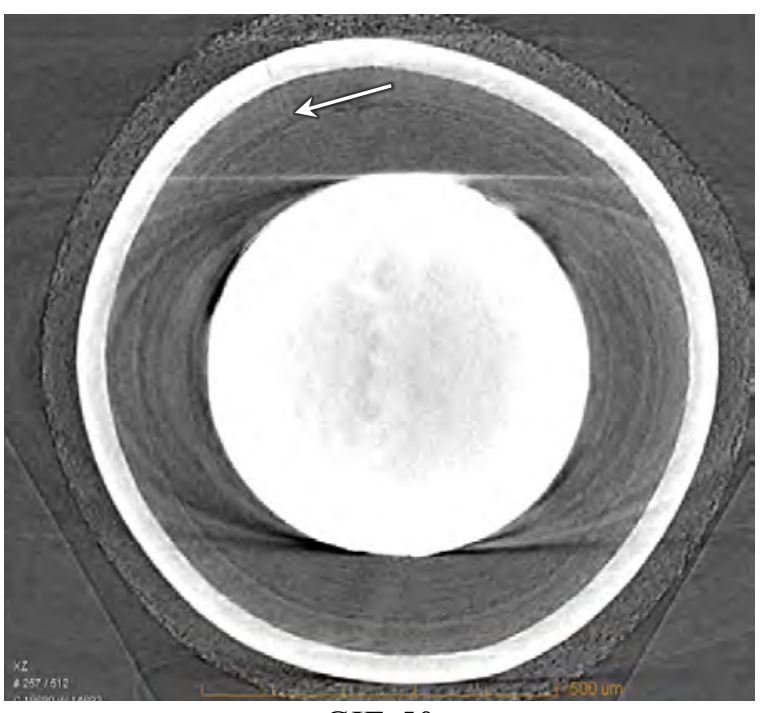

GIF-50 


\section{Appendix E. SEM IMAGES AND X-RAY RADIOGRAPHS OF SIMULATED POST-BURN LEACH DEFECTS IN DUN500S-10A PARTICLES}

Secondary-electron images (left) show the side and bottom of the hole through the SiC layer after completion of the milling process in the FIB to expose the IPyC layer. X-ray radiographs (right) show a vertical cross section through the crater at an optimized angle. A spot of platinum deposited at the bottom of each crater can be seen as a lighter contrast circle in the SEM images and as a dark spot in the radiographs. The mottled appearance of the IPyC material at the bottom of each crater (evident in the SEM images) and the vertical location of the platinum spot (evident in the radiographs) provide evidence of the successful exposure of the IPyC layer in each particle without penetrating more than $10 \mu \mathrm{m}$ into the layer.
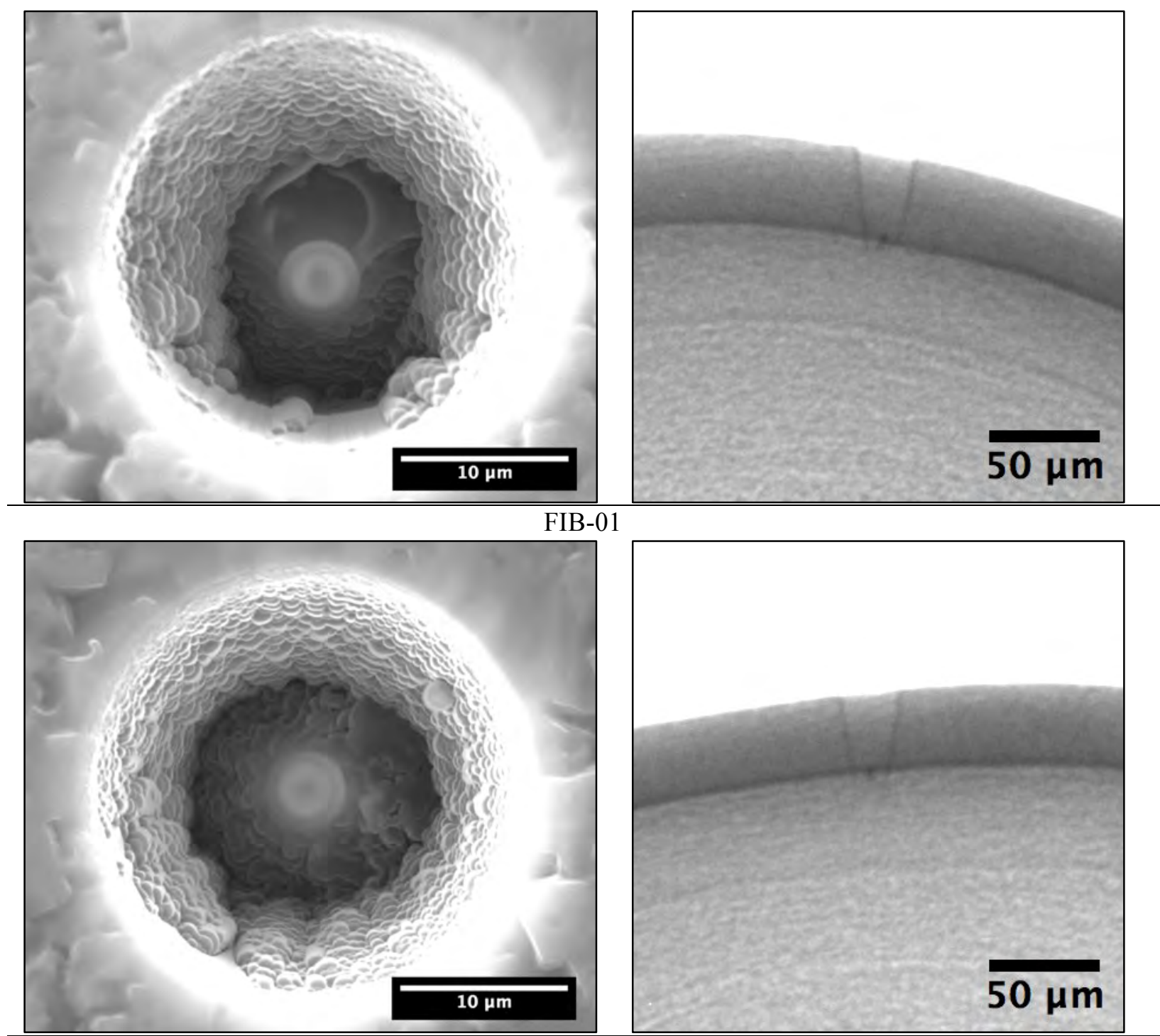

FIB-02 
ORNL/TM-2015/722-R2

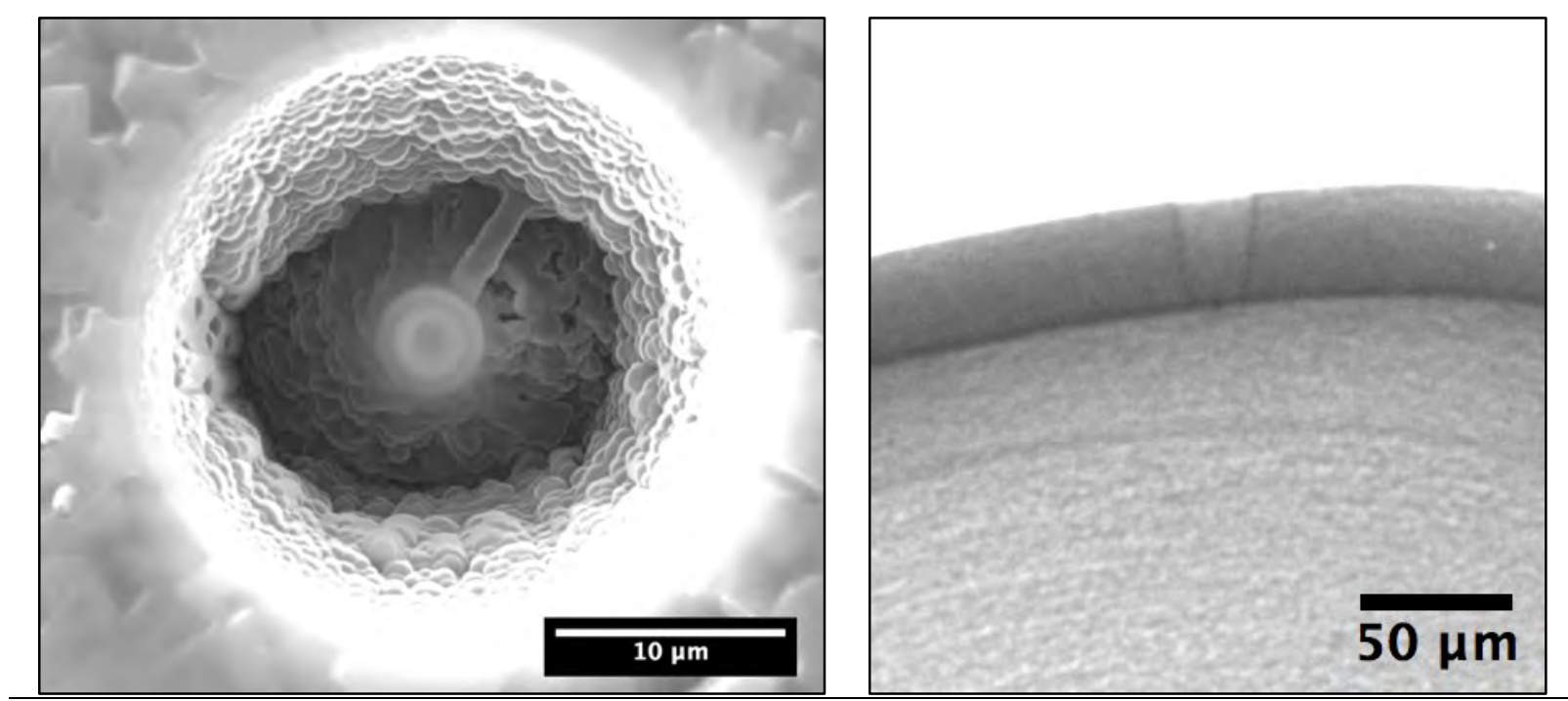

FIB-03
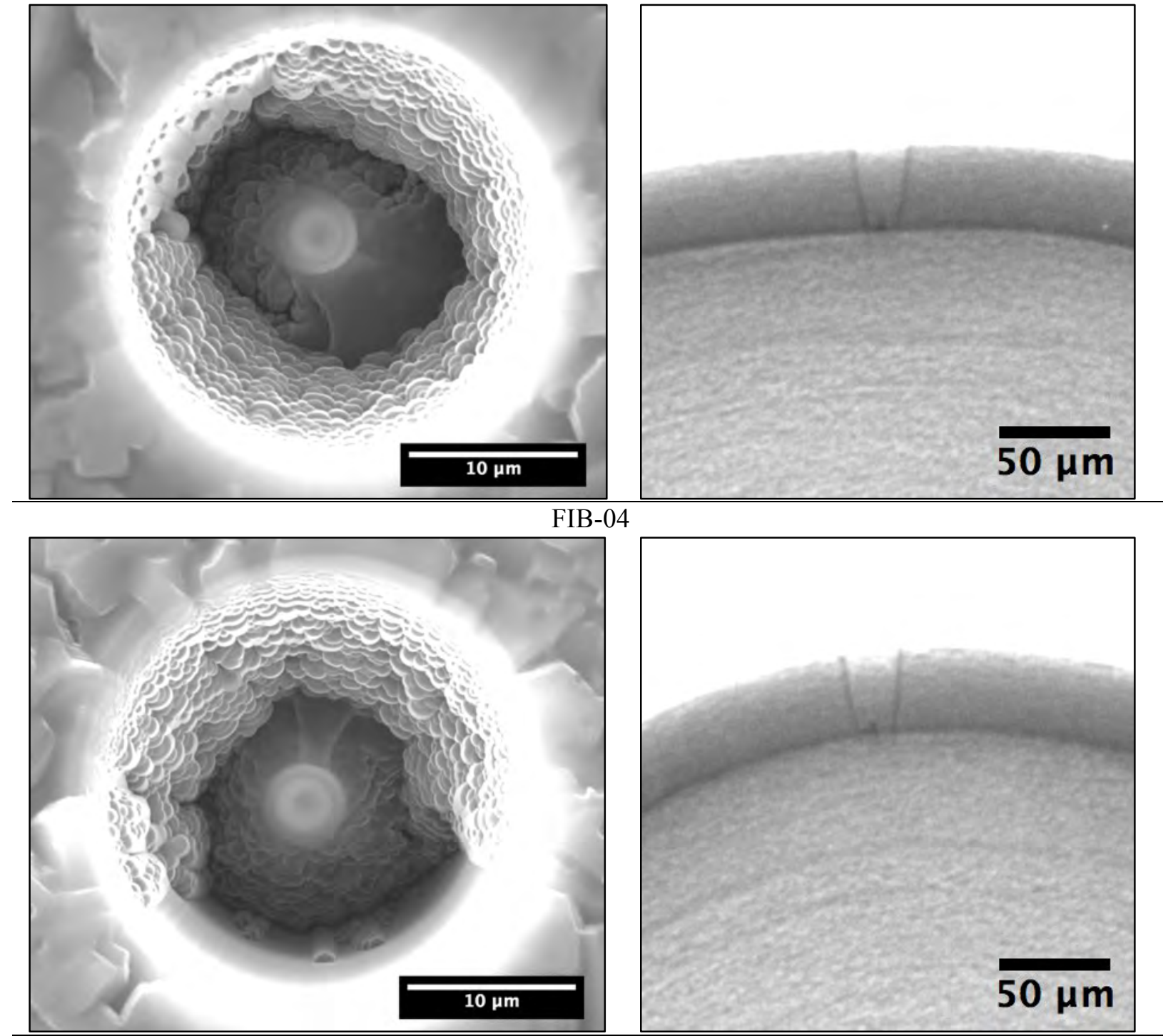

FIB-05 
ORNL/TM-2015/722-R2
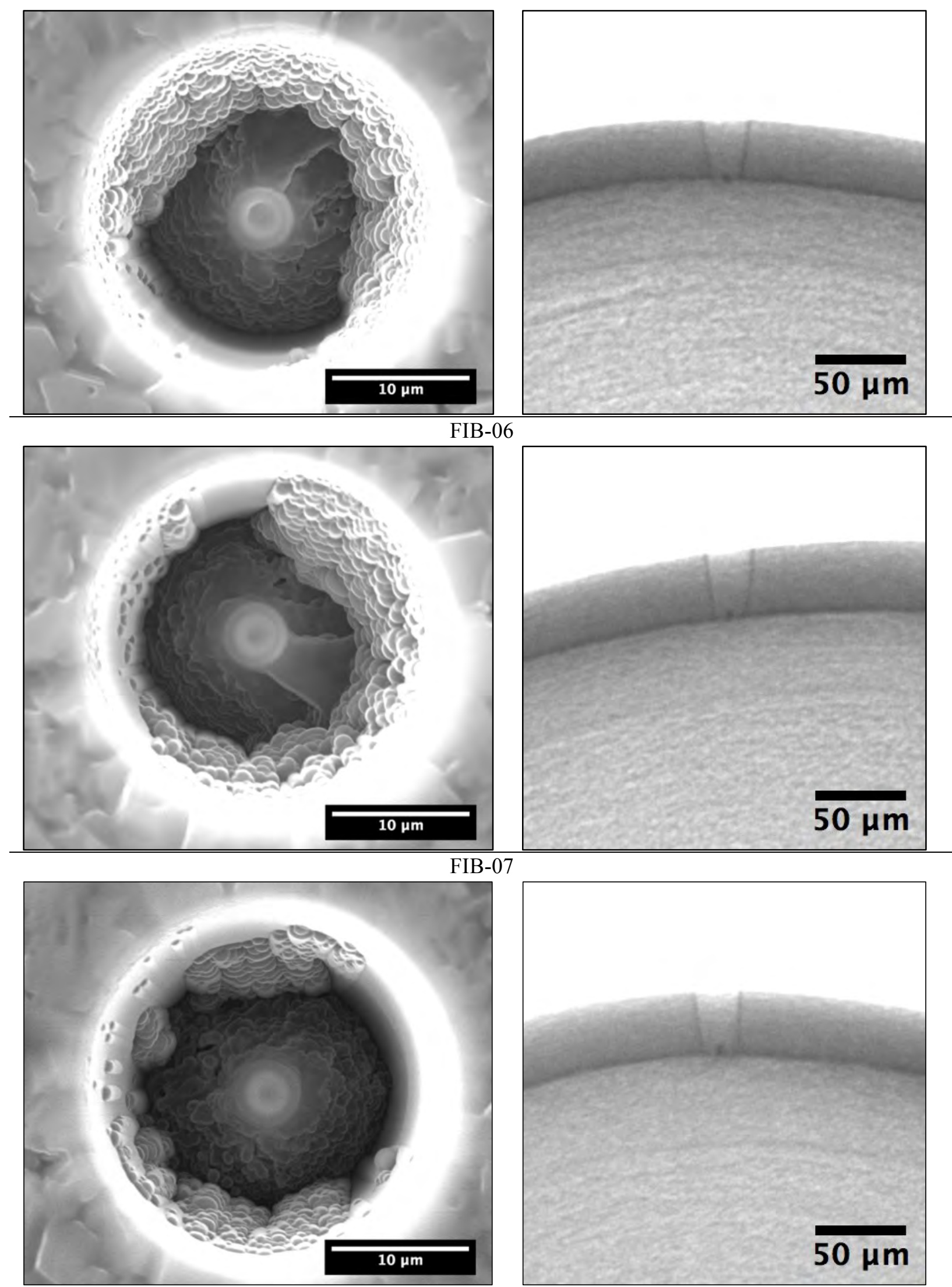

FIB-08 
ORNL/TM-2015/722-R2
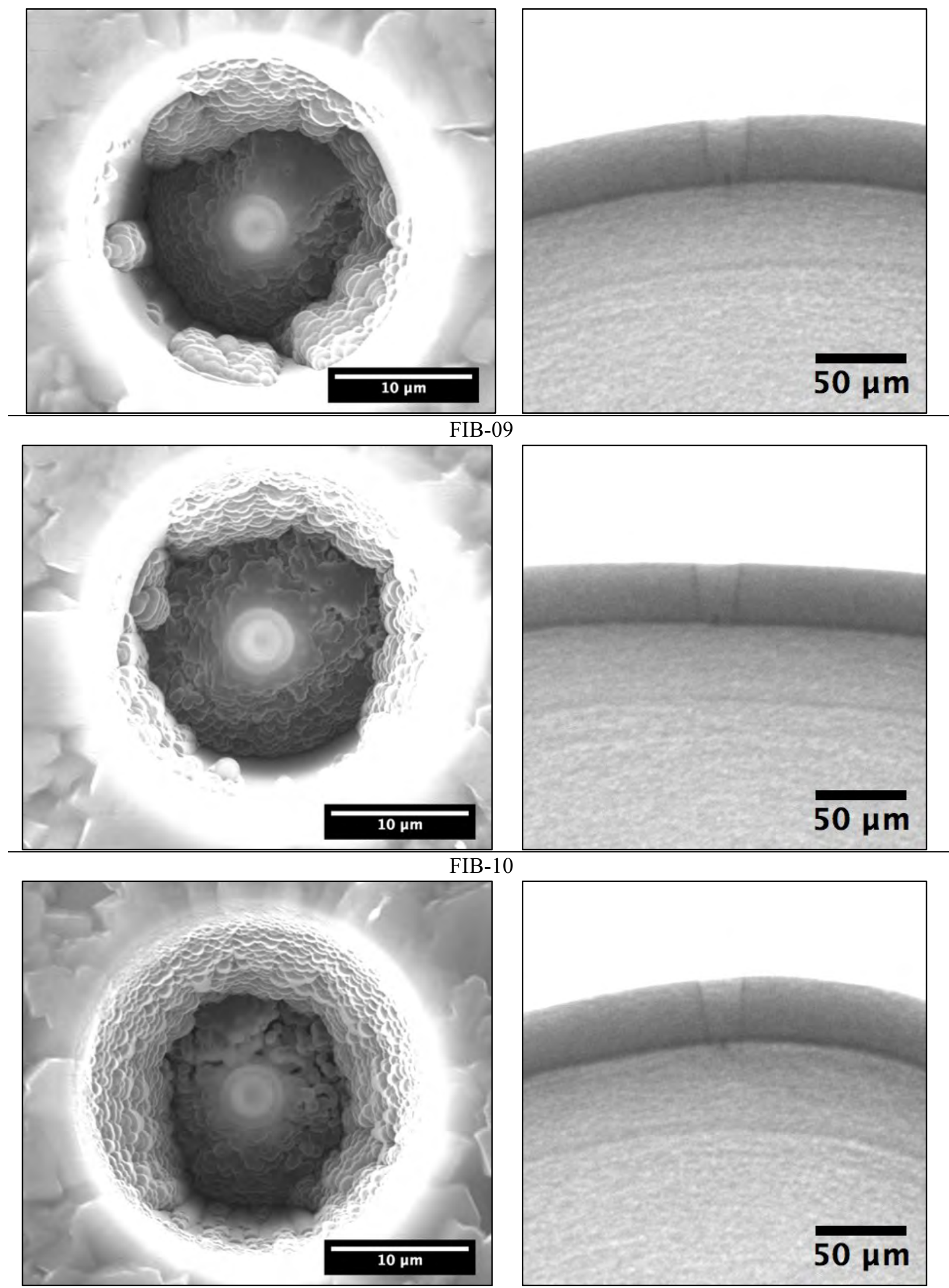

FIB-11 
ORNL/TM-2015/722-R2
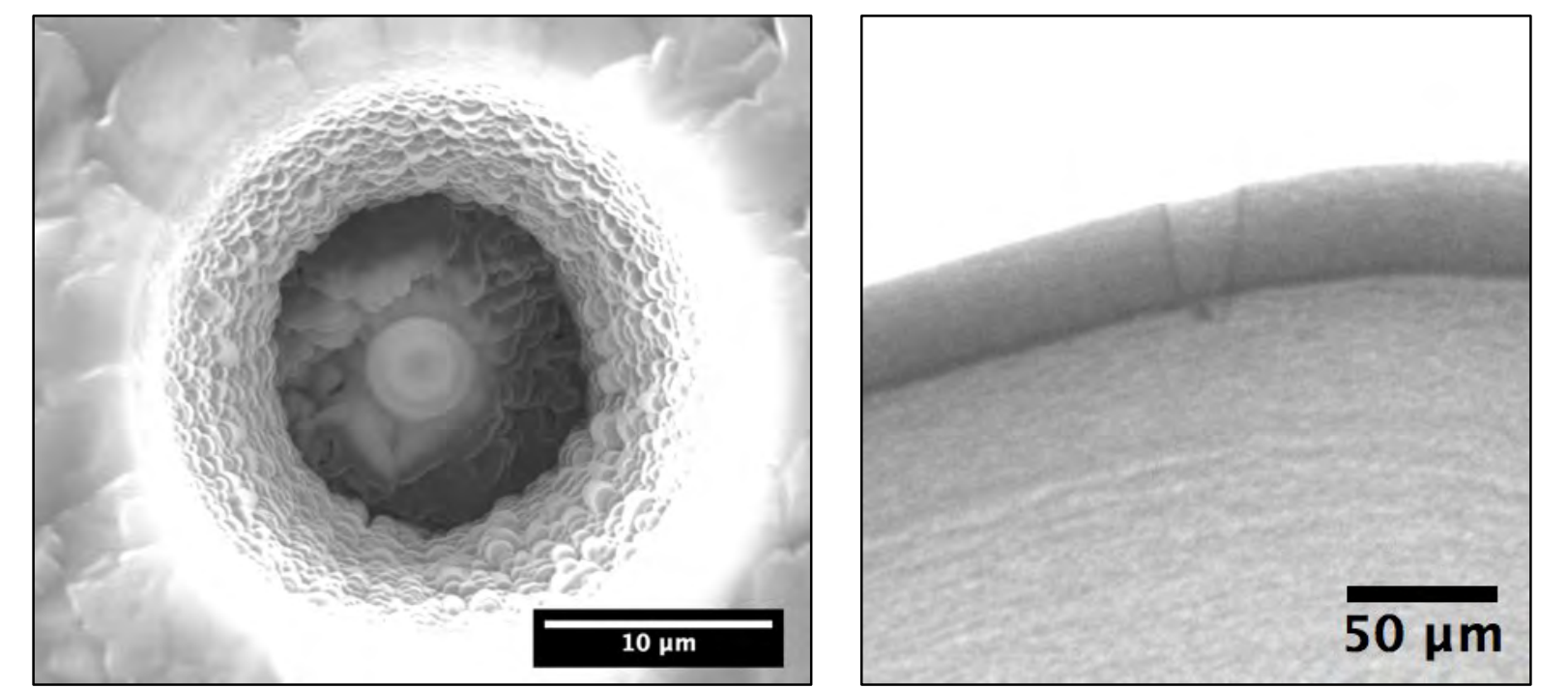

FIB-12
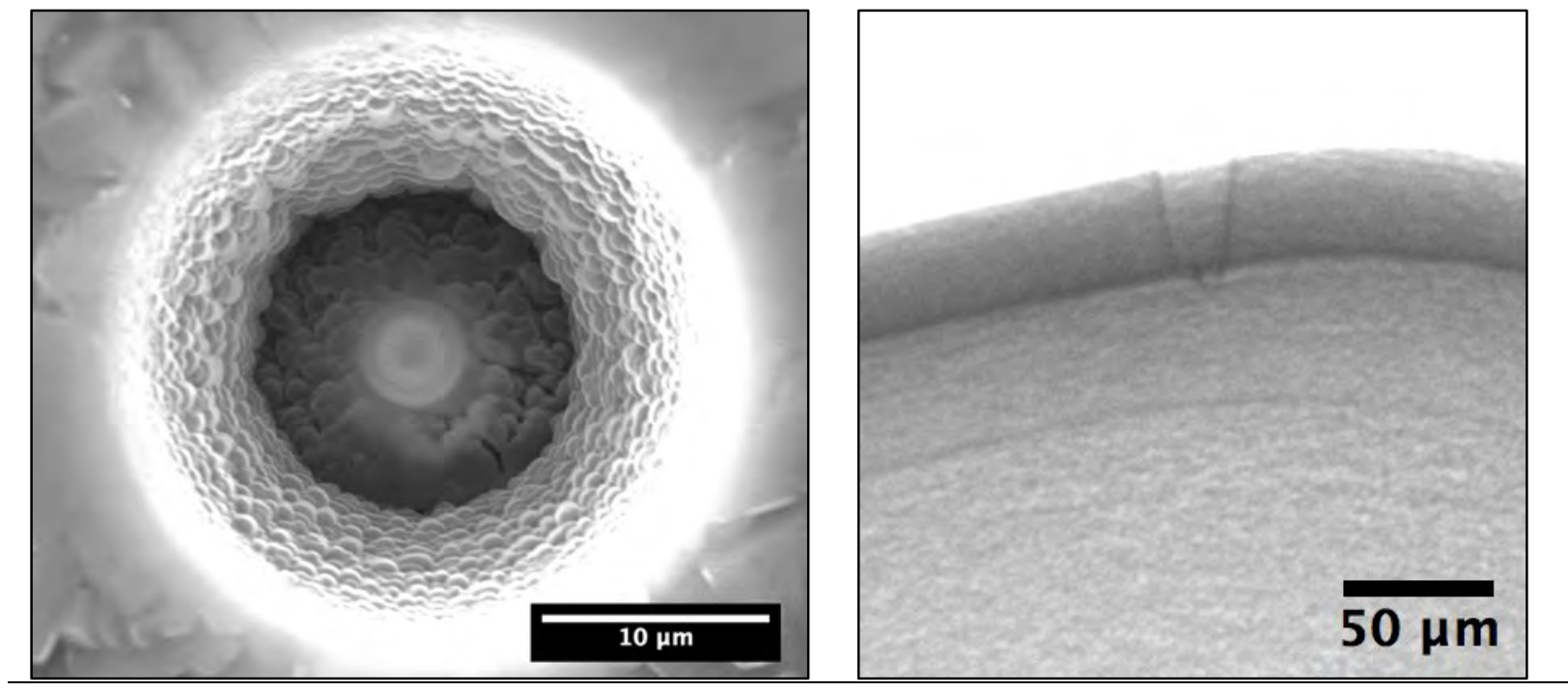

FIB-13
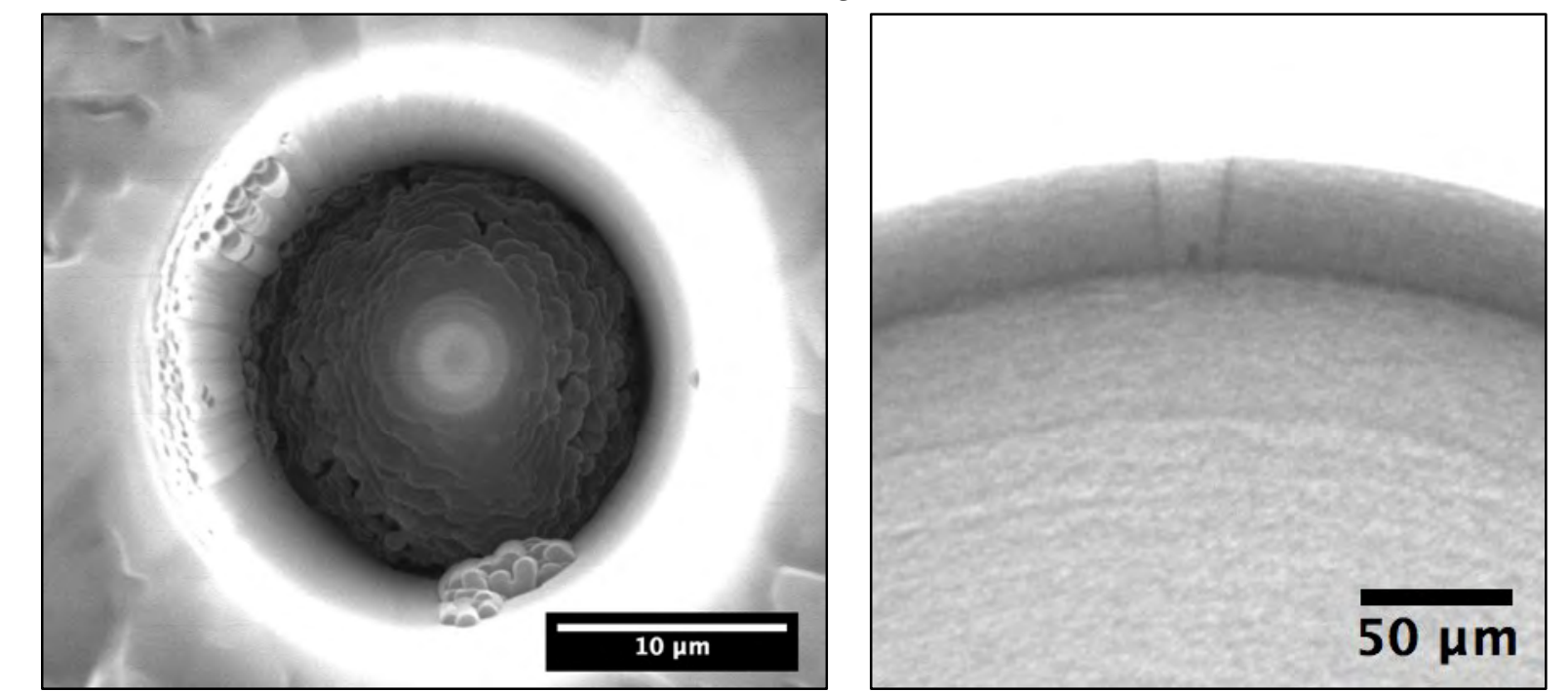

FIB-14 
ORNL/TM-2015/722-R2
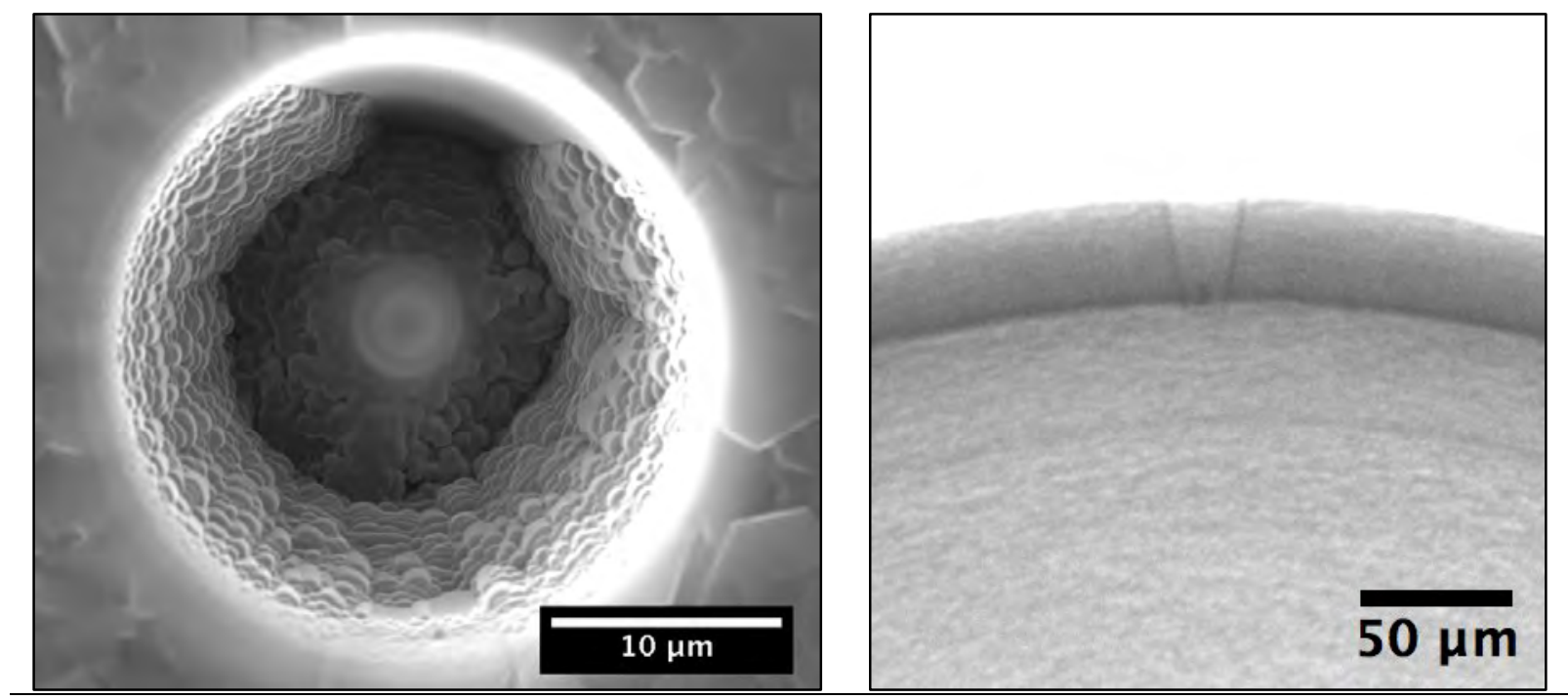

FIB-15
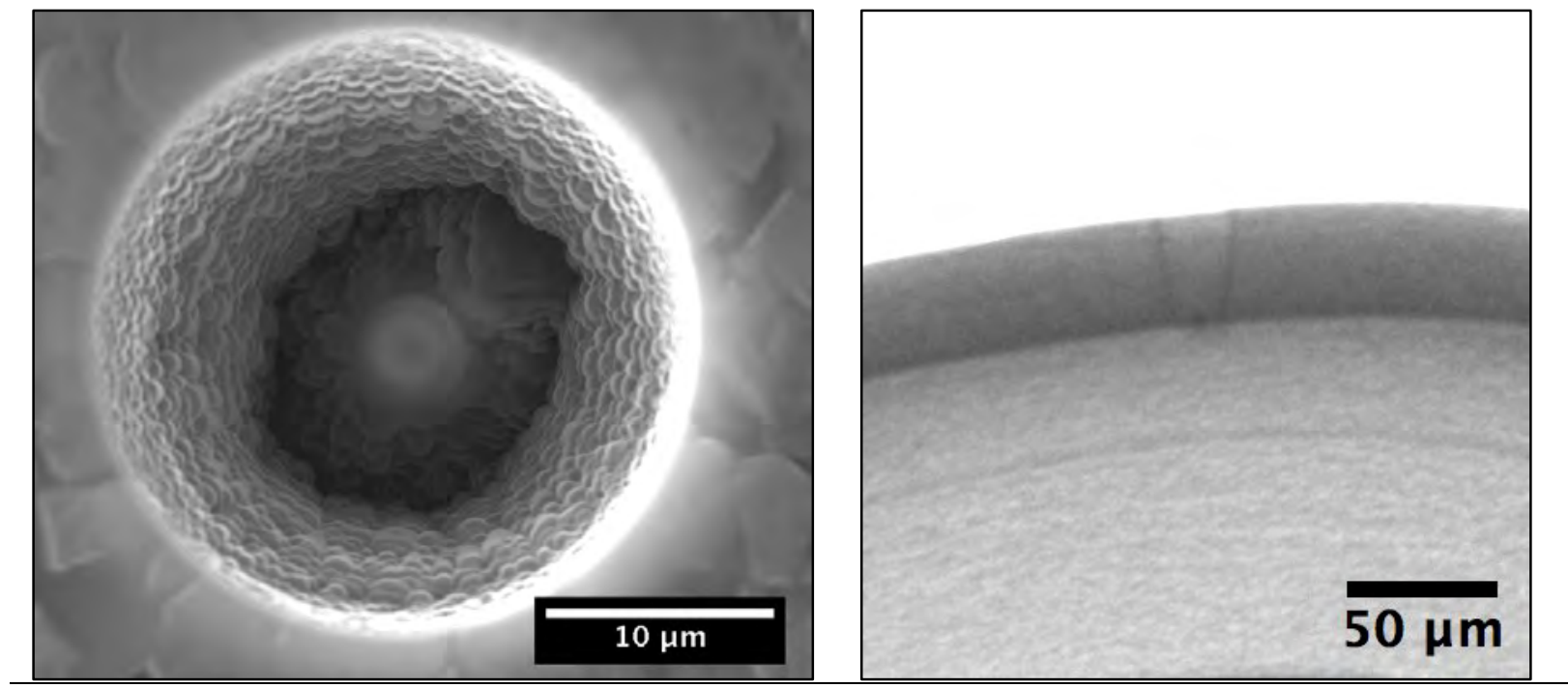

FIB-16
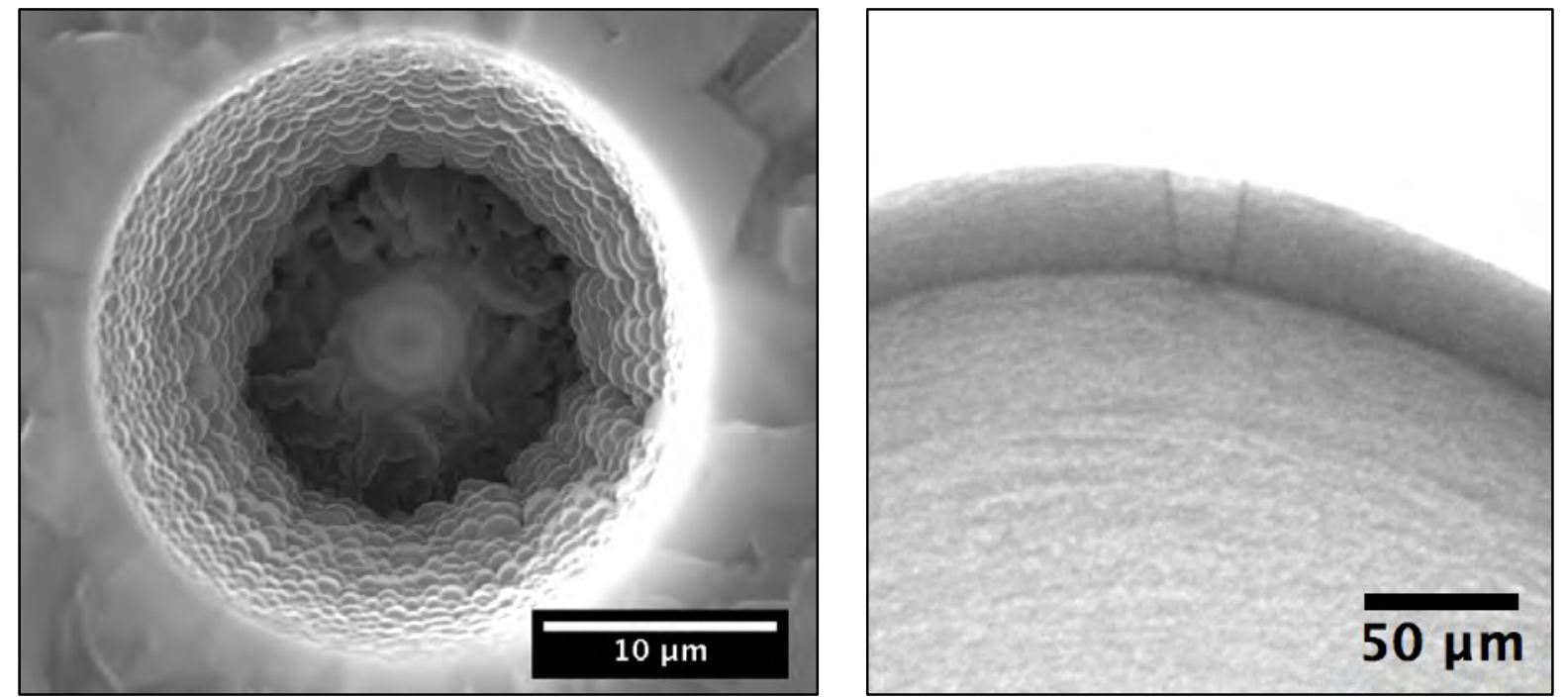

FIB-17 
ORNL/TM-2015/722-R2
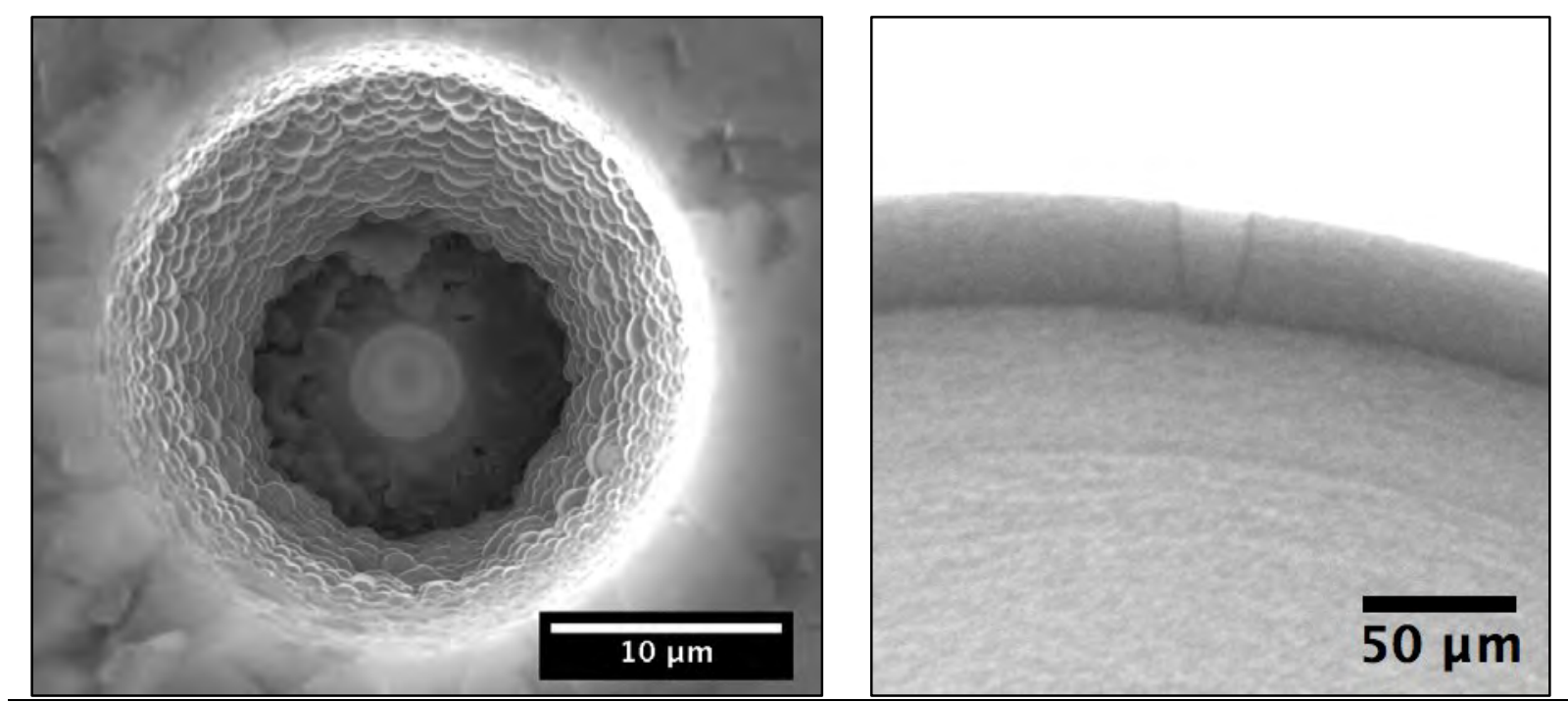

FIB-18
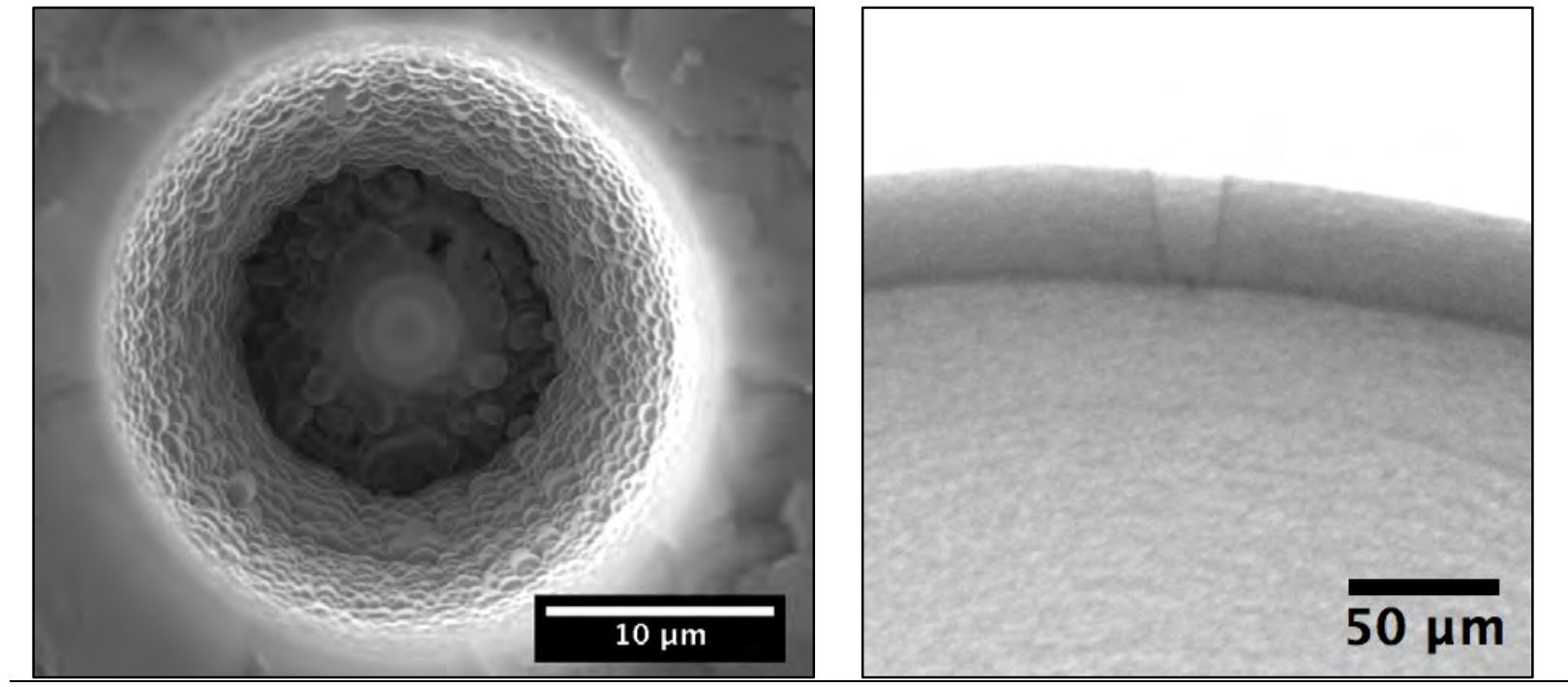

FIB-19
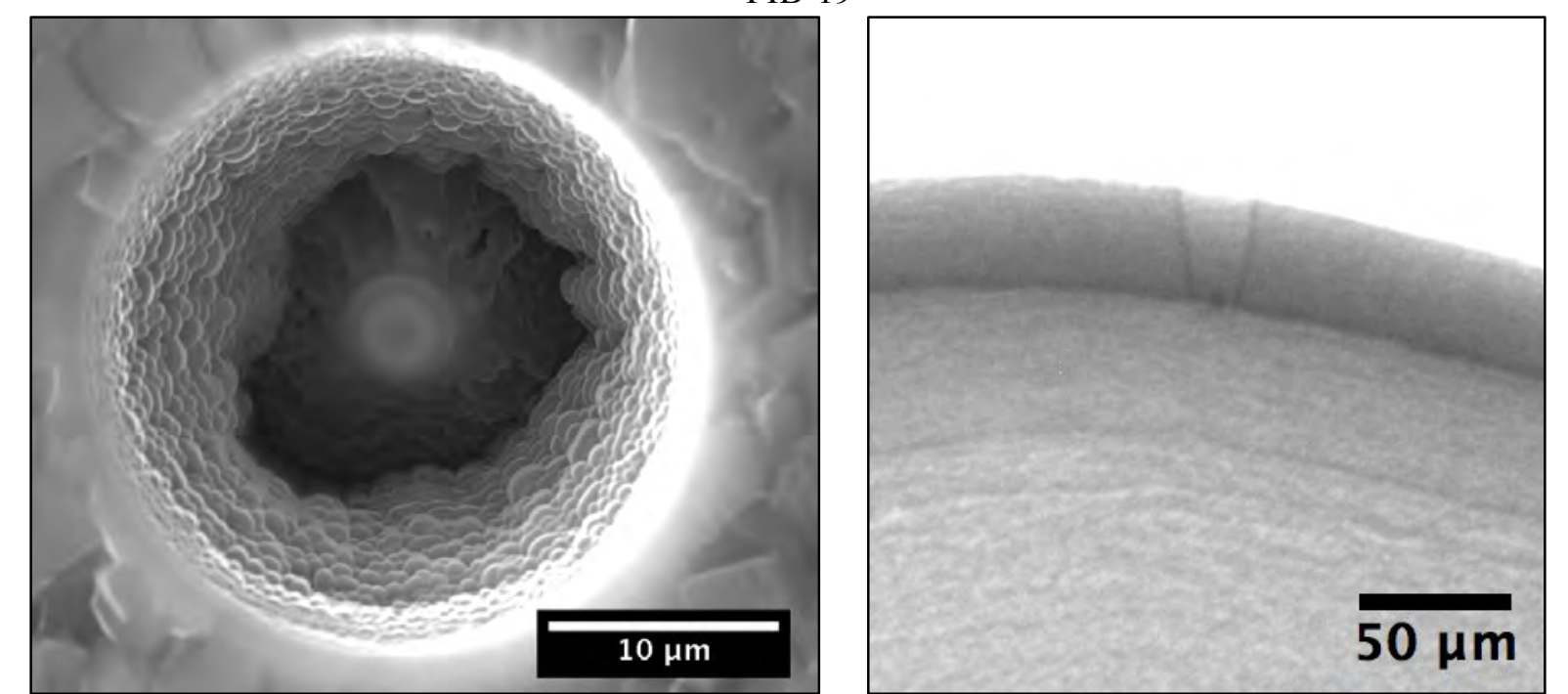

FIB-20 
ORNL/TM-2015/722-R2
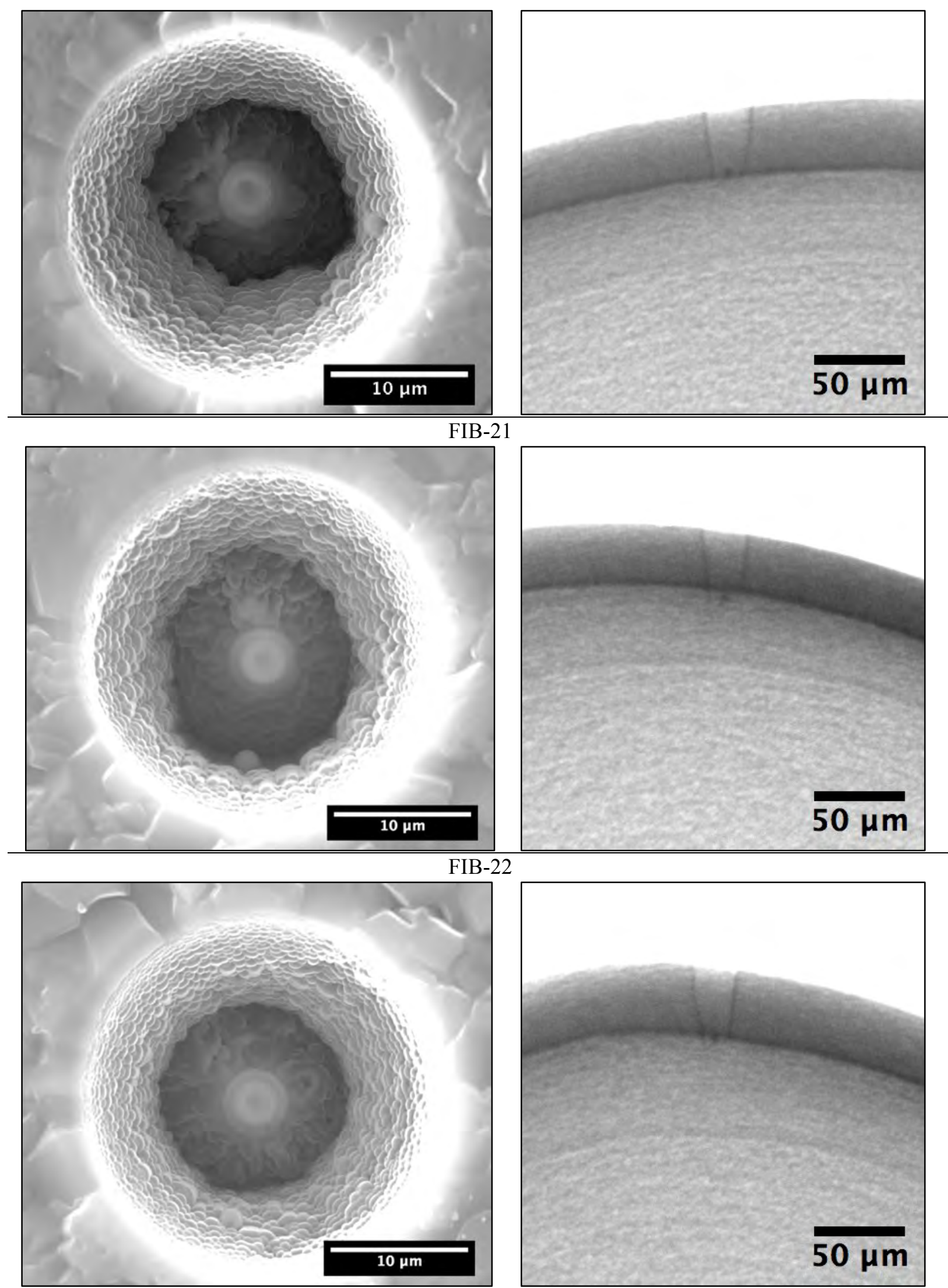

FIB-23 
ORNL/TM-2015/722-R2
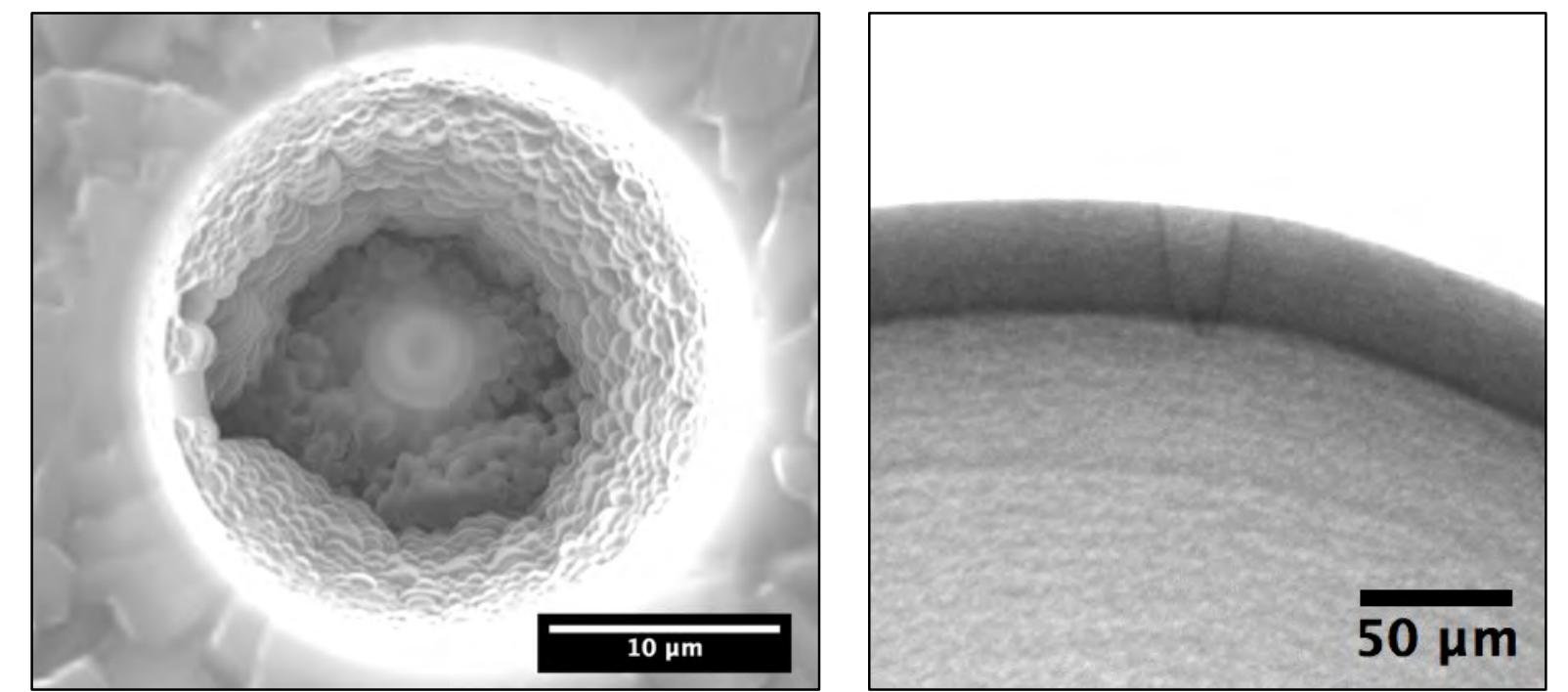

FIB-24
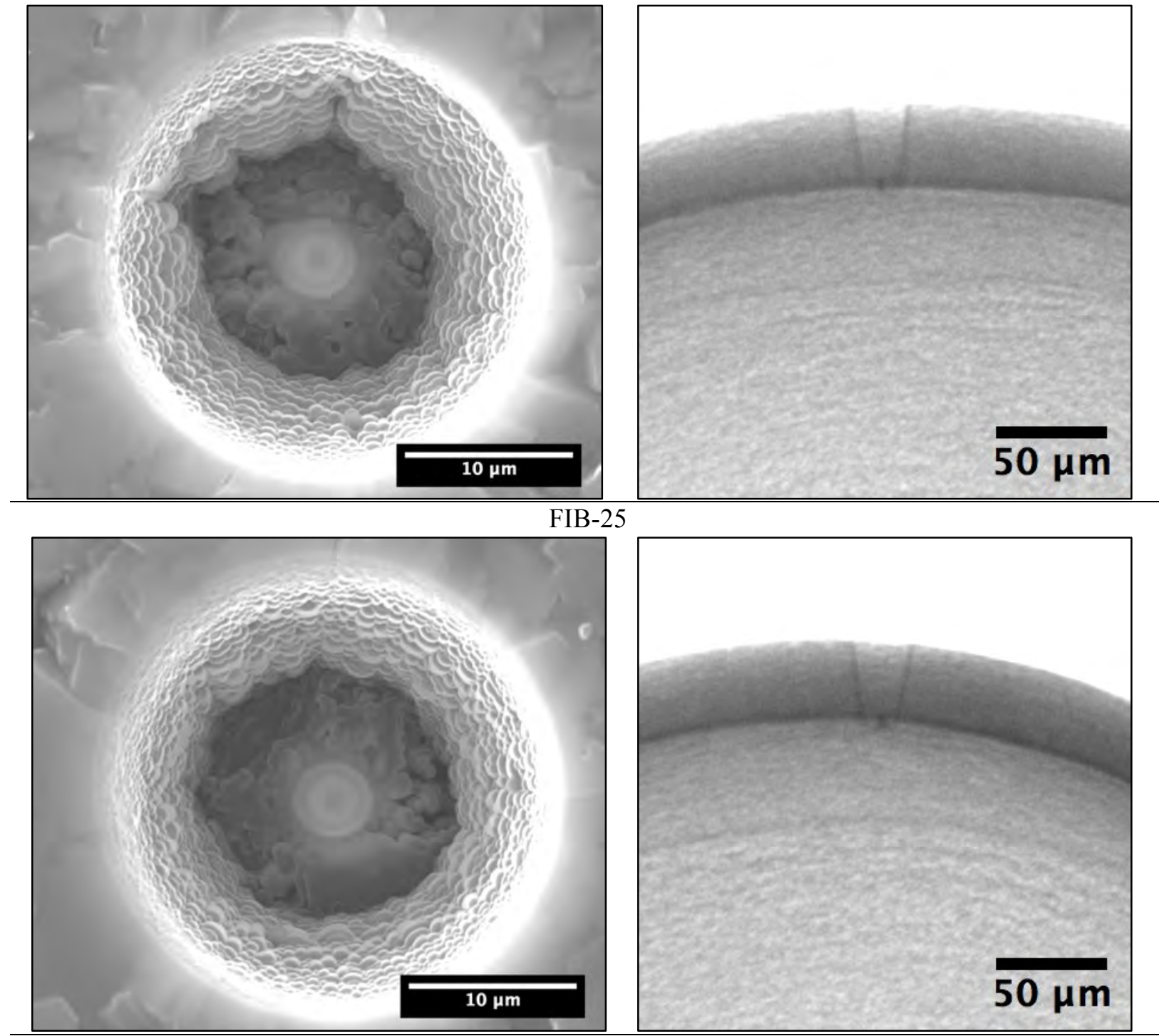

FIB-26 
ORNL/TM-2015/722-R2
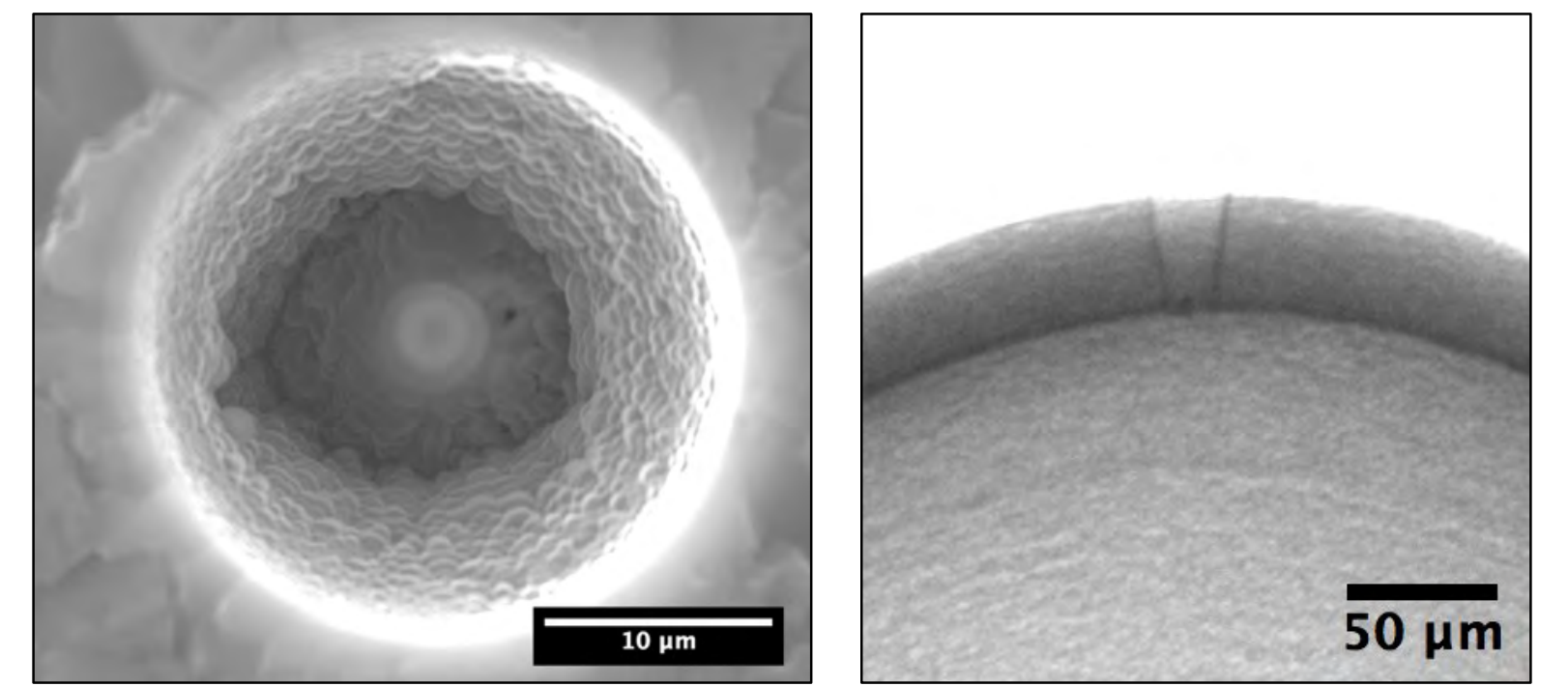

FIB-27
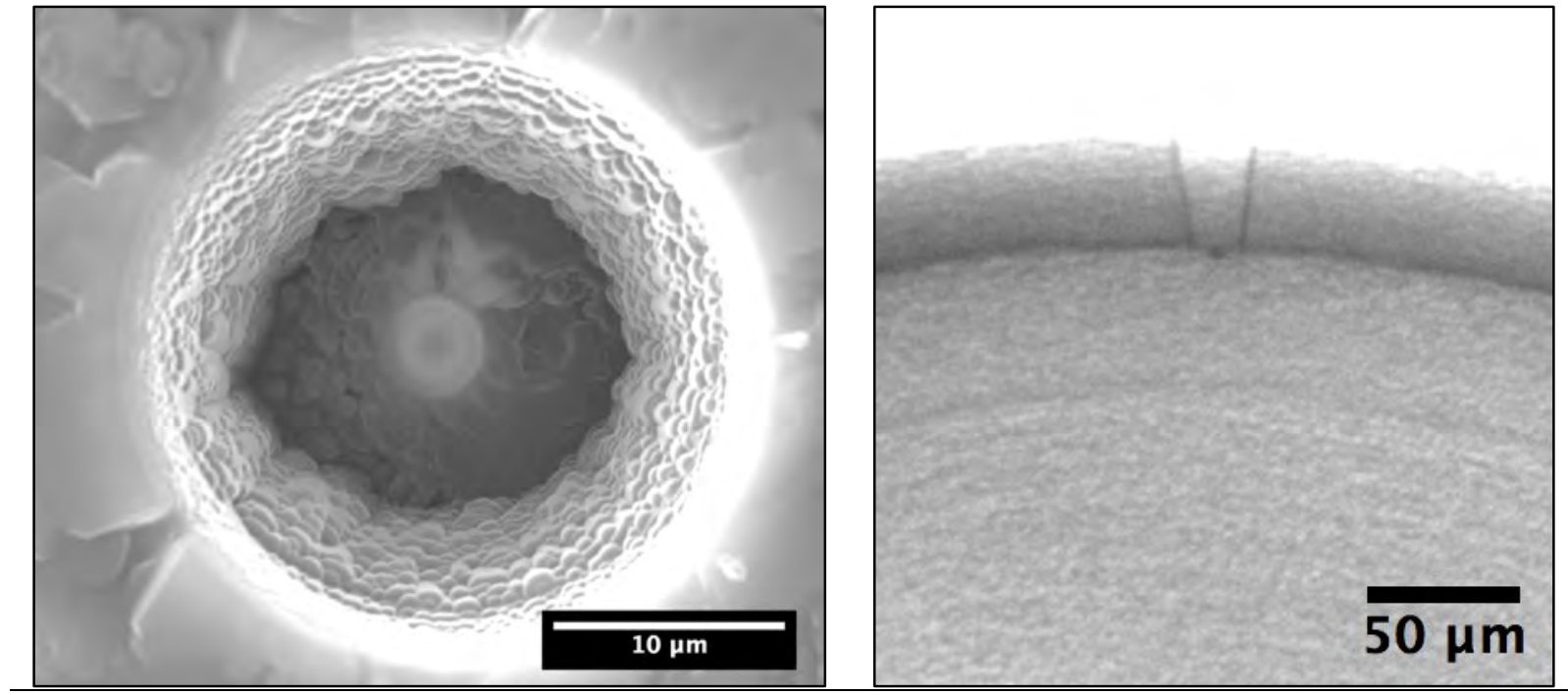

FIB-28 